Invasive Species in an Alvar Ecosystem: A soil seed bank study and insitu vegetation surveys studying the effects of Euphorbia cyparissias on the Burnt Lands Nature Reserve

by

Teresa Lynn Riley

\begin{abstract}
A thesis submitted in conformity with the requirements for the degree of Master of Science

Graduate Department of Geography and Environmental Studies Carleton University
\end{abstract}

(C) Copyright by Teresa Lynn Riley, 2005. 


$\begin{array}{ll}\begin{array}{l}\text { Library and } \\ \text { Archives Canada }\end{array} & \begin{array}{l}\text { Bibliothèque et } \\ \text { Archives Canada }\end{array} \\ \begin{array}{l}\text { Published Heritage } \\ \text { Branch }\end{array} & \begin{array}{l}\text { Direction du } \\ \text { Patrimoine de l'édition }\end{array} \\ \begin{array}{l}\text { 395 Wellington Street } \\ \text { Ottawa ON K1A ON4 }\end{array} & \begin{array}{l}\text { 395, rue Wellington } \\ \text { Ottawa ON K1A ON4 } \\ \text { Canada }\end{array}\end{array}$

Your file Votre référence

ISBN: 0-494-00788-5

Ourfile Notre référence

ISBN: 0-494-00788-5

NOTICE:

The author has granted a nonexclusive license allowing Library and Archives Canada to reproduce, publish, archive, preserve, conserve, communicate to the public by telecommunication or on the Internet, loan, distribute and sell theses worldwide, for commercial or noncommercial purposes, in microform, paper, electronic and/or any other formats.

The author retains copyright ownership and moral rights in this thesis. Neither the thesis nor substantial extracts from it may be printed or otherwise reproduced without the author's permission.
AVIS:

L'auteur a accordé une licence non exclusive permettant à la Bibliothèque et Archives Canada de reproduire, publier, archiver, sauvegarder, conserver, transmettre au public par télécommunication ou par l'Internet, prêter, distribuer et vendre des thèses partout dans le monde, à des fins commerciales ou autres, sur support microforme, papier, électronique et/ou autres formats.

L'auteur conserve la propriété du droit d'auteur et des droits moraux qui protège cette thèse. $\mathrm{Ni}$ la thèse ni des extraits substantiels de celle-ci ne doivent être imprimés ou autrement reproduits sans son autorisation.
In compliance with the Canadian

Privacy Act some supporting forms may have been removed from this thesis.

While these forms may be included in the document page count, their removal does not represent any loss of content from the thesis.
Conformément à la loi canadienne sur la protection de la vie privée, quelques formulaires secondaires ont été enlevés de cette thèse.

Bien que ces formulaires aient inclus dans la pagination, il n'y aura aucun contenu manquant.

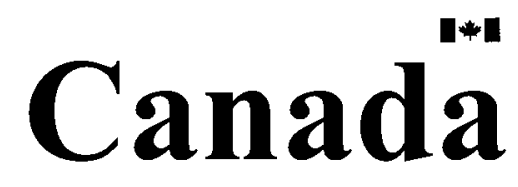




\begin{abstract}
In-situ vegetation surveys and a greenhouse soil seed bank study were conducted on the Burnt Lands Nature Reserve alvar located in Almonte, Ontario. The purpose of this study was to assess the effects of invasive alien plant species, particularly Euphorbia cyparissias, on native alvar plant communities in both the surface vegetation and at the soil seed bank level. Sixty plots were established randomly where vegetation surveys were conducted and soil samples were collected for the soil seed bank study. Spearman's Rank correlation analyses were applied to the percent crown closure of Euphorbia cyparissias in relation to soil depth, soil type, nutrient levels, above ground plant diversity and soil seed bank diversity. Results showed no statistically significant relations between measured variables and the presence or absence of Euphorbia cyparissias in the field.
\end{abstract}




\section{Acknowledgements}

First and foremost, I would like to thank both of my supervisors Dr. Céline Boutin and Dr. Ken Torrance for their unique contributions. Both supervisors provided support during phases of my research and their time and guidance was appreciated. I would also like to thank Dr. Chris Burn, a member of my supervisory committee, who provided direction as needed. A special thank you to Hazel Anderson who is always willing to help and make the life of a grad student a little easier; I would have been lost without her.

Don Cuddy, a taxonomy wizard, assisted this research by helping to identify numerous plant species in the field and laboratory. His advice and expertise about plants and the Burnt Lands Nature Reserve was paramount. Corina Bradshaw from the OMNR provided maps and species records as well as granted permission to conduct research on the Burnt Lands Nature Reserve. Mike Fox provided assistance with statistics and his time was greatly appreciated. Thank you to Gilles Bechdolff who was both a field and laboratory assistant, and Lisa Benedetto who helped collect the soils for the soil seed bank study despite the abundance of poison ivy!

Finally, I would like to thank my husband Chris; without his support this academic endeavour would not have been possible. 


\section{Dedication}

This thesis is dedicated to my daughter Kiara who reminds me every day what is really important in life. 


\section{TABLE OF CONTENTS}

Abstract $\quad$ ii

Acknowledgements

Dedication iv

Table of Contents $\quad$ V

List of Tables vii

List of Figures viii

List of Appendices $\quad$ ix

1. INTRODUCTION 1

1.1 Thesis Statement and Objectives $\quad 4$

1.2 Research Objectives

2. LITERATURE REVIEW $\quad 6$

2.1. Terminologies Defined 6

2.2 Invasive Alien Plant Species 7

2.2.1 Physiology and Life History of Invasive Alien Species 9

2.2.2 Ecosystem Susceptibility 11

2.3 Soil Seed Bank Studies 15

2.4 Alvar Ecosystems $\quad 20$

2.5.The Burnt Lands Nature Reserve 22

2.6 Alvar Soil Seed Bank Studies $\quad 27$

2.7 Euphorbia cyparissias as a Target Species $\quad 28$ 


\section{TABLE OF CONTENTS (Continued)}

3. METHODOLOGY 32

3.1 Visual Reconnaissance and Site Selection 32

3.2 Site Layout 33

3.3 Sampling $\quad 35$

3.4 Soil Seedbank Study 36

3.5 Vegetation Survey 38

3.6 Soil Analysis $\quad 39$

3.7 Statistical Analysis 39

4. RESULTS \& DISCUSSION

4.1 Crown Closure of Euphorbia cyparissias $\quad 42$

4.2 Species Composition 43

4.3 Soil Analysis $\quad 52$

4.4 Soil Depth 54

4.5 Trees and Shrubs $\quad 55$

5. SYNTHESIS \& CONCLUSIONS $\quad \mathbf{5 7}$

5.1 Limitations $\quad 69$

5.2 Future Research $\quad 70$

WORKS CITED 72 


\section{List of Tables}

Table 1: Baker's List 10

Table 2: Alvar community type classifications $\quad 21$

Table 3: List of significant plants present on the Burnt Lands Nature Reserve $\quad 26$

Table 4: Soil analysis - parameters and units $\quad \mathbf{4 0}$

Table 5: Species composition in the soil seed bank study and vegetation survey 44

Table 6: Species origin and growth pattern $\quad 46$

Table 7: Table of Spearman's Correlation $\quad \mathbf{5 0}$

Table 8: Results of the analysed soil parameters by plot $\mathbf{5 3}$ 


\section{List of Figures}

Figure 1: Map showing town of Almonte in relation to Ottawa, Ontario.

Figure 2: Map of Burnt Lands Nature Reserve.

Figure 3: Artist sketch of Euphorbia cyparissias.

Figure 4: Aerial photograph of the Burnt Lands Nature Reserve showing the selected research site.

Figure 5: Histogram showing the distribution of Euphorbia cyparissias as per cent crown closure.

Figure 6: Comparison of species by plot between the soil seed bank study and the vegetation survey.

Figure 7: Distribution of alien species in the soil seed bank study and the vegetation survey.

Figure 8: Histogram showing the distribution of soil depth. 


\section{List of Appendices}

Appendix A: Distribution of Measured Variables $\quad 80$

Appendix B: Per cent Crown Closure of Euphorbia cyparissias, $2004 \quad \mathbf{8 3}$

Appendix C: Soil Seed Bank Study Results $\quad \mathbf{8 4}$

$\begin{array}{ll}\text { Appendix D: Vegetation Survey Results } & 98\end{array}$

Appendix E: Number of Species by Plot in the Vegetation Survey and in the Soil Seed Bank Study

Appendix F: Soil Depth by Plot

106 


\section{INTRODUCTION}

Invasive plant species are plants that, if introduced into a natural area, reproduce so aggressively that native vegetation, unable to compete, is displaced (White et al., 1993; Haber, 2002). These aggressive plant invaders are able to alter significantly the invaded natural ecosystem by reducing the amount of light, water, nutrients and space available for native species, and by changing hydrological patterns, soil chemistry, moistureholding capacity, and fire regimes. The damage caused by invasive plants to native plant communities and biodiversity in natural ecosystems is so extensive that these invaders are reported to be the second leading cause of natural habitat destruction in North America (Hobbs \& Humphries, 1995; APWG, 1999; Lonsdale, 1999; With, 2001). Indeed, few if any regions in the world are exempt from the negative impacts posed by invasive plant species (Lonsdale, 1999; Alendorf \& Lundquist, 2003).

Since the 1950s, attempts at developing predictive models have been made for the determination of which alien species are likely to become successful invaders (Elton, 1958; Mooney \& Drake, 1986; Rejmanek \& Richardson, 1996; Allendorf \& Lundquist, 2003) and alternatively, which ecosystems are likely to be susceptible targets for invasion (Swincer, 1986; Groves \& DiCastri, 1991; Goodwin et al., 1999; Lonsdale, 1999).

Unfortunately, these endeavours have been largely unsuccessful. One of the reasons is a lack of empirical evidence from which to build and test the strength of predictive models (Perrins et al., 1993). 
Although the full extent of their utility is still a topic of debate, studies that focus on individual species and their functional role within a specific ecosystem can render valuable information to the understanding of a particular invader. The study of one species in a specific ecosystem can reduce the complexity of ecosystem studies for the purpose of understanding specific aspects of a particular invader and how it operates within an ecosystem. Such investigations can complement holistic studies, which focus on communities and their multiple inter-relations to biotic and abiotic factors, by providing insight that may act as a foundation for expanding the several existing hypotheses on the success of alien invasive species.

One area of invasive species research that has received little attention is the study of the soil seed bank in relation to invasive alien species. The primary means of reproduction for plant species is through the dispersal of seeds from the parent plant and it is known that many plant species produce seeds that maintain their viability in the soil seed bank for several years (Leck et al., 1989). Although a vast literature on seed ecology and plant population biology exists, little is known about the effects that invasive plant species have on native seed abundance and viability.

Soil seed bank studies provide information about the types and viability of seeds present in, or absent from, the soil. Furthermore, soil seed bank studies can answer questions such as: Do the seeds of native plant communities persist in the soil seed bank given the presence of a particular invasive plant species? Are the seeds of native plants able to germinate under altered ecosystem conditions imposed by the invasive plant species? Do 
the native plant seeds remain viable and able to germinate if pre-invasion conditions are restored? If the latter were the case, a valuable source of native seeds would still be present in the soil. Such knowledge concerning seed viability in the soil seed bank could be significant for restoration ecologists who are struggling to find appropriate tools to assess and manage the effects of invasive plant species. Restoration, loosely defined as returning an ecosystem to a prior state for the purpose of preserving or maintaining native species is necessary if ecologists are to conserve native plant communities that are threatened by invasive plant species (Bradshaw, 1997; Gilbert \& Anderson, 1998; Rana, 1998; Holloway, 2000; Throop, 2000). Today, most restoration ecology techniques related to invasive plant species control are applied in an ad hoc manner or use a 'wait and see' approach due to a lack of type-specific ecosystem models. Understanding how an ecosystem operates and how an invasive alien species interacts within that ecosystem need to be understood before restoration techniques are applied. A soil seed bank study designed to test the effects of a particular invader within a particular ecosystem could serve as the foundation for such a model.

This research project was conducted at the Burnt Lands Nature Reserve [See Figure 1], an alvar ecosystem that is listed as an Area of Natural Scientific Interest (ANSI) by the Nature Conservancy of Canada. Alvar ecosystems are globally rare and the Burnt Lands is cited as the largest and best example of this ecosystem type in North America (Brownell \& Riley, 2000). For these reasons, the long-term viability of vegetative communities on this site is a priority for the Ministry of Natural Resources in Ontario. Several invasive alien species are already present in this nature reserve but they do not 
appear to be seriously threatening native plant communities at this time. A variety of buckthorn (Rhamnus spp.), purple loosestrife (Lythrum salicaria) and cypress spurge (Euphorbia cyparissias) are among the invaders that have the potential to become serious threats to the native plant communities. An assessment of the vegetative community and the soil seed bank in an area of the Burnt Lands Nature Reserve where one of these invaders is present may provide insight into future impacts that the invader may have on this ecosystem.

\subsection{Thesis Statement and Objectives}

This thesis will examine the effects of cypress spurge (Euphorbia cyparissias) on native plant communities in an alvar ecosystem (Burnt Lands Nature Reserve) using vegetative surveys, a soil seed bank study and soil analysis. The purpose is to further the understanding of the impacts that invasive plant species pose on natural ecosystems and their soil seed banks, with specific applicability to alvars and to Euphorbia cyparissias as an invasive alien species.

\subsection{Research Objectives}

The objectives of this research are:

1. To determine if native plant communities in natural alvar ecosystems can persist in the soil seed bank in the presence of Euphorbia cyparissias by conducting a soil seed bank study; 
2. To investigate the relation between the above ground vegetation at the Burnt Lands Nature Reserve and the germination results of the soil seed bank study by comparing Euphorbia cyparissias in an in-situ vegetation survey to the species that germinate in the soil seed bank study in the same plot; and

3. To detect significant relations by the use of Spearman's Rank correlation analysis between the presence of Euphorbia cyparissias in plots and measured values of species richness, number of invasive species, number of native species, soil depth and soil nutrients. 


\title{
2. LITERATURE REVIEW
}

\subsection{Terminologies Defined}

Universally accepted definitions of alien species, invasive species and weeds have not permeated current literature and the use of these terms often overlap or imply entirely different meanings. Given this tendency towards non-uniform terminology, these terms are defined for use in this study based on a compilation of definitions derived from the broad literature on alien invasive species, and are not attributed to any one author.

\begin{abstract}
Alien Plant Species
Alien plants are species that did not naturally evolve in the ecosystem or region in which they currently reside. The majority of alien plants in Canada come from northern European nations and were introduced in the 1800 s by European settlers. Other species have come from Asia and Northern Africa where climates are similar to those of their host environments in North America.
\end{abstract}

\section{Invasive Plant Species}

The majority of invasive plant species are also alien species that have been accidentally or intentionally introduced by humans for various cultivation purposes but have escaped their intended boundaries and successfully colonised natural ecosystems. Invasive species aggressively compete with native vegetation, reproduce rapidly and have the ability to form pure stands that, in severe cases, displace native plant species and alter the functioning of natural ecosystems. 


\section{Weeds}

Weeds are species that can be both alien and invasive but tend to colonise highly disturbed areas such as roadsides, old fields, pasture lands, gardens and agricultural areas. The term weed is mainly used in reference to unwanted species that grow in cultivated areas and are considered pests because of their tendency to be invasive or to harbour harmful attributes that affect livestock or crops. Weeds are primarily defined by their undesirability. Some native species, such as Asclepias syriaca, are also classified as weeds in some provinces and in the United States. The principal difference between a weed and an invasive species is that weeds tend to colonise highly disturbed areas but generally do not invade intact natural ecosystems.

\subsection{Invasive Alien Plant Species}

Alien plants are species that have been intentionally or accidentally introduced into an ecosystem in which they did not naturally evolve (Cronk \& Fuller, 1995; McNeely et al., 2001; Scudder, 2002). The vast majority of alien plant species are intentionally introduced for human economic or social benefits. Most of these species have minor impacts on the natural ecosystems because they rarely establish themselves beyond their intended cultivation boundaries (Heffernan, 1998; Primack, 1993).

Haber (2002) estimates that out of Canada's 4200 identified vascular plants, approximately 27 per cent (1134) are alien. Six per cent (68) of these alien species are known invasive species (Haber, 2002). Invasive alien species (IAS) are species that have 
escaped their intended bounds and successfully colonised natural areas in such abundance that they have significantly altered or impaired natural ecosystem functioning (Barrett \& Richardson, 1996; Cronk \& Fuller, 1995; Heffernan, 1998; Scudder, 2002). IAS have the ability to alter ecosystems by reducing light, water, nutrients and space available for native species. IAS also have the ability to change hydrological patterns, soil chemistries, moisture-holding capacities, fire regimes, as well as to reduce biodiversity and introduce diseases harmful to native species (Hobbs \& Humphries, 1995; Gordon, 1998; Heffernan, 1998; Higgens et al, 1999; McNeely et al., 2001; Evans, 2003). The impacts of IAS are enormous. It is estimated that within the United States 138 billion dollars are spent each year to control or eradicate IAS (Evans, 2003). This figure only accounts for areas where they pose an economic problem for humans, such as farming (Evans, 2003).

Due to the harmful effects imposed on natural areas by IAS, the goals of research investigating them are to predict their introduction, their likelihood of spread and the amount of damage that a given species may cause in a particular ecosystem. Scientists believe that if they are able to predict such occurrences, they will be better able to successfully manage or eradicate these invaders. Researchers have focused primarily on two popular areas pertaining to the study of IAS: the physiology of invasive plant species, and ecosystem susceptibility. 


\subsubsection{Physiology and Life History of Invasive Alien Species}

If the life history and physical properties of a plant are adequately understood, there is a possibility of isolating and identifying the attributes that make a species an invader (Hobbs \& Humphries, 1995; Newsome \& Noble, 1986; Luken, 1997; Rejmanek \& Richarson, 1996; Goodwin et al; 1999; McNeely et al., 2001). Not all alien plants are invasive; therefore, it has been hypothesised that IAS contain unique traits that are absent in non-invasive species.

In 1965, Baker, a pioneer in the field of invasive species, developed a list that identified the characteristics believed to be common amongst invading species [Table 1]. This list was designed as a guideline for assessing the likelihood of a particular species becoming an invader. Newsome \& Noble (1986) refer to Baker's list as a "wish list" because no one species is likely to possess all 14 characteristics. Moreover, if a plant does possess one or more of the identified characteristics, this does not imply that the species is in fact an invader. Perrins et al. (1993) tested Baker's list by applying it to a field study of introduced Impatiens in the British Isles. In this study, forty-nine British annuals were scored against Baker's list. The results showed that the most invasive species contained only two of Baker's characteristics while individual native species possessed ten or more. Many of the characteristics on Baker's list do apply to invasive species, although the general nature of such characteristics allows them to be applied to most plant species invasive or not. Baker's list is too general to have adequate predictive value for the 
Table 1: Baker's List

\section{Characteristics for an Ideal Weed*}

1. Has no special environmental requirement for germination.

2. Has discontinuous germination (self-controlled) and great longevity of seed.

3. Shows rapid seedling growth.

4. Spends only a short period of time in the vegetative condition before beginning to flower.

5. Maintains a continuous seed production for as long as growing conditions permit.

6. Is self-compatible, but not obligatorily self-pollinated or apomictic

7. When cross-pollinated, this can be achieved by a non-specialised flower visitor or by wind.

8. Has very high seed output in favourable environmental circumstances.

9. Can produce some seed in a very wide range of environmental circumstances. Has high tolerance of climate and edaphic variation.

10. Have special adaptations for both long distance and short distance dispersal.

11. If a perennial, has vigorous vegetative reproduction.

12. If a perennial, has brittleness at the lower nodes of the rhizomes or root-stock.

13. If a perennial, shows an ability to regenerate from severed portions of the rootstock.

14. Has ability to compete by special means: rosette formations, choking growth, exocrine production (but no fouling of the soil for itself).

* In Baker's work, the use of the term 'weed' is used as a synonym for invasive species.

Source: Newsome \& Noble, 1986 
purpose of determining which species are likely to become successful invaders

(Newsome \& Noble, 1986; Perrins et al., 1993).

Attempts to expand upon Baker's work have yielded little or no success. Some scientists believe that individual plants must be studied more rigorously by discovering and understanding biological attributes that promote invasibility (Allendorf \& Lundquist, 2003). Others believe that the advancement of the field can be achieved by examining the ecosystem instead of isolating a single species. One such method is the study of ecosystem susceptibility, an approach that includes the study of plant communities, the state of the natural environment, presence and type of disturbance, climate, nutrient availability, and human presence (Hobbs \& Humphries, 1995; Lonsdale, 1999).

\subsubsection{Ecosystem Susceptibility}

Ecosystem susceptibility is the study of whether a certain type of ecosystem is more likely to be invaded due to abiotic, biotic or anthropogenic elements (Swincer, 1986; Wilson, 1990; Richardson \& Bond, 1991; Goodwin et al., 1999). The three leading hypotheses examined by proponents of ecosystem susceptibility are: the climatic conditions of the host environment must be similar to the native environment for the invasive plant species to survive; a high level of species richness hinders the invasion process; and disturbance facilitates invasion. 
Climate

Plants are naturally restricted to geographical regions because they are unable to cross major environmental barriers (Wilson, 1990). Even moderate climatic changes may cause extirpation or extinction of a species (Primack, 1993). Scientists are able to predict that invasive plant species are unlikely to persist outside of their climatic tolerance limits or to invade ecosystems that vary widely climatically from their native habitats (Swincer, 1986; Richardson \& Bond, 1991; Goodwin et al., 1999). Although climatic restrictions appear to be rudimentary when considering species range, the physical study of these variables is often more obscure. Temperature, wind, moisture and light are climatic variables that are easy to measure. However, there are complex interactions among these variables, such as the interactions between temperature and moisture, especially when coupled with the effects that these interactions impose on other processes such as nutrient dynamics in the soil. Interactions play a significant role in determining which plant communities thrive in a given area. Richardson \& Bond (1991) suggest that there are many elements that have yet to be investigated concerning climatic effects on vegetation. While climate may be a good predictor of invasive potential on a broad scale, we still know relatively little about the exact causes of why this is true.

\section{Species Richness Hypothesis}

The species richness hypothesis was derived from the classic notion that more diverse ecosystems are inherently more stable. Extrapolations from this once accepted truism suggest that as species richness increases, so does competition for available resources. Since the ecosystem is being taxed by the existing species, it is more difficult for an 
invasive species to successfully establish itself within that system. It has been argued that an invasive species would be more successful in an ecosystem with fewer species because the invader would be able to find a niche by making use of untapped resources in that ecosystem (Case, 1991; Fox \& Fox, 1986; Cronk \& Fuller, 1995; Richardson \& Bond, 1991; Swincer, 1986). While it has been shown that stability and diversity are not synonymous, the argument that more diverse ecosystems more successfully repel invaders continues to be debated

In his now classic book The Ecology of Invasions of Plants and Animals, Elton (1958) was the first to clearly state that species-rich communities resist invaders. Early rebuttals of this hypothesis were largely ignored due to the influence Elton held in this field of study. However, more recent examinations pose serious questions regarding the legitimacy of such a statement. The most extensive study has been performed by Lonsdale (1999) who collected data on the number of alien species, the number of native species, site area and the fraction of the total flora that was alien for 184 sites across the globe. He then performed various statistical analyses of these data and was unable to conclusively support the species richness hypothesis. While there were some cases where invasive species were less numerous in highly diverse ecosystems; the opposite was more common. The diversity of microclimates, habitat heterogeneity, and available nutrients are favourable to the invader in the same way that these elements are favourable to native species. Therefore, chances of colonisation success for the invader are the same as or greater than for the native flora (Levine \& D'Antonio, 1999; Lonsdale, 1999; McNeely, 2000). Furthermore, there are now several studies that show invasive species are serious 
threats to highly diverse ecosystems across the globe (Levine \& D'Antonio, 1999;

Lonsdale, 1999; McNeely et al, 2001). Lonsdale (1999) concluded that the only result that can be derived from the species richness hypothesis is that richer plant communities are evidence of greater habitat diversity.

\section{Disturbance}

Disturbance to an ecosystem, either anthropogenic or natural by, for example, fire, flooding, or simply the dying and replacement of species, is a necessary ingredient for the facilitation of invasion. This hypothesis is widely accepted with few opposing views. Anthropogenic disturbances to ecosystems are the most widely studied by ecologists in relation to invasive species. Invasive species tend to be greatest in ecosystems that have been severely impacted by humans. Activities such as clear-cutting, farming, urbanisation, human visitation, and the creation of roads all provide potential opportunities for invasive species (Fox \& Fox, 1986; Richardson \& Bond, 1991; Hobbs \& Huenneke, 1992; White et al, 1993; Luken, 1997; Woods, 1997).

Luken (1997) points out that although disturbance appears to be necessary in the preliminary stages of invasive species colonisation, scientists have a difficult time distinguishing the exact cause and effect relations. Human impacts tend to be so highly complex and multiform that determining the source of disturbance that resulted in the onset of invasion is troublesome. Furthermore, species vary in their response to disturbances, which also complicates the analysis. While invasive species do appear to favour highly disturbed sites, this observation has "little practical importance as all 
ecosystems experience some form of disturbance" (Perrins et al., 1993, p 43).

Disturbance is an important element in the invasion process; however, it needs to be better understood in order for it to have predictive value.

To date, these areas of inquiry, individually and collectively, have not yielded predictive indicators. Some scientists believe that the lack of progress in this is the result of ignoring important data, such as failed invasion attempts (Rejmanek \& Richardson, 1996). Other scientists believe that a holistic approach, which includes the examination of several interactive factors, as opposed to isolating attributes in the plant or ecosystem, is necessary to understand the establishment of invasive species (Hobbs \& Humphries, 1995; Lonsdale, 1999; With, 2002). The development of general rules may aid ecologists in preventing invasive plant species spread, minimise the damage to an infected ecosystem and aid in restoration goals (Newsome \& Noble, 1986; Hobbs \& Humphries, 1995; Allendorf \& Lundquist, 2003). However, many of the hypotheses presented in the literature are not supported by experimental evidence. Regardless of the approach taken to further the understanding of invasiveness, scientific experimentation for the purpose of validation is necessary (Burke \& Grime, 1996).

\subsection{Soil Seed Bank Studies}

A soil seed bank is the totality of viable seeds present within the soil and litter layer. Most of the seeds in the soil seed bank come from the plant communities in the above ground vegetation that is locally present within an ecosystem (Leck et al., 1989; Begon et al., 1990; Bekker, 1998). Long range dispersal of plant species, usually spread by wind, 
water, or animals, is less common but can make substantial contributions to the soil seed bank (Leck et al., 1989; Warr et al., 1993). Some species do not propagate through seeds; rather, they reproduce through vegetative propagation. These species create a bud bank that consists of bulbs, bulbils, buds on rhizomes, corms and tubers. A bud bank is similar to a seed bank insofar as the species are able to disperse through time and space in addition to requiring specific germination cues such as fire or drought (Leck et al., 1989). However, as opposed to seeds, a bud bank does not introduce any genetic novelty.

The study of soil seed banks originated under the banner of population biology, which is concerned with how natural selection works and how species adapt over time in a geographical area (Harper, 1977; Solbrig et al., 1979; Silvertown, 1982). Historically, the study of soil seed banks was closely related to weed studies by agronomists in order to understand the contribution of seeds in the establishment of weeds in agricultural systems. Seed population models were built to determine the emergence rate of different species from the soil seed bank for the purpose of crop management, which incorporated weed control programs and the ability to determine how many seeds needed to be sown to obtain an economically viable crop (Roberts, 1981). This later expanded to include the density at which seeds should be sown, the causes of mortality, and the effects of competitors, predators and disease (Silvertown, 1982).

Academically, soil seed banks were studied spatially for the purpose of understanding how plant populations functioned. Darwin's theory of evolution was adopted by plant ecologists which led them to believe that soil seed banks could provide evolutionary 
information, such as selective environmental conditions of the past, because seeds are thought to conserve genetic variability that aids in their adaptation to survive (Leck et al., 1989). Recently, temporal dynamics have been included in the study of soil seed banks. An important element of temporal dynamics is the classification of seeds as transient or persistent. Transient seeds germinate within one year of their dispersal from the parent plant, while persistent seeds can remain viable, but dormant, in the soil for more than one year (Silvertown, 1982).

Not all seeds become a part of the soil seed bank because many are lost to predators, pathogens, chemical deterioration and the species' inherent seed longevity. Due to these losses and a variety of abiotic and biotic factors that permit or prohibit germination, the above ground vegetation will not necessarily reflect that of the soil seed bank (Leck et al., 1989; Begon et al., 1990, Kirkham \& Kent, 1997). What remains viable in the soil seed bank is vital to the ecosystem processes of renewal insofar as the seeds present may determine future plant communities if appropriate germination requirements are met. Dormant seeds form the largest part of a seed bank and generally come from annuals or ephemerals because these species have short life spans and tend to reproduce an abundance of small seeds (Begon et al., 1990; Bekker et al., 1998). Longer living plant species have more opportunities for reproduction over time and are less likely to produce large persistent seed banks (Baskin \& Baskin, 1998). Differences between the above ground vegetation and viable seeds in the soil seed bank are also attributed to the inherent persistence of a particular species and current management of the vegetation, if it differs from past practices (Bekker et al,, 1997; Kirkham \& Kent, 1997; Akinola et al., 1998). 
Seed dispersal from neighbouring areas can also contribute seeds that are absent in the above ground vegetation to the soil seed bank although such contributions are generally minor. The majority of seeds produced from vascular plants are deposited near the base of the plant or, if aided by flight appendages, within one meter of the plant (Silvertown, 1982).

The practical importance of soil seed banks studies is to manage the vegetation above ground. Ecologists believe that if they adequately understand what is in the soil seed bank, such as viable seeds of persistent species and the quantitative numbers of these species, they may be able to manipulate the ecosystem to promote the germination of the desired species (Harper, 1977; Begon et al., 1990). The practice of manipulating ecosystems to promote the growth of desired species has been used for centuries by foresters, conservationists, agriculturists and gardeners. For example, if a conservationist wanted to restore a prairie and knew that the ecosystem was fire-dependent, performing a controlled burn would likely promote the germination of the desired species if the ecosystem had a persistent seed bank. Similarly, foresters know that by creating openings in the canopy, the bud bank and seed bank will begin to grow.

Some plant ecologists believe that if soil seed banks were thoroughly understood predictions could be made about which species would dominate after a specific disturbance. Although research is still in its infancy, the study of the soil seed bank in conjunction with natural or created disturbances, such as fire or a change in current management practices, has been conducted in a few ecosystem types (Leck et al., 1989; 
Akinola et al., 1998). Researchers are still not able to predict the community structure that will develop above ground but progress is being made in this field. In order to promote native plant communities, researchers know that the soil seed bank must contain viable seeds of the native species and few of the unwanted seeds. This is unlikely to occur in ecosystems that contain multiple invaders that have been present in the ecosystem for some time. Furthermore, the biotic and abiotic conditions must also favour the preferred species for success (Leck et al., 1989).

There are several elements that can influence the soil seed bank, such as climate, seed mortality rates, seed longevity, allelopathy, seed persistence, seed dormancy, and abiotic and biotic factors that vary depending on the ecosystem type. Moreover, studies that exist are often difficult to compare or assimilate because of a lack of standardised techniques (Leck et al., 1989). Another problem is that most of the experiments reported have been conducted in laboratory settings with direct control over important aspects of ecosystem functions such as climate, moisture and light. Laboratory studies are referred to as the safe site (Silvertown, 1982). Safe sites are not sufficient to predict germination in the field because seeds are highly responsive to micro differences in the abiotic environment at the soil surface level. Furthermore, safe sites allow many of the seeds to escape the risks associated with the pre-germination phase, such as predation or exposure to various pathogens. In nature, many of these seeds would die (Harper, 1977; Silvertown, 1982). As the complexities of selective pressures on seeds in the soil seed bank and the role that specific species play within a community are better understood, general patterns that are ecosystem specific may emerge to form the foundation of a soil seed bank general theory. 


\title{
2.4 Alvar Ecosystems
}

"Alvars are natural communities centered around areas of glaciated horizontal limestone or dolomite bedrock pavement with a discontinuous thin soil mantle. These communities are characterized by distinctive flora and fauna with less than $60 \%$ tree cover, that is maintained by associated geological, hydrologic and other landscape processes."

International Alvar Conservation Initiative, 1995.

\begin{abstract}
Alvars are natural open areas characterized by bare limestone or dolomite interspersed with thin soils. Vegetation primarily consists of shrubs and herbaceous plants. There is a distinct lack of trees since they can not be supported by the thin soils nor survive the dry conditions that exist during the growing season. What makes the vegetation of these rare ecosystems so diverse is the presence of northern, western and southern plant species coexisting. Alvar plant communities are believed to have originated in tundra-like habitat during the last period of glaciation and have since maintained their resemblance to that era due to unique microclimates influenced by unusual geological and hydrological processes (Brunton, 1988; Catling \& Brownell, 1995; Bouchard \& Wheeler, 1997; Schaefer \& Larson, 1997).
\end{abstract}

\begin{abstract}
Alvars exist only in two regions of the world - the Baltic Sea Region and the Great Lakes Basin of Canada and the United States. There are approximately 300 known alvar sites in North America. The majority of sites are located in southern Ontario in the area that extends from the Smiths Falls Limestone Plain in the east to Lake Huron in the west, and north to the contact line of the granitic Canadian Shield (Belcher et al., 1992; Bouchard \&
\end{abstract}


Wheeler, 1997; Brownell \& Riley, 2000). Ontario has six alvar regions: Manitoulin Island, the Bruce Peninsula, Carden Plains, Smiths Falls Plains, Napanee Plains and Pelee Island. Within these six regions, six types of communities have been identified [Table 2].

Table 2: Alvar community type classifications

\begin{tabular}{|l|c|c|}
\hline & Open Alvar: $<10 \%$ tree cover & $\begin{array}{l}\text { Savannah: } 10-15 \% \text { tree } \\
\text { cover }\end{array}$ \\
\hline $\begin{array}{l}>50 \% \text { exposed bedrock } \\
<50 \% \text { herbs } \\
<50 \% \text { shrubs }\end{array}$ & Pavement Alvar & Pavement Savannah \\
\hline $\begin{array}{l}<50 \% \text { exposed bedrock } \\
>50 \% \text { herbs } \\
<25 \% \text { shrubs }\end{array}$ & Grassland Alvar & Grassland Savannah \\
\hline $\begin{array}{l}<50 \% \text { exposed bedrock } \\
<50 \% \text { herbs } \\
>25 \% \text { shrubs }\end{array}$ & Shrubland Alvar & Shrubland Savannah \\
\hline
\end{tabular}

Source: Bouchard \& Wheeler, 1997.

The Nature Conservancy of Canada has classified pavement alvars and grassland alvars as globally imperilled. Aside from the unique composition of species found in these areas, alvars contain many plants and insects that are either threatened or endangered (White, 1979; Catling \& Brownell, 1995; Bouchard \& Wheeler, 1997; Brownell \& Riley, 2000). A small number of endemic plants, such as the Lakeside Daisy (Hymenoxys herbacea), Dwarf Lake Iris (Iris lacustris) and Pitcher's Thistle (Cirsium pitcheri), are now restricted to the alvars in Ontario (Bouchard \& Wheeler, 1997; Brownell \& Riley, 2000). 
Until recently, many of the known alvar sites within the Great Lakes Basin were

considered in relatively pristine condition. However, urban development, quarrying, timber operations and site selection for landfills are threatening these unique ecosystems (Brownell \& Riley, 2000). Aside from containing a high concentration of rare or endangered species, alvars are important for future biological research in the fields of natural history, plant physiology and for the preservation of biodiversity (Bouchard \& Wheeler, 1997; Brownell \& Riley, 2000). For these reasons, the Ontario Federation of Naturalists, the Nature Conservatory of Canada and various government departments, especially the Ontario Ministry of Natural Resources (OMNR), are emphasising research on alvars in an effort to assist in making sound conservation decisions (Bouchard \& Wheeler, 1997).

\subsection{The Burnt Lands Nature Reserve}

The Burnt Lands, listed as an Area of Natural and Scientific Interest (ANSI) and rated as having outstanding significance (Class B1) by the International Alvar Conservation Initiative, is one of North America's best examples of an alvar due to its size and the presence of globally rare plant communities. Located approximately five kilometres northeast of Almonte, Ontario [Figure 1], the Burnt Lands is jointly owned by the Crown and the Nature Conservancy of Canada (NCC) [Figure 2].

The Burnt Lands is 2338 ha in size and contains a mosaic of ecosystem types including alvar, mixed and coniferous forests and portions of three elevated wetlands (White, 1979; Brownell \& Riley, 2000). One hundred and thirty-five hectares are classified as a nature 
reserve by the Ontario Ministry of Natural Resources, due to the presence of Annual Alvar Pavement Grasslands and Poverty Grass Dry Alvar Grasslands, both of which are considered the best examples of these communities in the world (Bouchard \& Wheeler, 1997; OMNR, 2000).

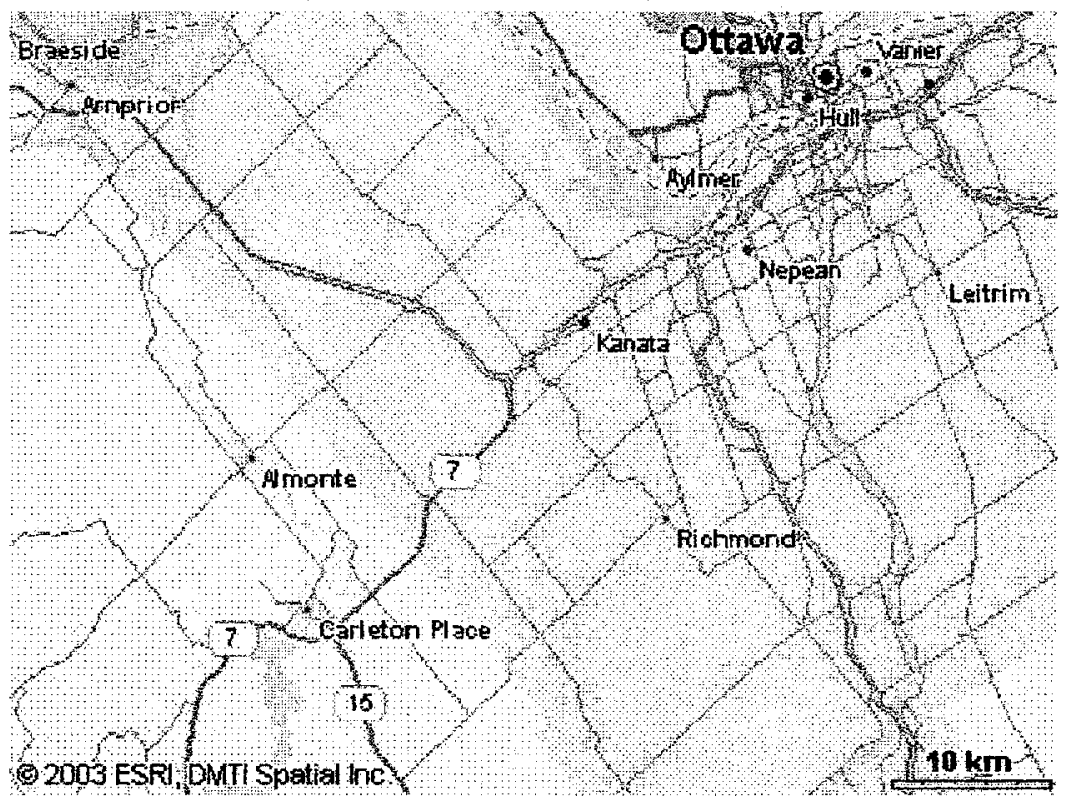

Figure 1: Map showing Almonte in relation to Ottawa, Ontario. Source: ESRI, 2005.

The Burnt Lands gained its name following a severe wildfire that swept through the area in 1870 . In the 1940 s and 1950 s, this area was logged and subsequently used for grazing until the 1960s (Brownell \& Riley, 2000). In the era of the Cold War, a 135 ha area was purchased by the Department of National Defence (DND) for the construction of communication towers. In the 1950 s an atomic bomb shelter (known as the 'Diefenbunker') was built in Carp, Ontario and the communication site at the Burnt Lands was meant to act as a fail-safe communication system in the event that the systems in Carp were bombed or failed. This area is now known as the 'former DND property' and 


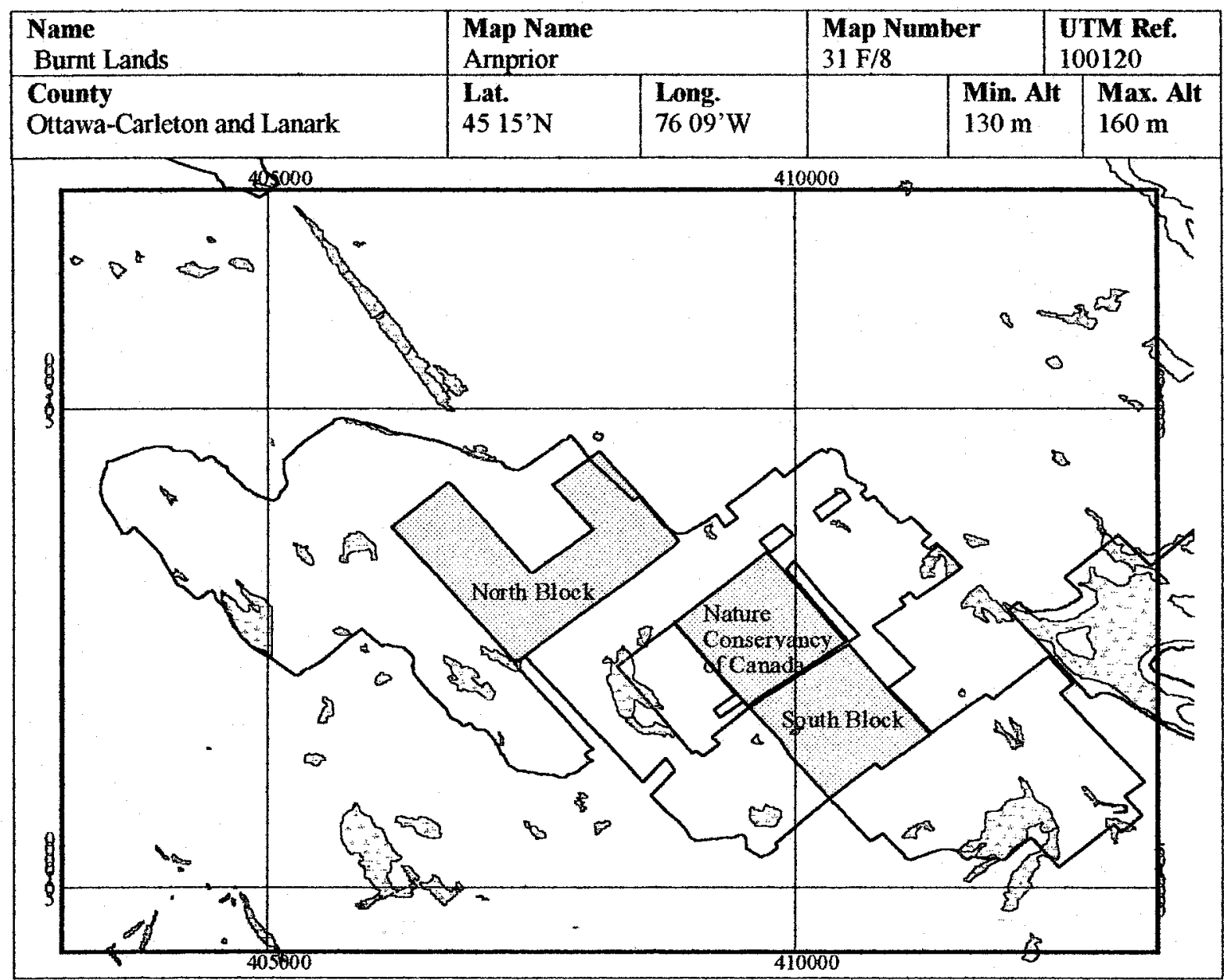

Figure 2: Map of Burnt Lands Nature Reserve. The North Block, NCC block and the South Block are publicly owned. The vast majority of the Burnt Lands is privately owned as shown in this map which outlines the entire Burnt Lands Alvar Source: OMNR, 2000.

has recently been donated to the Nature Conservancy of Canada (Cuddy, personal communication, 2004). The former Regional Municipality of Ottawa-Carleton designated 750 ha of the Burnt Lands as conservation land in 1974. However, in the 1990s this status was changed to 'managed resource restricted' allowing the construction of several private residential homes (Brownell \& Riley, 2000). The most recent major disturbance at the Burnt Lands was another wildfire in 1999. This fire occurred in heavily wooded areas on Crown land and was contained to approximately 150 ha (Catling 
et al., 2001; Catling \& Sinclair, 2002). Today, the majority of the Burnt Lands is

privately owned. The public areas of the Burnt Lands are used for a variety of recreational purposes including horseback riding, hiking, hunting and the use of all terrain vehicles (personal observations).

The Burnt Lands Nature Reserve has been studied intensively since the 1970s. Once described in the literature as rock flats or old fields, the term alvar was first applied by Beschel who was familiar with alvar ecosystems in Sweden, Denmark and Estonia (Brownell \& Riley, 2000). Alvar ecosystems are of general interest to researchers for the diversity and number of rare species they support (White, 1979; Brunton, 1988). These rare species have generated interest taxonomically, which is the primary reason that the Burnt Lands have been studied. In 1986, Daniel Brunton created a life science inventory of the Burnt Lands for the OMNR. This life science inventory, a comprehensive list of the vascular plants present on the public portions of the Burnt Lands Nature Reserve held by the OMNR, has been updated over the past 18 years by V. Brownell, P. Catling, D.Cuddy and various staff at the OMNR.

The Burnt Lands is listed as Class B (good condition) by the Federation of Ontario Naturalists (Brownell \& Riley, 2000). Eight species found in the Burnt Lands Nature Reserve are listed as provincially important and 16 species are classified as locally significant because they are rare or extirpated from much of the region (OMNR, 2000) [Table 3]. 
Since most of the Burnt Lands is privately owned, there are risks of future development and management practices that could destroy this unique ecosystem. Furthermore, invasive plant species, such as Buckthorn (Rhammus spp.), Barberry (Berberis vulgaris), Purple loosestrife (Lythrum salicaria) and Cypress Spurge (Euphorbia Cyparissias), that are not serious threats to this site at present, may become serious competitors in the future if they are not managed.

Table 3: List of significant plants present on the Burnt Lands Nature Reserve

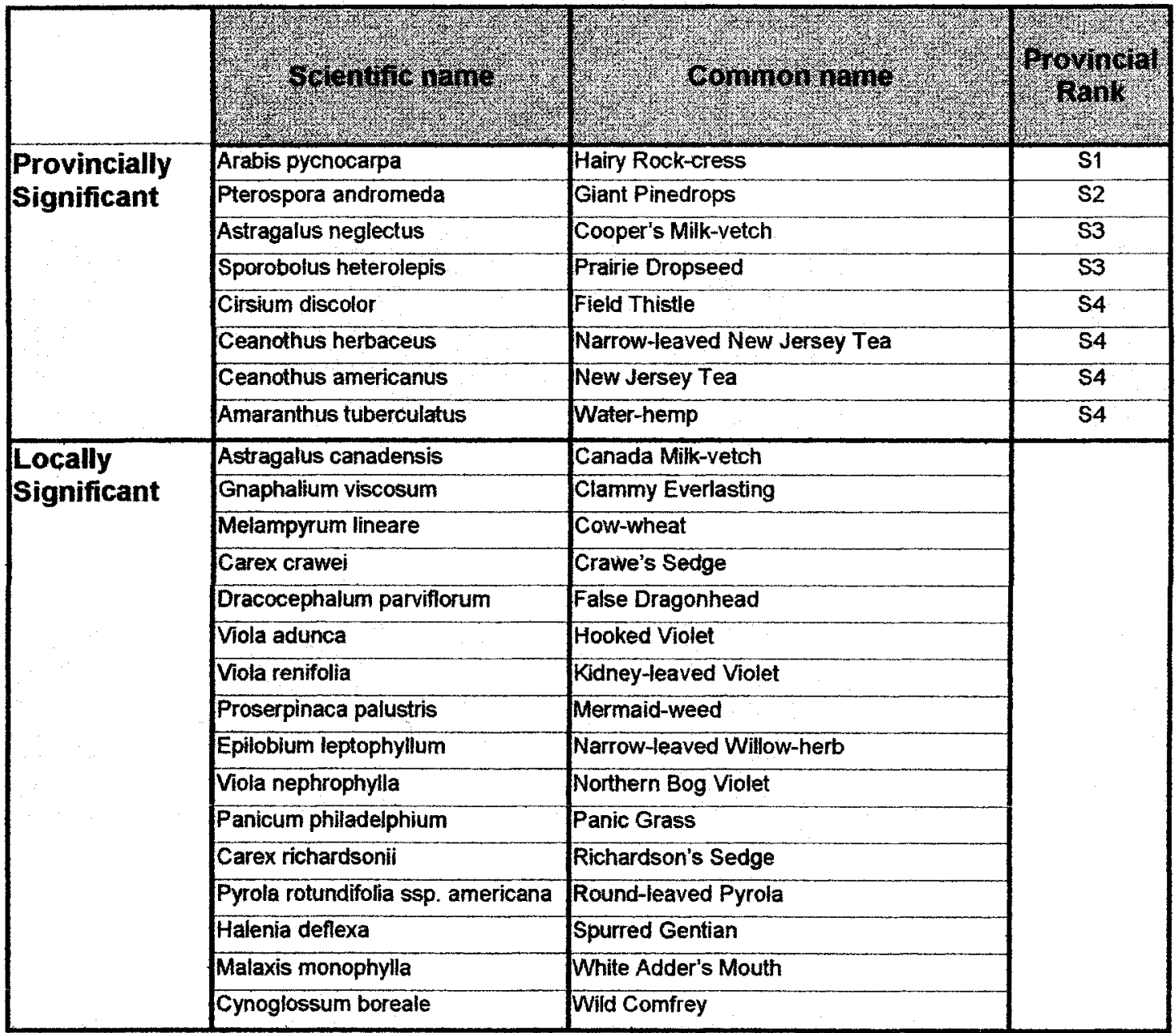

S1: extremely rare in Ontario $\$ 2$ : very rare in Ontario \$3: rare to uncommon in Ontario S4: common in Ontario The Ontario Natural Heritage Information Centre, for the purpose of establishing protection priorities for rare species and natural communities, provides rank classifications: These ranks are not legal.

Locally significant plants are considered rare to a region but these species are not ranked or monitored by the Ontario Natural Heritage Information Centre (OMNR, 2000).

Source: Brownell \& Riley, 2000; OMNR, 2000 


\subsection{Alvar Soil Seed Bank Studies}

Two alvar soil seed bank studies have been reported. The first study was conducted in dry alvar grassland on the Baltic Island of Oland in Sweden (Bakker et al., 1996). Its purpose was to determine if the soil seed bank could play a vital role in the restoration of this ecosystem. This dry alvar grassland had been grazed for many centuries. In areas where grazing has ceased, common juniper has taken over and replaced the native diversity of grassland alvar species. Researchers attempted to discover if the native species would re-establish from the soil seed bank if the juniper were removed. They found that the seeds in the alvar were transient and, therefore, unable to aid in restoration goals.

The second study was conducted on five alvar sites located in the Bruce Peninsula National Park in Ontario, Canada (Stark et al., 2003). It is the first soil seed bank study on a North American alvar ecosystem. Stark et al. (2003) had two main objectives:

1. To determine if the surrounding forest was encroaching on the alvar sites by assessing vegetation cover and soil seed banks for both open alvar sites and forest margins; and,

2. To determine relations between vegetation cover, soil seed bank species and soil characteristics.

They found that the surrounding forest was not encroaching on open alvar habitat even when there was adequate soil and nutrients to support tree species. They found a lack of woody forest species in alvar plots as well as a lack of alvar grassland species in the forest margins. Furthermore, they did not detect significant relations between vegetation 
cover, seed bank species and soil characteristics, although there was a weak relation between plots with high vegetation cover and a greater soil depth (Stark et al., 2003).

\subsection{Euphorbia cyparissias as a Target Species}

Euphorbia cyparissias is a semi-woody perennial plant that is a member of the Euphorbiaceae family. This species originated in Eurasia and is considered native throughout Europe, from southern Finland to northern Greece and from England in the west to central Siberia in the east (Stahevitch et al., 1988; Van Driesche, 2002).

Euphorbia cyparissias, commonly known as graveyard weed, was introduced to North America in the 1860 s as an ornamental plant that was widely cultivated in graveyards [Figure 3]. Since its introduction to North America, Euphorbia cyparissias has escaped its intended cultivated areas and colonised other ecosystems. In Canada, this species is most prevalent in the east from Nova Scotia to Ontario. Although there are accounts of this species as far west as the eastern border of Alberta, there are only 19 sites reported to contain Euphorbia cyparissias west of Lake Huron (Stahevitch et al., 1988).

There are three cytogenetic variants of Euphorbia cyparissias, which include a fertile diploid, a sterile diploid and a fertile tetraploid. Only the sterile diploid and fertile tetraploid are found in Ontario (Stahevitch et al., 1988; Van Driesche, 2002). The sterile diploid is the most common and reproduces solely through underground parts, namely through rhizomes or parts of the root stock (Ontario Ministry of Agriculture and Food, 2003). The fertile tetraploid reproduces through both underground parts and fertile seeds. The fertile tetraploid has been reported in both Dufferin County and eastern Renfrew 
County where it occupies thousands of hectares of pasture lands and other open habitats such as roadsides (Stahevitch et al., 1988; Ontario Ministry of Agriculture and Food, 2003). The cytogenetic variant present at the Burnt Lands Nature Reserve is not currently known.

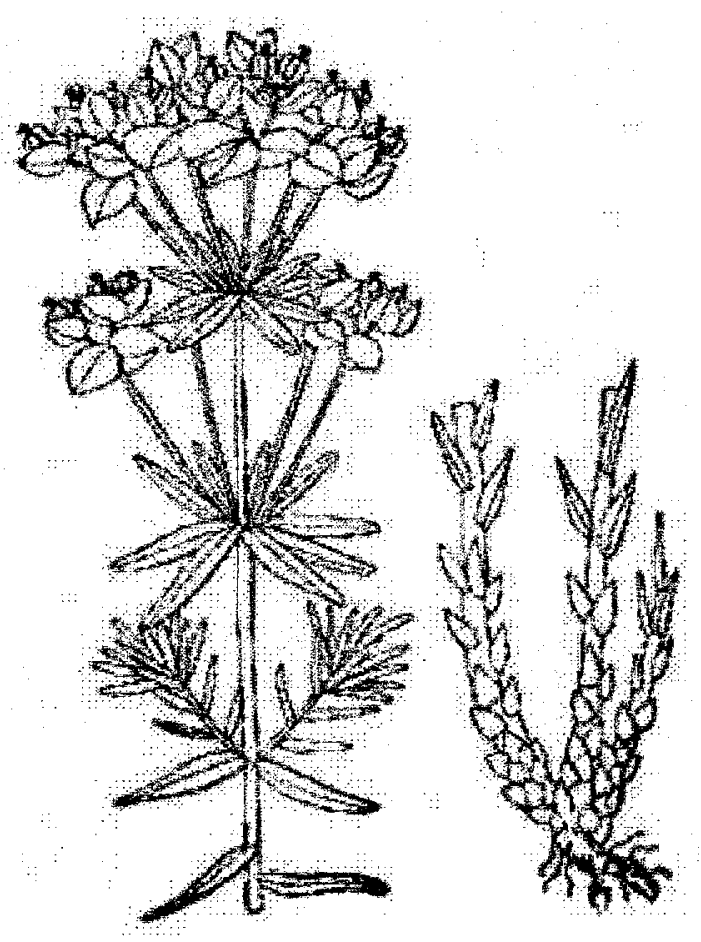

Figure 3: Artist sketch of Euphorbia cyparissias. Source: Plant National Database (U.S.A.), 2005.

Euphorbia cyparissias is typically found in open habitats, such as roadsides, pasture lands or abandoned fields but rarely appears on heavily cultivated soils. This species prefers sandy, sandy loam or gravel-based soils that are fairly dry. Although its tolerance range extends from drought-like impoverished conditions to moderately wet sites, this species has also adapted to a wide range of climatic conditions, from the warm temperate climates of Tennessee to cooler, snow climates in the Gaspé Peninsula of Quebec. In 
Ontario, Euphorbia cyparissias favours dry sandy soils on limestone substrate (Stahevitch et al., 1988; Ontario Ministry of Agriculture and Food, 2003).

Euphorbia cyparissias has an extensive root system that consists of a persistent and indeterminate taproot and lateral roots. Young seedlings produce the taproot that reaches a length of 3 metres or more. Lateral roots form off the taproot and produce several adventitious buds. In early spring, shoots form from the crown and buds develop in masses (Van Driesche, 2002). Due to this extensive root system, control of Euphorbia cyparissias is difficult to achieve. Normal applications of pesticide appear to have little effect on this species. Research suggests that pesticide must be applied frequently in order to control the spread of Euphorbia cyparissias; these applications do not eradicate the species (Stahevitch et al., 1988; Ontario Ministry of Agriculture and Food, 2003). Biological control has been attempted in Canada but has not been fully successful. Three root-boring moths that feed on Euphorbia spp. were introduced in Belleville and Sidney, Ontario, but failed to establish. Chrysomelidae, a root-feeding beetle, was subsequently introduced into these ecosystems and showed some promise as a biological control (Stahevitch et al., 1988). Follow-up of this experiment is not publicly documented.

For many years, the appearance of cypress spurge was not noteworthy. The public found this species to be an attractive ground cover along roadsides and other open urban places. However, Euphorbia cyparissias has escaped its intended bounds and invaded other ecosystems, such as pastures, dry grasslands and alvars. All parts of Euphorbia cyparissias contain a milky latex that is toxic to cattle and other range animals. Cases of 
cattle dying after the ingestion of Euphorbia cyparissias have been reported in the United States. Humans also suffer adverse effects from being in contact with this milky latex, including dermatitis and severe irritation of the skin, mouth and gastrointestinal tract (Stahevitch et al., 1988; Van Driesche, 2002; Ontario Ministry of Agriculture and Food, 2003). Furthermore, this species has the ability to choke out native vegetation by forming pure stands, thereby drastically reducing biodiversity in natural ecosystems (Stahevitch et al., 1988; Van Driesche, 2002; Ontario Ministry of Agriculture and Food, 2003; OVMA, 2003). Euphorbia cyparissias also has the potential to become a serious competitor in natural ecosystems. For example, in 1975, the United States reported the presence of Euphorbia cyparissias in 26 states. By the year 2000, Euphorbia cyparissias was present in 42 states (Van Driesche, 2002). Today, Euphorbia cyparissias has fallen into disfavour as an ornamental due to its toxicity to livestock and invasive potential. This species is now listed as a noxious weed in most provinces and states (Stahevitch $e t$ $a l ., 1988)$. 


\section{METHODOLOGY}

Combinations of fieldwork and laboratory methods were used in this study. The fieldwork consisted of: A visual reconnaissance of the Burnt Lands for the purpose of selecting an appropriate site for the soil seed bank study; selection of sixty plots placed along six transects at ten plots per transect; measurement of the crown closure of cypress spurge and soil depth in each plot; collection of soil samples for the soil seed bank study and soil analysis; and a vegetation survey in each of the 60 plots to compare with the soil seed bank. Laboratory research consisted of a soil seed bank study conducted in a greenhouse at the National Wildlife Research Centre located on campus at Carleton University, Ottawa. Each of these methods is outlined in detail in the following sections.

\subsection{Visual Reconnaissance and Site Selection}

During the summer of 2003, field visits to Burnt Lands Nature Reserve were made on June $26^{\text {th }}$, July $1^{\text {st }}$, and August $9^{\text {th }} 2003$ for the purpose of site selection based upon visual reconnaissance. The Nature Conservancy of Canada (NCC) property (formerly occupied by the Department of National Defence) was selected as the primary focus for this study. This 135-hectare section of the Burnt Lands Alvar contains two vegetation communities considered to have significance: Grassland Alvar and Pavement Alvar [Table 2 in Section 2.3]. This area has experienced extensive damage from use by both the former occupants (DND) and the general public. Specific damage includes the removal of shrubs and trees, the installation of permanent structures (DND bunker), road maintenance, horseback riding, illegal garbage dumping and the use of all-terrain vehicles. Despite these 
disturbances, this property continues to support important alvar plant communities that are both rare and endangered.

A gravel roadway accessed from Regional Road 49 runs north - northeast through this property. Euphorbia cyparissias is present along both sides of the gravel roadway, with significant communities extending approximately 25 meters east and west of the road, extending north of a barbed wire fence and south of the DND bunker. This area was selected as the research site because it is the only area on this property where Euphorbia cyparissias was present [Figure 4].

\subsection{Site Layout}

There is no single acceptable methodology for conducting soil seed bank studies or vegetation surveys; therefore, the methods employed must be designed in accordance with the research objectives (Jones, 2000; Barker, 2001). Because the Daubenmire Scale is a proven and accepted tool for estimating ground level canopy cover, species frequency, species composition, vegetation conditions and trends (Jones, 2000; US Fish and Wildlife Service, 2003), it was selected as an appropriate protocol for the vegetation survey and the assessment of canopy cover for the target species in this study. 


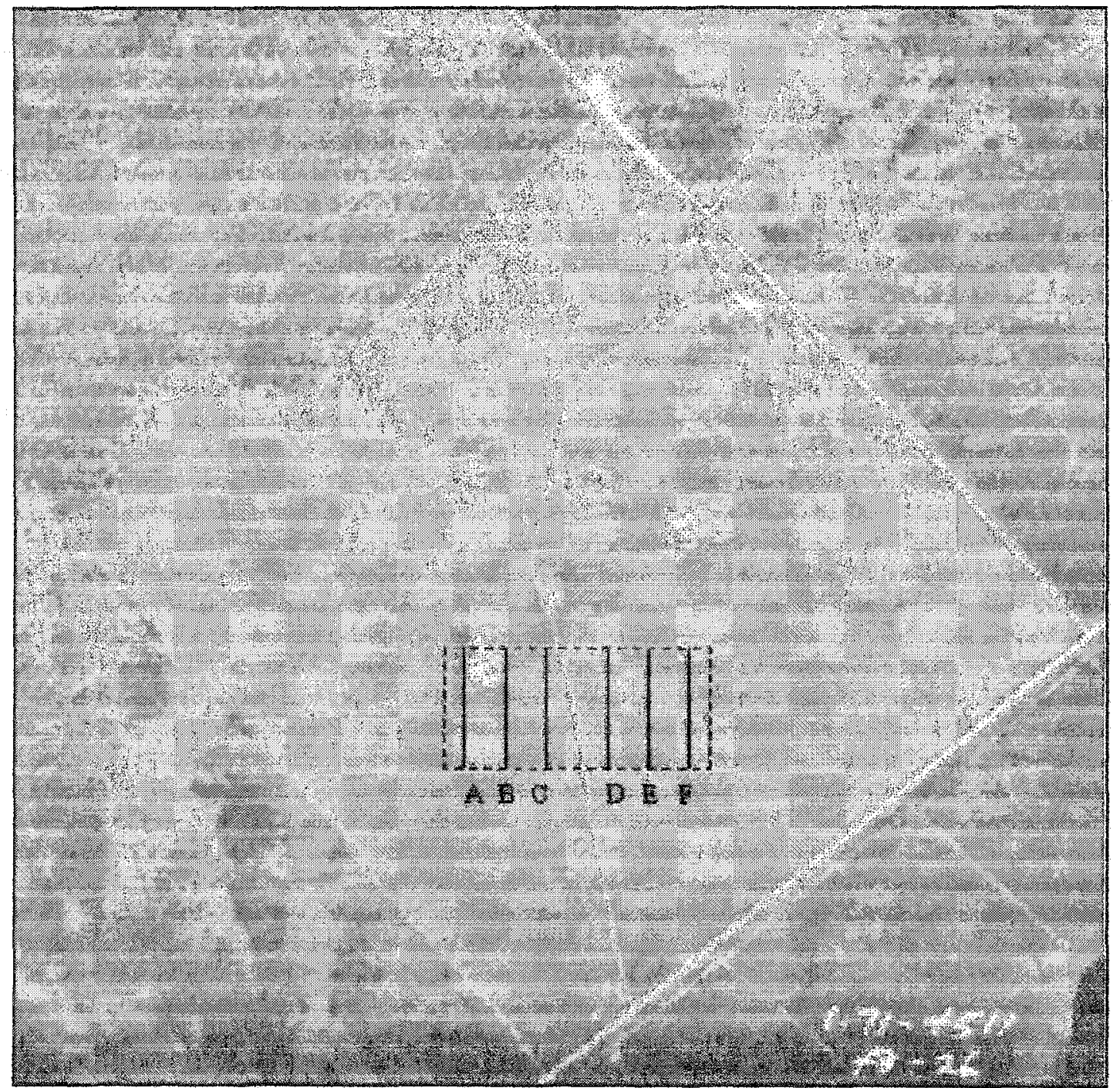

Figure 4: Aerial photograph of the Burnt Lands Nature Reserve showing the selected research site. Dashed box indicates research area; solid lines indicate transect locations (not to scale).

Six transects 100 meters in length, 10 meters apart and orientated at 25 degrees magnetic north were established in the field. Three transects were located along each side of the gravel road. The central point of commencement (POC) was the junction of the first fence post on the western side of the road and the edge of the gravel road. Each transect commenced 10 meters north of the fence line, with the first transect on each side being 10 
meters from the edge of the gravel road. The transects crossed areas where Euphorbia cyparissias has invaded and extended into areas where this species is not yet present. Temporary markers were placed in the field to indicate the POC and the transect lines. Permanent markers were not permitted within the site and the temporary markers have since been removed as requested by the OMNR at the time that approval was granted to conduct this research.

\subsection{Sampling}

On September 17, 2003, ten quadrats (quadrat size $20 \mathrm{~cm} \times 50 \mathrm{~cm}$ ) were placed along each transect at random meter locations that were determined prior to the commencement of the fieldwork through the use of a random number table (Berenson et al., 1988). The quadrat frames were positioned with the lower left corner located at the meter point to the east of the transect line. In the event that one of the predetermined quadrats landed on alvar pavement (where no soil was present), the quadrat was moved to the first available meter point further along the transect that contained soil.

Canopy cover of the target species (Euphorbia cyparissias) was assessed using per cent cover. The cover of Euphorbia cyparissias was determined by visual observation and included individual plant canopies that extended into the quadrat regardless of whether the plant was physically rooted within the quadrat. For the purpose of statistical analysis where Euphorbia cyparissias was used as the independent variable, per cent cover was used to ascertain differences between levels of this species in each plot. The majority of Euphorbia cyparissias had bloomed in late June and early July of 2003 and was 
beginning to die. This resulted in a net decrease in per cent cover at the time of this survey. For this reason, crown closure was re-assessed in early July of 2004 during the peak bloom season. The per cent crown closure for 2004 was used for statistical analysis.

Scientists recommend that soils for soil seed banks studies should be collected in early spring before species flower and set seeds. However, it is also acceptable to collect samples in the late fall after the final seed rain if the soils receive subsequent treatment such as cold stratification to mimic natural conditions (Leck et al., 1989). Two soil cores were obtained from each quadrat using a bulb planter. Soil cores were $6.5 \mathrm{~cm}$ in diameter and $10 \mathrm{~cm}$ deep. If the soil did not reach a depth of $10 \mathrm{~cm}$, three or four soil cores were collected within the quadrat to account for the one litre of soil required from each plot. These samples were bagged and labelled for the soil seed bank study and soil analysis. The vegetation and the litter layer were not removed from cores at the time of collection because they may have contained seeds valuable for this study. The soil cores collected within each plot were bulked to form one composite sample per plot. Soil depth within each plot was measured in centimetres where one of the cores was extracted.

\subsection{Soil Seedbank Study}

The soil samples collected on September 17, 2003, were taken to Environment Canada's National Wildlife Research Centre (NWRC) located at Carleton University where they were refrigerated for a period of three weeks. On October 8,2003 , the soil samples were removed from the refrigerator where they had been stored between 0 and 4 degrees Celsius to mimic winter conditions under snow cover. Soil samples were cleaned of 
debris and rock by hand. Five hundred millilitres of the soil material were removed from each plot and spread evenly into individually labelled plastic trays that contained drainage holes. Each tray was lined with a fine weave cotton cloth to prevent seed loss during the experiment. Trays were placed in the greenhouse at NWRC where they were watered daily. Greenhouse conditions were monitored and the temperatures ranged between 17.2 degrees Celsius and 30.8 degrees Celsius. Lights were turned on daily between the hours of $6 \mathrm{AM}$ to $9 \mathrm{AM}$ and again from $5 \mathrm{PM}$ to $10 \mathrm{PM}$ from October, 2003 through March, 2004. The extended hours of light exposure simulated summer conditions in the field. Three control trays containing sterile soil were placed among the samples to detect any cross contamination of seeds between trays.

By November 7, 2003, the germination process began but the seedlings were not growing and at risk of dying due to a lack of nutrients in the soil. Most of the seedlings were less than $0.5 \mathrm{~cm}$ tall and changing colour from green to a reddish brown or yellow. To avoid the premature death of these seedlings before the species could be identified, the soils were fertilised using an all-purpose fertiliser. This fertiliser contained $20 \%$ nitrogen, $20 \%$ available phosphoric acid, $20 \%$ soluble potash, actual boron $0.02 \%$, actual chelated copper $0.05 \%$, actual chelated iron $0.1 \%$, actual chelated manganese $0.05 \%$, actual molybdenum $0.0005 \%$, actual chelated zinc $0.05 \%$, and EDTA chelating agent 1.0. Five litres of water with $3.5 \mathrm{~g}$ of fertiliser per litre were evenly distributed across all samples on November 7, 3003. Additional applications of fertiliser were applied on November 21, 2003, January 9, January 23 and February 8, 2004. 
Within each of the 60 samples, plant species were identified, counted and recorded as they germinated. Once the species were identified and recorded, they were removed from the planters thereby allowing space and nutrients for remaining viable seeds to germinate. Species not positively identified were removed from the trays and transplanted into individual pots until their identification could be determined. Once germination appeared to have ceased, the soils were stirred in order to bring remaining seeds to the surface layer where they could germinate. Soils were stirred on December 27, 2003, and on February 8,2004 . The majority of viable seeds will germinate within the first two months (Warr et al., 1993) following planting; samples were monitored daily for this period. However, seedlings continued to germinate in excess of this two-month period, allowing an extension of the experiment until March 27, 2004 when the soil seed bank study was terminated.

\subsection{Vegetation Survey}

On July 5, 2004, a vegetation survey was conducted in the field at the Burnt Lands. The 6 transect lines were re-established in the field using the original post markers. The original 60 plots used for the soil seed bank study were surveyed for species content and crown closure of Euphorbia cyparissias was assessed again. Don Cuddy, a botanist and local taxonomist with extensive experience at the Burnt Lands Nature Reserve, assisted with species identification during the field survey. Species lists and crown closure cover classes of cypress spurge were recorded on field records by plot. 


\subsection{Soil Analysis}

Thirty soil samples were sent for soil analysis at Acutest ${ }^{\mathrm{TM}}$, an independent, accredited private laboratory in Ottawa, Ontario. The high cost associated with laboratory testing and the limited resources available precluded soil analysis of all 60 plots. Thirty samples were selected based upon the presence and absence of Euphorbia cyparissias determined during the initial field investigation of crown closure in September, 2003. Eighteen of the soil samples had cypress spurge present in the vegetation layer and were selected for analysis along with 12 randomly chosen samples where cypress spurge was not present. These samples were stored in the refrigerator at the NWRC until they were sent for analysis on December 19,2003. The soil samples were analysed for the parameters outlined in Table 4.

\subsection{Statistical Analysis}

Histograms were constructed to assess the frequency distribution of each variable [Appendix A]. Since not all variables follow a normal distribution without the removal of the outliers, a non-parametric test was chosen to assess correlations between variables and the per cent crown closure of Euphorbia cyparissias. Spearman's Rank Correlation is a technique used to test the direction and strength of the relation between two variables using Spearman's $r s$ coefficient. Spearman's Rank Correlation is a distribution free analogue of correlation analysis and is often used on non-parametric data (Conover, 1980; Hoaglin et al., 1983; Sregel \& Castellan, 1988) 
Table 4: Soil analysis - parameters and units

\begin{tabular}{|l|l|}
\hline \multicolumn{1}{|c|}{ Parameter } & \multicolumn{1}{|c|}{ Units } \\
\hline N-N03 & ppm (parts per million) \\
\hline P & ppm \\
\hline K & ppm \\
\hline Mg & ppm \\
\hline pH & \\
\hline Organic Matter & $\%$ \\
\hline Sand & $\%$ \\
\hline Silt & $\%$ \\
\hline Clay & $\%$ \\
\hline
\end{tabular}

The formula used for Spearman's Rank Coefficient is:

$$
r s=1-\frac{6 \Sigma \mathrm{d}^{2}}{\mathrm{n}^{3}-\mathrm{n}}
$$

where $\mathbf{n}$ is the sample size for the paired measurements, and $\mathrm{d}$ is the difference in rank between each pair of measurements.

The coefficient ( $r s$ ) falls between +1 (a perfect positive correlation) and -1 (a perfect negative correlation). A value of 0 indicates that there is no relation (Tukey, 1977; Berenson et al., 1988). Spearman's Rank Correlation was applied using SPSS V. 10, to 
assess the statistical strength and relation with the presence and amount of Euphorbia cyparissias to the remaining measured variables in this study.

Histograms and scatter plots are used in this thesis as visual representations of the data for the purpose of showing distribution and correlation. 


\section{RESULTS \& DISCUSSION}

\subsection{Crown Closure of Euphorbia cyparissias}

Euphorbia cyparissias was in 32 of the 60 plots examined [Appendix B]. The per cent of crown closure ranged between $0 \%$, where no Euphorbia cyparissias was present, to $30 \%$. The mean was $3.9 \%$ distributed across all 60 plots [Figure 5]

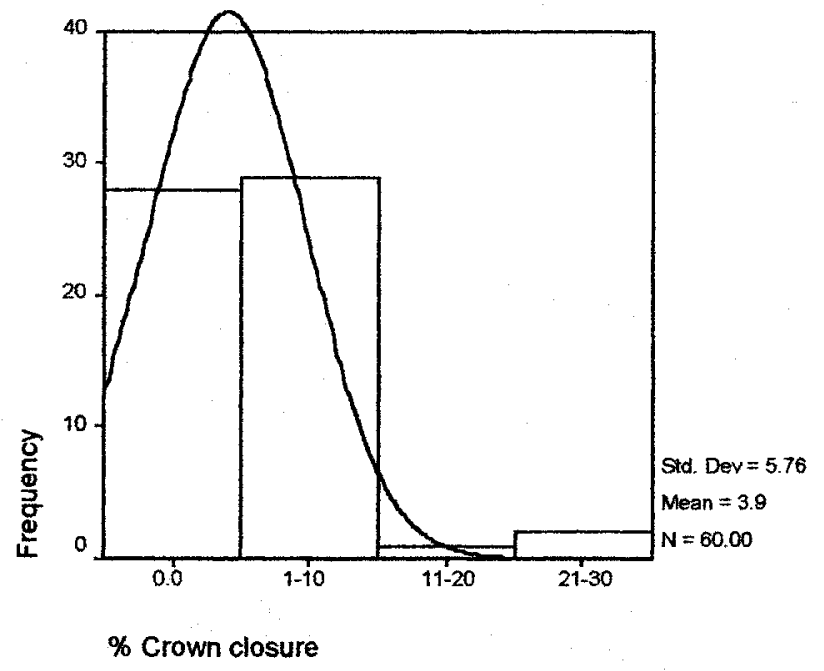

Figure 5: Histogram showing the distribution of Euphorbia cyparissias as \% crown closure in 2004.

Crown closure of Euphorbia cyparissias is treated as the independent variable against which all other components of this study will be evaluated 


\subsection{Species Composition}

Species composition was determined by identifying and counting species that germinated in the soil seed bank study and that rooted within each of the 60 plots for the vegetation survey. A total of 25 species germinated in the soil seed bank study and 51 species were recorded during the vegetation survey. In the vegetation survey, 8 plants were unidentified because they were immature; they are recorded as unknown. In addition to these unknown plants, three plants were identifiable only by family (Agrostis spp., Solidago spp. and Viola spp.). Unknown species that could be duplicates of identified species were not included in the statistical analysis due to the possibility of biasing the results. There was only one plant from the violet family identified in the vegetation survey and this plant was included in the species composition because there was no chance of duplication. A total of 49 species were used in the statistical analysis for the vegetation survey [Table 5].

Species in the soil seed bank were recorded by date and number of individuals as they germinated [Appendix C]. The vegetation survey identified plant species by plot but the number of individual plants of each species in each plot was not determined. Therefore, only the number of species can be cross-compared between the two surveys. Nine species, including Acer spp., that grew in the soil seed bank study did not appear in the above ground vegetation during the field survey and 33 species from the vegetation survey were not found in the soil seed bank study. The first species to germinate, if its seeds were present in the plot, was Hypericum perforatum, followed in order by Verbascum thapsus, Leucanthemum vulgare, Daucus carota, Melilotus alba, and 
Table 5: Species composition in the soil seed bank study and vegetation survey

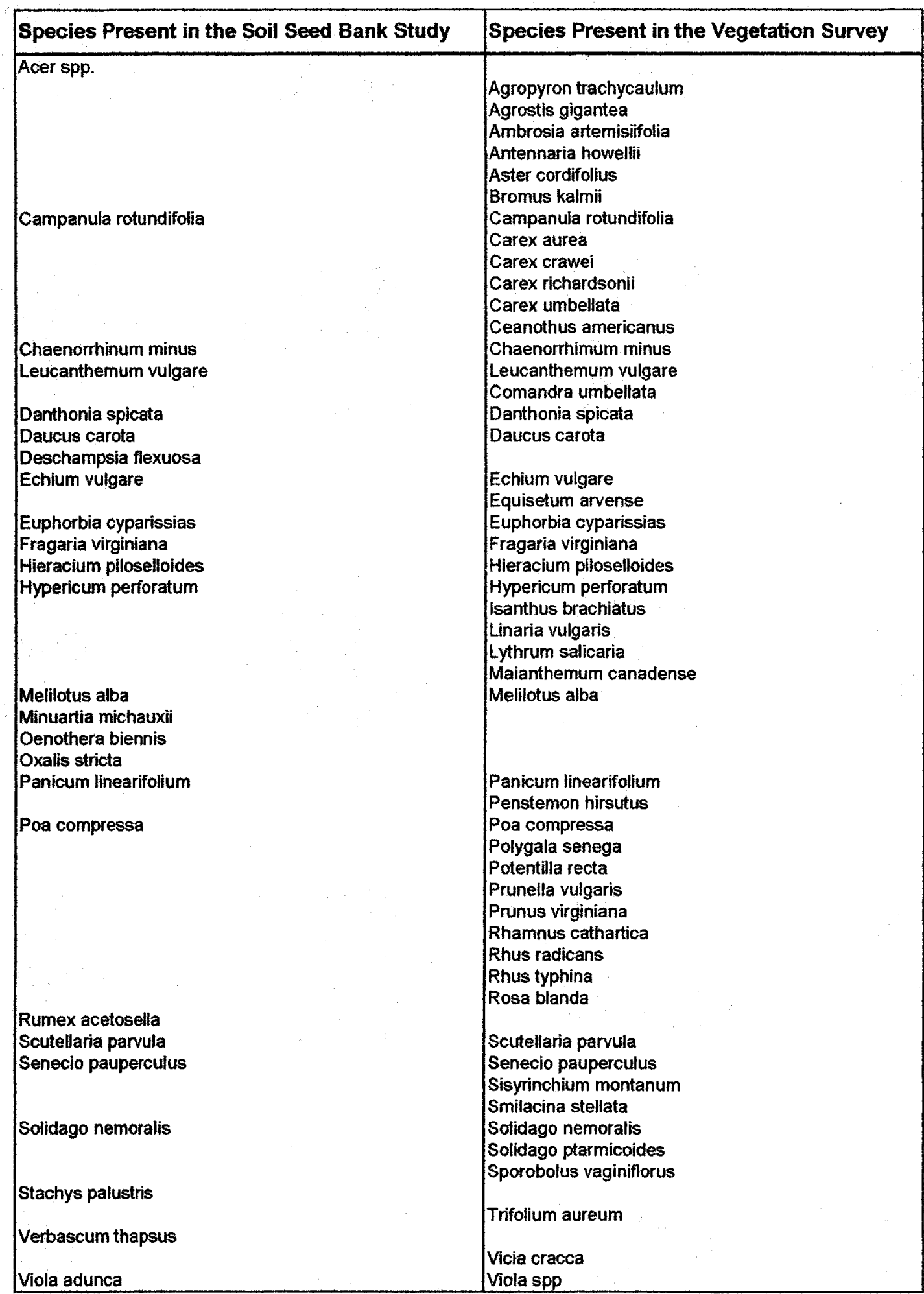


Oxalis stricta. All of these species are considered alien and with the exception of

Leucanthemum vulgare, they are also invasive species (White et al., 1993). This pattern of species appearance occurred each time that the soils in the trays were stirred to promote further germination.

When the results of the soil seed bank study and vegetation survey were combined, there was a total of fifty-seven plant species. The majority of these species were perennials with five annuals and five biennials [Table 6]. A greater percentage of annuals were expected to appear in the soil seed bank because annuals are generally reported to form large persistent soil seed banks (Begon et al., 1990; Bekker, 1998). However, only two annuals were identified in the soil seed bank study while the remaining three appeared in the vegetation survey. Twenty of the total species were alien, and thirty-seven were native. Thirteen of the alien species were present in the soil seed bank and sixteen alien species were recorded in the vegetation survey, with nine of these alien species being common to both. The single Acer representative that germinated in the soil seed bank study could not be identified at the species level and could be either native or alien. One significant, although not surprising, finding was that sixteen of the twenty alien species identified are considered to be invasive in Canada (White et al., 1993).

No plant species listed in Table 3 as Significant Species by the Ontario Natural Heritage Information Centre was present in either the soil seed bank study or the vegetation survey. In the vegetation survey, two locally significant species, Carex crawei and Carex 
Table 6: Species origin and growth pattern

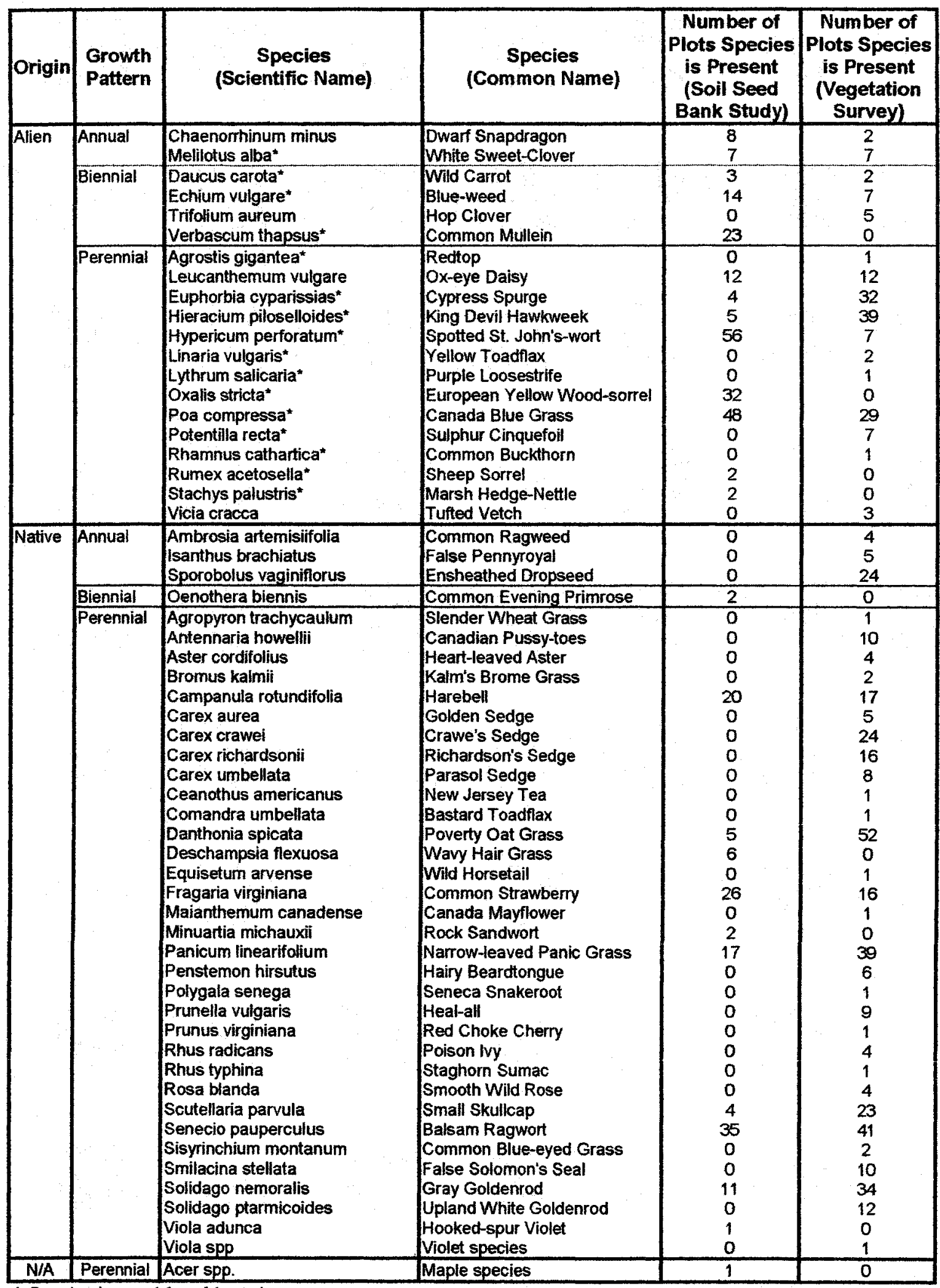

* Species is considered invasive. 
richardsonit, were present. In the soil seed bank study, Viola adunca was the only locally significant species that grew.

\begin{abstract}
Although the vegetation survey [Appendix D] contained more than twice the number of species that grew in the soil seed bank study, comparison of the number of species per plot between the two sets of data revealed a significant positive correlation at the 0.05 confidence level [Figure 6]. Spearman's correlation coefficient $(r s)$ was 0.300 with a 2tailed probability value $(p)$ of 0.0198 . This statistic indicates that as the number of species found in each plot for the vegetation survey increased, the number of species in corresponding plots in the soil seed bank study also increased.
\end{abstract}

In the soil seed bank study, there is a non-significant, weak positive correlation between the number of species per plot and the soil depth of that plot. However, in the vegetation survey, there was no correlation between the depth of the soil and the number of species present [Table 7]. The distribution of alien species between the soil seed bank study and the vegetation survey also show a trend [Figure 7]. The number of alien species in each plot in the soil seed bank study closely corresponds to the number of aliens found in the vegetation survey, although the specific alien species found in the soil seed bank study often differed from those recorded in the vegetation survey. As the number of alien species increased, species richness increased. 


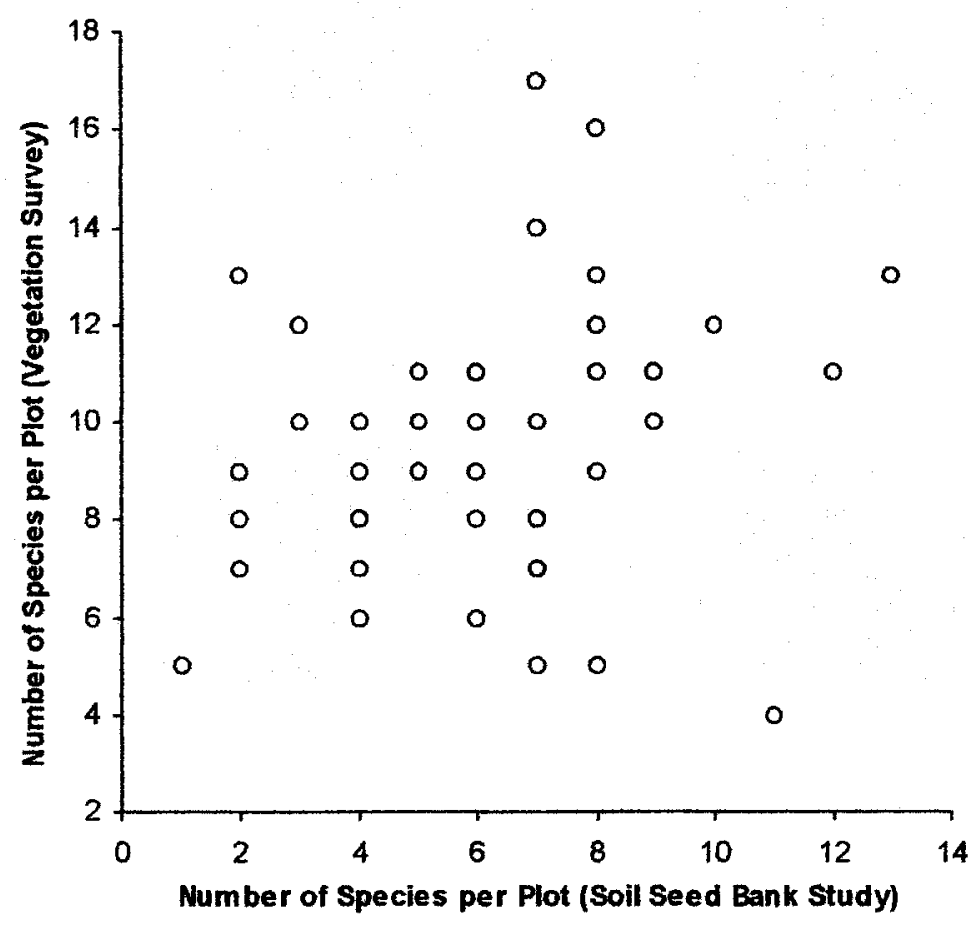

Figure 6: Comparison of species by plot between the soil seed bank study and the vegetation survey. NB: 60 plots are represented. Plots with the same values are superimposed; plots values can be found in Appendix E.

There was a significant positive correlation at the 0.05 confidence level between the amount of phosphorus in the soil and the number of species that germinated in the soil seed bank study ( $r s 0.405, p 0.026$ ). Phosphorus, an element that enables plants to grow and complete their life cycle, is primarily recycled through the decomposition of organic matter. Phosphorus compounds commonly found in soil are often insoluble and unavailable for plant consumption (Brady \& Weil, 1999). The significant correlation between phosphorus and species richness did not extend to the vegetation survey where no correlation was found. 
The remaining soil properties analysed did not show significant correlations with species richness in either the soil seed bank study or the vegetation survey.

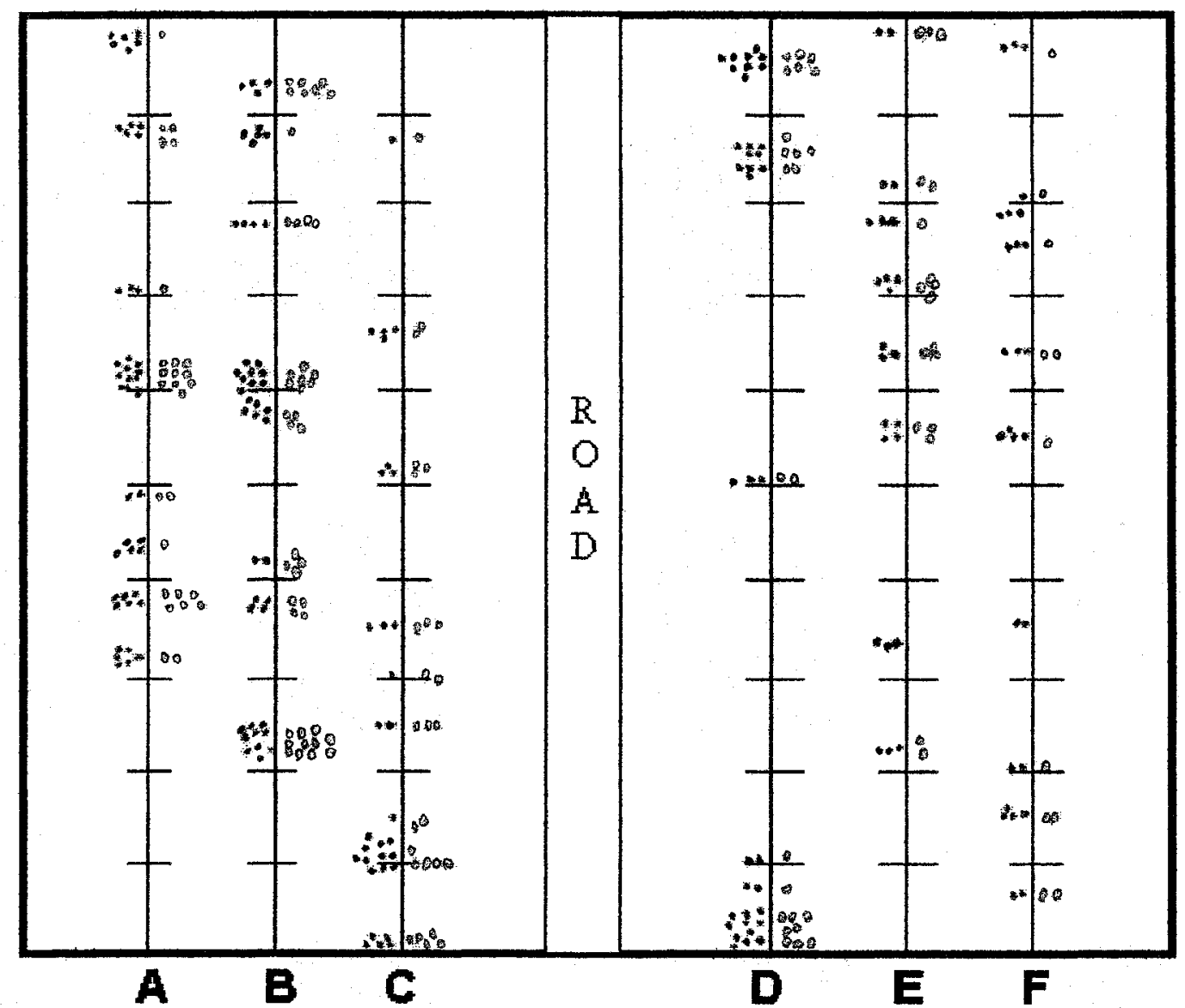

Figure 7: Distribution of alien species in the soil seed bank study and the vegetation survey. Dots in black to the left of each transect line represent the number of alien species that grew in the soil seed bank study. Grey dots to the right of the transect lines represent alien species that were recorded in the vegetation survey. Markers on the transect lines represent 10 metre intervals. 
Table 7: Table of Spearman's Correlation

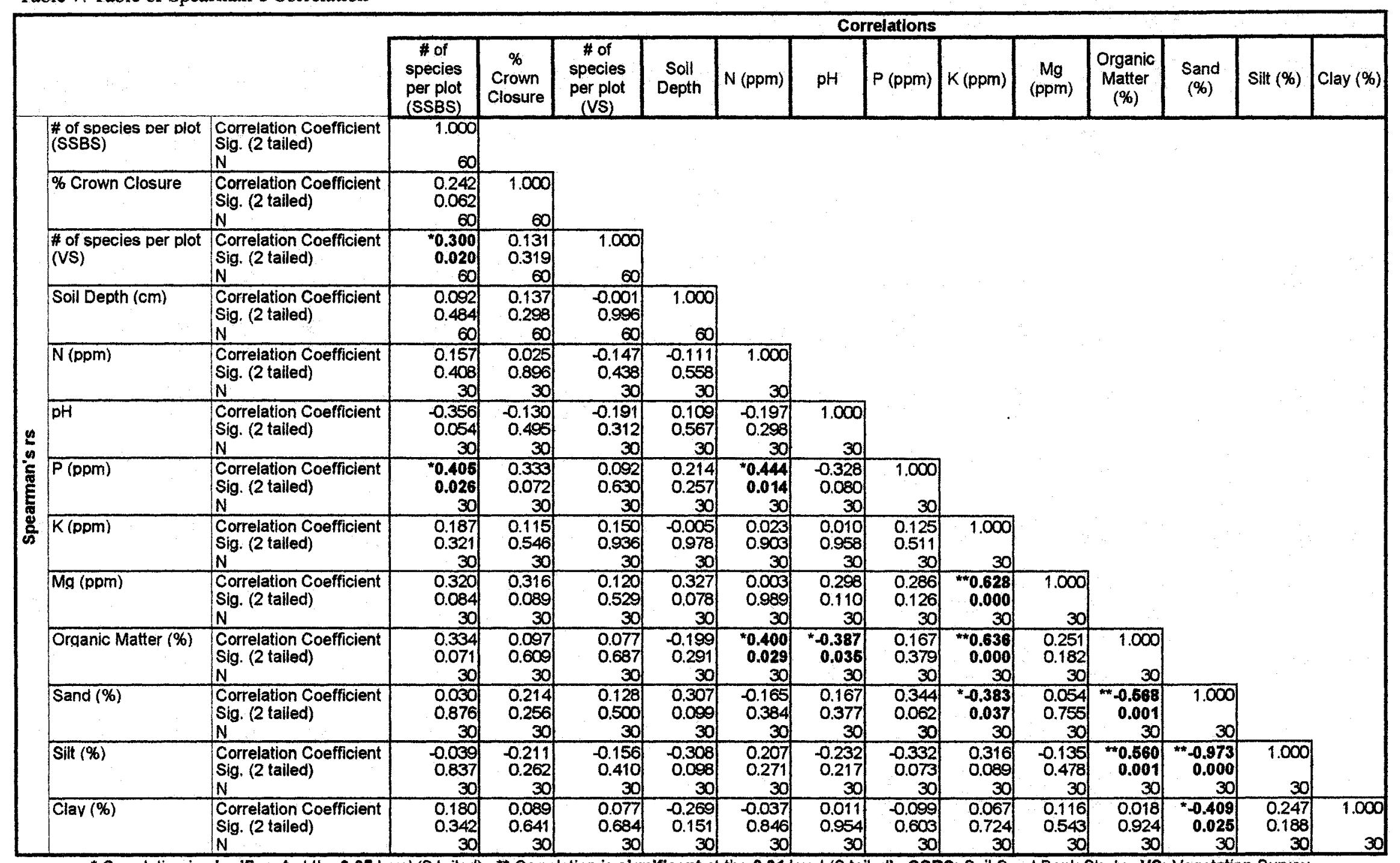

"Correlation is significant at the 0.05 level (2-tailed). " Correlation is significant at the 0.01 level (2-tailed). SSBS: Soil Seed Bank Study. VS: Vegetation Survey 
The per cent crown closure of Euphorbia cyparissias was not significantly correlated with the number of species in each plot in either the soil seed bank study or the vegetation survey [Table 7]. A weak positive correlation is counter intuitive because the presence of Euphorbia cyparissias has commonly been associated with a decrease in the number of species due to this plant's ability to aggressively compete and displace other species (Van Driesche, 2002).

Euphorbia cyparissias was subtracted from the number of species in each plot, where it was present, so that this species was not included in total species richness. Four plots in the soil seed bank study and 32 plots in the vegetation survey were affected by this change. With the elimination of Euphorbia cyparissias from the total number of species per plot, the Spearman's correlation changed from a positive trend to no correlation in both sets of data.

The Spearman's correlation was also recalculated for the total number of species by plot in the soil seed bank study to crown closure of Euphorbia cyparissias using only the 32 plots that contained Euphorbia cyparissias in the vegetation survey. The purpose of this calculation was to determine if the correlation strength and direction would change using only the plots that contained Euphorbia cyparissias, thereby detecting possible effects of Euphorbia cyparissias in the vegetation survey on the soil seed bank study. The results were similar to the findings when using all 60 plots. The correlation coefficient changed to $r s 0.31, p 0.083$ in the 32 plots from $r s 0.24, p 0.062$ in all 60 plots. Using the same 32 plots that contained Euphorbia cyparissias for the recalculation of Spearman's $r s$ for 
crown closure and the number of species per plot in the vegetation survey data, the $r s$ statistic changed from $0.131, p 0.319$ in all 60 plots to $r s-0.19, p 0.298$ indicating a shift from a positive trend to a negative trend. While non-significant, a negative trend is in the direction that would be anticipated indicating that as the per cent crown closure of Euphorbia cyparissias increases, species richness declines.

\subsection{Soil Analysis}

The soil parameters measured were organic matter, $\mathrm{pH}$, nitrogen, phosphorous, potassium, magnesium and the per cent of sand, silt and clay [Table 8]. The objective of analysing soils was to determine the fertility status of the site and whether the presence of Euphorbia cyparissias significantly affected or was significantly affected by differences in soil parameters within the site. Invasive species as a whole are believed to have a competitive advantage over native species because they usually germinate early, and thereby, co-opt the available resources in the soil to the disadvantage of the resident native species (Gordon, 1998; Heffernan, 1998; Higgins et al., 1999; Allendorf \& Lundquist, 2003).

The soils at the study site are classified texturally as sandy loam, with a mean sand content of $61 \%$. Silt contents have a mean value of $29 \%$ and clay content averages $10 \%$. The relatively high sand content and the low clay content coupled with the relatively shallow depth of the soil to bedrock limits the ability of the soil to hold both water and chemical nutrients in plant-available form (Brady \& Weil, 1999). In this study, both potassium $(r s-0.383, p 0.037)$ and the per cent of organic matter $(r s-0.568, p 0.001)$ 
decrease at a significant level as the percentage of sand increases. The level of nitrate in the soil also shows a negative trend when compared to sand content but not at a significant level (rs -0.165, p 0.384) [Table 7].

Table 8: Results of the analysed soil parameters by plot

\begin{tabular}{|c|c|c|c|c|c|c|c|c|c|c|}
\hline plot & $(2004)$ & $\begin{array}{l}\text { Organit } \\
\text { Matier } \\
(9)\end{array}$ & $p 1$ & Morare & (pong & (npm) & (rop) & 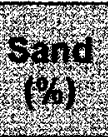 & $\sin (\%)$ & $6(x)$ \\
\hline A33 & 0 & 4.27 & 7.1 & 8 & 3 & 33 & 36 & 59 & 29 & 12 \\
\hline A37 & 0 & 5.82 & 69 & 14 & 3 & 38 & 35 & 59 & 31 & 10 \\
\hline A62 & 5 & 5.86 & 7.3 & 10 & 3 & 42 & 26 & 61 & 31 & 8 \\
\hline A7O & 10 & 9.07 & 71 & 11 & 3 & 43 & 27 & 50 & 40 & 10 \\
\hline B23 & 5 & 7.54 & 7.5 & 9 & 4 & 80 & 61 & 59 & 29 & 12 \\
\hline B38 & 5 & 4.73 & 72 & 5 & 4 & 44 & 30 & 67 & 23 & 10 \\
\hline B58 & 10 & 3.72 & 7.6 & 1 & 2 & 39 & 47 & 86 & 4 & 10 \\
\hline B60 & 20 & 5.77 & 7.5 & 6 & 3 & 51 & 68 & 80 & 10 & 10 \\
\hline $\mathrm{B} 61$ & 5 & 7.19 & 7.5 & 7 & 4 & 72 & 73 & 77 & 17 & 6 \\
\hline B78 & 5 & 6.64 & 7.4 & 8 & 1 & 30 & 44 & 57 & 31 & 12 \\
\hline C10 & 0 & 4.93 & 7.6 & 6 & 3 & 43 & 54 & 65 & 27 & 8 \\
\hline $\mathrm{C}_{25}$ & 10 & 4.69 & 7.7 & 10 & 2 & 39 & 52 & 67 & 23 & 10 \\
\hline C30 & 5 & 3.29 & 7.7 & 6 & 2 & 31 & 44 & 71 & 19 & 10 \\
\hline C35 & 5 & 4.44 & 7.6 & 7 & 2 & 38 & 51 & 57 & 31 & 12 \\
\hline C51 & 0 & 4.33 & 7.6 & 2 & 1 & 44 & 52 & 67 & 25 & 8 \\
\hline 067 & 0 & 5.83 & 7.5 & 9 & 1 & 52 & 46 & 52 & 38 & 10 \\
\hline C88 & 0 & 3.67 & 7.7 & 2 & 2 & 34 & 44 & 65 & 25 & 10 \\
\hline D50 & 5 & 7.13 & 7.4 & 5 & 2 & 69 & 57 & 47 & 43 & 10 \\
\hline D84 & 5 & 6.91 & 7.3 & 5 & 1 & 51 & 46 & 54 & 36 & 10 \\
\hline D85 & 5 & 5.33 & 76 & 7 & 0.5 & 57 & 46 & 51 & 39 & 10 \\
\hline D95 & 5 & 8.16 & 7.5 & 16 & 4 & 93 & 106 & 63 & 29 & 8 \\
\hline D96 & 5 & 6.72 & 76 & 15 & 4 & 92 & 93 & 55 & 35 & 10 \\
\hline E23 & 0 & 6.06 & 7.6 & 12 & 2 & 54 & 37 & 56 & 34 & 10 \\
\hline E63 & 5 & 4.79 & 7.6 & 0.5 & 1 & 61 & 49 & 58 & 30 & 12 \\
\hline E78 & 0 & 6.06 & 7.4 & 5 & 1 & 49 & 33 & 56 & 34 & 10 \\
\hline E98 & 5 & 5.17 & 7.5 & 1 & 1 & 46 & 37 & 64 & 28 & 8 \\
\hline $\mathrm{F} 16$ & 0 & 5.90 & 7.6 & 5 & 0.5 & 54 & 40 & 56 & 34 & 10 \\
\hline F36 & 0 & 4.77 & 7.6 & 10 & 1 & 30 & 24 & 69 & 23 & 8 \\
\hline F64 & 0 & 7.84 & 7.7 & 6 & 1 & 107 & 58 & 45 & 35 & 20 \\
\hline F79 & 0 & 5.47 & 7.6 & 6 & 1 & 31 & 26 & 57 & 35 & 8 \\
\hline
\end{tabular}

Typical well-drained soils contain between $1 \%$ to $6 \%$ organic matter (Tisdale \& Nelson, 1975; Brady \& Weil, 1999). The mean level of organic matter in the 30 samples was 
$5.73 \%$. Organic matter as it decomposes is a major source of available phosphorus, sulphur and nitrogen for plants. Results of the soil analysis show that as organic matter increases, so do levels of nitrate $(r s 0.400, p 0.029)$ and potassium $(r s 0.636, p<0.001)$. With an increase in organic matter, a soil's moisture holding capacity also increases (Brady \& Weil, 1999). This is significant for alvar habitats because they are subjected to extreme climatic fluctuations during the seasons. In spring, alvars are typically flooded or heavily saturated, but they commonly experience severe drought throughout much of the growing season. A soil with a higher percentage of organic matter would hold marginally more water, which should promote nutrient cycling and influence the germination of seeds in the soil seed bank (Leck et al., 1989).

\subsection{Soil Depth}

Soil depths ranged from $5 \mathrm{~cm}$ to $27.5 \mathrm{~cm}$ [Appendix F] with the majority of plots containing between $10 \mathrm{~cm}$ and $20 \mathrm{~cm}$ of soil [Figure 8]. No significant correlation was found between soil depth and species richness, per cent crown closure of Euphorbia cyparissias, soil nutrients or soil types [Table 7]. The statistical analysis showed no significant correlation between the per cent crown closure of Euphorbia cyparissias, a species well adapted, but not restricted to, shallow soils and soil depth 


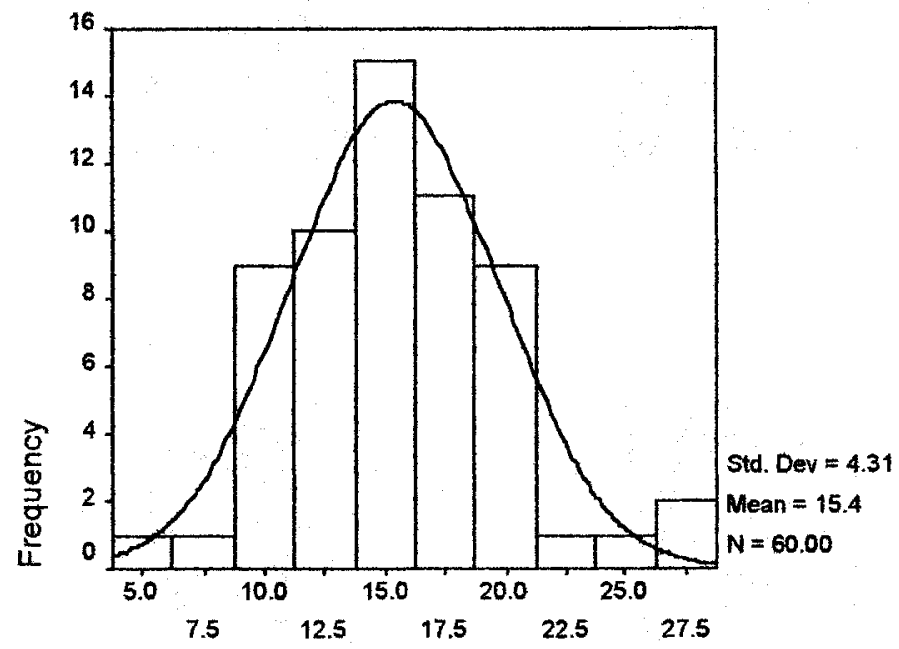

Soil Depth $(\mathrm{cm})$

Figure 8: Histogram showing the distribution of soil depth.

\subsection{Trees and Shrubs}

Most of the plant species identified by vegetative and soil seed bank studies qualify as herbaceous plants. Two tree species and five woody shrub species were found. The tree species (Acer spp.) in the soil seed bank study occurred in plot B61 where the soil depth was $20 \mathrm{~cm}$. No mature specimens of this species exist in close proximity to the site and it is unknown how the seed was transported there. If this seed had germinated under field conditions, it is improbable that it would reach maturity because the soil depth is too shallow. Rhus typhina was located in plot $\mathrm{C} 67$ with a soil depth of $17 \mathrm{~cm}$ during the vegetation survey. Rhus typhina is present on this site and has reached maturity outside of the study area. 
Five woody shrub species were recorded in the vegetation survey. Prumus virginiana and Rhamnus cathartica were both located in plot A37 with a soil depth of $14.8 \mathrm{~cm}$ and Ceanothus americanus was located in plot A33 with a soil depth of $15 \mathrm{~cm}$. Rhus radicans and Rosa blanda were the most common shrubs located in the study site with each species appearing in 4 plots. Rhus radicans was located in plots; A89, A97, B78 and F97 with soil depths of $6.5 \mathrm{~cm}, 10 \mathrm{~cm}, 16 \mathrm{~cm}$, and $11 \mathrm{~cm}$ respectively. Rosa blanda was located in plots A33, B41, D0 and F16 with soil depths in order $15 \mathrm{~cm}, 17 \mathrm{~cm}, 18 \mathrm{~cm}$ and $14 \mathrm{~cm}$. These shrub species are common throughout this section of the Burnt Lands Nature Reserve and have reached maturity directly outside of the study area. Rhamnus cathartica is the only shrub species that has reached maturity within the study area. 


\section{SYNTHESIS \& CONCLUSIONS}

The soil seed bank study and the vegetation survey were conducted for the purpose of gaining information that would assist in determining the extent to which native alvar species have been successful in surviving the presence of the invasive alien species, specifically, Euphorbia cyparissias. Information from this study also provides input for addressing the relative degree to which native species would be successful in surviving the disturbance that would be expected to accompany attempts to eradicate Euphorbia cyparissias from the site, by mechanical or other means, in the face of the potential success of the invasive species present in the soil seed bank study.

The 25 species that grew in the soil seed bank study consisted of 11 native species, 13 alien species and 1 Acer spp., unknown as to whether alien or invasive. Twelve of the alien species are known to be invasive in Canada (White et al., 1993). On the basis of the number of seeds that germinated, Hypericum perforatum displayed the most aggressive invasive potential with 590 individual plants growing across 56 plots during the soil seed bank study. Poa compressa, Oxalis stricta and Verbascum thapsus, respectively, were the next most widely distributed species appearing in 48,32 and 23 plots in the soil seed bank study. In the vegetation survey, the four invasive alien species that had the greatest germination in the soil seed bank study, Poa compressa, Hypericum perforatum, Oxalis stricta and Verbascum thapsus were present in $29,7,0$ and 0 plots respectively. The relative performances of these invasive species across the two studies may provide valuable clues to the ecosystem response following a substantial disturbance that might accompany the eradication of Euphorbia cyparissias. It might be expected that the 
responses to disturbance in the field situation, including the order of species appearance, the frequency of species appearance and the distribution of species that would germinate and grow may parallel those in the soil seed bank study.

If the above were the case, the first and most prolific species to germinate following disturbance would be Hypericum perforatum, a herbaceous perennial native to Europe that spreads through seed production and vegetatively through rhizomes. Hypericum perforatum is capable of producing more than 100000 seeds per plant annually and these seeds can remain viable in the soil seed bank in excess of 50 years (Kivilaan \& Bandursky, 1981; Crompton et al., 1988). This species is widely dispersed throughout Canada and has a preference for open habitats such as meadows, forest openings and agricultural lands (Harris et al, 1969; Crompton et al., 1988).

It is interesting, and possibly significant, that Hypericum perforatum was not dominant in the vegetation survey. While this species is an aggressive invader and prefers disturbed sites in open habitats, such as the study site, it was found growing in only 7 of the 60 plots. This is consistent with the observations of Catling and Brownell (1998), who conducted a vegetation survey of the former DND property of the Burnt Lands Nature Reserve and found that Hypericum perforatum appeared frequently but with low cover. The great success of this species in the soil seed bank study may have been caused by the repeated applications of fertiliser as demonstrated in a field experiment conducted by Catling in 1995, in addition to the temperature, moisture and light conditions provided in the greenhouse environment. Before fertiliser was added to the soil seed bank study, the 
Hypericum perforatum seedlings did not survive. The combined results of the soil seed bank study before fertilisation and the vegetation survey suggest that Hypericum perforatum may have some success as an initial coloniser at the study site, but that it is unlikely to be a strong competitor or exhibit long term dominance. Additional evidence to support this interpretation is that the section of the Burnt Lands where this study was conducted is highly disturbed by the public for recreational purposes such as horseback riding and the use of all-terrain vehicles. The limited presence of Hypericum perforatum in the vegetation survey suggests that the current level of disturbance has not facilitated aggressive invasion by Hypericum perforatum. Furthermore, Hypericum perforatum, while widely dispersed throughout Canada, is only recorded as highly problematic in southern British Columbia. In Eastern Canada, the literature reports this species as a minor problem with the appearance of individual plants or small infestations (Crompton et al., 1988; Harris et al., 1969).

Poa compressa was the second most prolific species to germinate in the soil seed bank study with 206 stems removed across 48 plots. This species is typically an early coloniser and is significant for its abundance in both the soil seed bank study and the vegetation survey where it appeared in 29 of the 60 plots examined. Poa compressa is considered an alien invasive species that is widely dispersed throughout Canada (Reader \& Bonser, 1993). Poa compressa prefers nutrient poor soils on clay or gravel in open habitats and is able to reproduce through seeds and rhizomes (Turkington, 1994). Poa compressa is able to resist invasion by other grasses once the initial colonies are established, however, this species matures late in the season and is intolerant of shade (Turkington, 1994). Early 
colonisers are able to compete with Poa compressa by providing shade, which leads to reduced seedling growth and survival. Furthermore, unlike many invasive alien species, Poa compressa has a host of predators including cattle, horses, and sheep and is susceptible to several pathogens, such as cocksfoot mild mosaic sobemovirus, Poa semilatent hardeivirus and wheat streak mosaic rymovirus (Turkington, 1994; Reader \& Bonser, 1993). Although Poa compressa is widely dispersed throughout the Burnt Lands, it is not seen as a major competitor or a threat to the native vegetation at this time (Catling \& Brownell, 1998).

Neither Oxalis stricta nor Verbascum thapsus appeared in the vegetation survey although their numbers were substantial in the soil seed bank study. Both of these species thrive in open places, along roadsides or abandoned fields and produce a large number of small persistent seeds (Niering \& Olmstead, 1995). While these species have the potential to become aggressive invaders at this site, their absence in the vegetation survey indicates that these species are not serious competitors at this time

Euphorbia cyparissias produced only 4 individual stems in 4 plots during the soil seed bank study but appeared in 32 plots during the vegetation survey. It is highly probable that the variant present in the Burnt Lands Nature Reserve is the sterile diploid that only reproduces vegetatively. Severed pieces of rootstock could have been missed during the hand cleaning of the soil, which could have led to the propagation of the 4 individuals that were found. Euphorbia cyparissias is a dominant invasive alien species at the study site and occupies a substantial portion of ground cover in relation to the other species 
present in the surface vegetation. Brunton (1985c) first noted the appearance of Euphorbia cyparissias at the Burnt Lands Nature Reserve in 1985. In almost twenty years since its documentation, this species has not proliferated to its full potential at this site despite its success in nearby surrounding areas (Stahevitch et al., 1988).

Euphorbia cyparissias is an invasive species that forms pure stands with extensive root networks and is known for its ability to displace other plant species (Stahevitch et al., 1988; Van Driesche, 2002). However, crown closure of Euphorbia cyparissias did not show any significant correlation with the other measured variables in this study. While species richness and nutrient levels were expected to decrease as the per cent crown closure of Euphorbia cyparissias increased, this trend was not observed. This trend could be explained by the fact that the extensive root system associated with Euphorbia cyparissias may act as a 'resource island' by retaining slightly higher levels of moisture and nutrients (Burke et al., 1998). Slight increases of water and nutrients in an impoverished environment would promote nutrient cycling, which would create more opportunities for the germination of viable seeds in the soil seed bank (Harper, 1977; Leck et al., 1989; Brady \& Weil, 1999).

Most nutrients in the soil showed only a very weak positive correlation with per cent crown closure of Euphorbia cyparissias. The most probable explanation for the lack of significant correlations with crown closure is that the per cent crown closure in most of the plots was relatively low and, therefore, not sufficient to have a significant impact on species richness or nutrient availability in the soil. If the crown closure of Euphorbia 
cyparissias increases at this site, nutrient levels and species richness may decrease significantly. The lack of significant correlation coefficients does not mean that Euphorbia cyparissias is not impacting the ecosystem; rather, the impacts are still relatively minor or not detectable at significant levels.

Precipitation levels during the two years over which this research was conducted were above average (Environment Canada, 2004), and recorded per cent of crown closure may appear to be misleading at the study site in comparison to per cent crown closure in dry years. In 1988, Stahevitch et al. documented the appearance of Euphorbia cyparissias in a lightly grazed pasture in Braeside, Ontario. The authors stated that Euphorbia cyparissias was dominant in dry summers comprising $56 \%$ of the total vegetation. In wet summers, Euphorbia cyparissias, at the same test site, accounted for only $26 \%$ of the total vegetation (Stahevitch et al., 1988). Furthermore, one of the Euphorbia cyparissias specimens that grew in the soil seed bank study was removed and transplanted into an individual planter. While in the greenhouse, this plant was watered daily. During this time, it formed one healthy spike that was $16.9 \mathrm{~cm}$ in height. It was then removed from the greenhouse and watered once a week for a period of 5 months. Two weeks after the frequency of watering was decreased, this plant began to form multiple rhizomes through the drainage holes in the pot and just below the soil surface. One month after the decrease in watering frequency, 9 rhizomes ranging from $8.2 \mathrm{~cm}$ to $56.4 \mathrm{~cm}$ in length had extended from the original parent plant (personal observation, 2004). While this species has a wide tolerance range for moisture, it is evident that it flourishes in drought-like conditions. 
Out of the eleven native species that grew in the soil seed bank study, four species are distinctively alvar species. Scutellaria parvula and Senecio pauperculus are two species that are primarily confined to alvar ecosystems in Ontario (Catling, 1995). Minuartia michauxii and Viola adunca are two additional alvar species that are commonly found in the boreal forest region and the sub-arctic. Although their range is not restricted to alvars, they are rarely found this far south except in alvar ecosystems (Brunton, 1985b, Brunton, 1985c). Campamula rotundifolia, Danthonia spicata, Deschampsia flexuosa, Panicum linearifolium, and Solidago nemoralis are common species that thrive in dry grassland ecosystems and alvars. Oenothera biennis and Fragaria virginiana are very common species that are not characteristic of alvars or dry grasslands.

The vegetation survey contained 12 plant species that are significant alvar species. Campanula rotundifolia, Danthonia spicata, Panicum linearifolium, Scutellaria parvula and Senecio pauperculus were identified in both the soil seed bank study and the vegetation survey as presented above. In addition to these species, the vegetation survey contained Sporobolus vaginiflorus, a species rare in Canada (White, 1979) and Ceanothus americanus which is common in Ontario but listed by the Ontario Natural Heritage Information Centre as a provincially significant species. Other species growing on the test site that are considered rare in the Ottawa-Carleton district and are primarily confined to alvar or dry grassland ecosystems include: Bromus kalmi, Carex crawei, Carex richardsonit, Penstemon hirsutus, and Polygala senega (White, 1979; Brunton, 1985b, Brunton, 1985c). 
The differences in species composition between the above ground vegetation and the plants that grew in the soil seed bank study are substantial but such differences are common and well represented in the literature on alvars and dry grassland ecosystems (Leck et al, 1989; Warr et al., 1993; Kirkhan \& Kent, 1997; Schaefer \& Larson, 1997, Stark et al., 2003). There was a total of fifty-one species, excluding the ten unidentified plants, present in the vegetation survey compared to twenty-five species that grew in the soil seed bank study. Thirty-three of the plant species identified in the vegetation survey did not appear in the soil seed bank study and nine of the species that grew in the soil seed bank study did not appear in the vegetation survey. There are several possible reasons for the absence of species in the soil seed bank study. The most likely reasons are that (1) seeds never became incorporated into the soil seed bank, (2) abiotic and biotic conditions supplied in the greenhouse did not favour germination for these species, (3) the seeds were not inherently persistent and did not survive the transition to the soil seed bank, or (4) the seeds suffered mortality by predators or pathogens. The nine species that were absent in the vegetation survey included both native and alien species. The four native species that were absent in the vegetation survey appeared in the soil seed bank study in only small numbers. These species may not have had favourable field conditions for germination or may simply have been missed during the random sampling of species in the vegetation survey. The four alien species that germinated in the soil seed bank study but were absent in the vegetation survey presumably had their seeds transported to this site where they have remained viable in the soil seed bank and were likely waiting for favourable conditions, provided in the greenhouse, to germinate. 
Annual species are cited as the largest contributors to soil seed banks because annuals have a relatively short life cycle to reproduce so they tend to produce an abundance of persistent seeds (Silvertown, 1982; Leck et al., 1989). Only two annual species germinated in the soil seed bank study; likewise, there was a distinct paucity of annuals in the above ground vegetation at the study site.

The soil was chemically analysed to determine if the presence of Euphorbia cyparissias altered soil nutrient levels. Results from this study showed no significant differences between plots that contained Euphorbia cyparissias when compared to plots void of this species. Soils in alvar ecosystems are characterised by shallow sandy soils that have low nutrient levels and a low moisture holding capacity. In addition, alvar soils in this region are subjected to significant seasonal climatic fluctuations (Brunton, 1988; Brownell \& Riley, 2000). The soils at the study site contain notably fewer nutrients when compared to the study performed by Stark et al. (2003) on the Bruce Peninsula open pavement alvar ecosystems. However, species observed in the vegetation survey did not exhibit some of the signs of stress typical of nutrient deficiencies, such as discolouration or the inability to complete their life cycle (Tisdale \& Nelson, 1975; Brady \& Weir, 1999). The lack of these stress indicators suggests that these species are well adapted to, or at least tolerant of, the relatively harsh environmental conditions presented at the study site.

During the initial phase of the soil seed bank study a small number of seedlings began to germinate and grow. When these seedlings were only a few millimetres in height, they 
stopped growing and began to turn yellow and red indicating insufficient nutrients to support the plants' survivability and continued growth. After the soils were fertilised, species began to recover and the emergence of new seedlings was observed. Low nutrient content in the soil seed bank study could have three reasons. First, the nutrients in the soil were already naturally low. Second, the soils were planted in plastic trays with drainage holes and watered daily, which could have leached nutrients from the soil. Third, the soils were cleaned of debris and organic matter, which acts as a storehouse for nutrients in the soil (Burke et al., 1998; Grime et al., 1997; Kohler et al., 2001; Critchley et al., 2002). Without the debris and organic matter present in the soil, organic matter decomposition would be limited, exacerbating a deficiency of nutrients to support the growth of plant seedlings.

The results of this study are consistent with other soil seed bank studies conducted on alvar ecosystems. Species in the soil seed bank differed dramatically from above ground vegetation; moreover, variables tested for correlation such as crown cover, soil depth, and nutrient levels did not produce correlation coefficients at significant levels (Bakker et al., 1996; Stark et al., 2003). The study conducted by Stark et al. (2003) showed that although soil depths and nutrients are suitable for the growth of woody and tree species that surround the alvars on the Bruce Peninsula, the local alvar soil seed bank study did not contain seeds from the adjacent forest. The lack of invasion by both alien invasive plant species and tree species into alvar ecosystems despite favourable conditions for such invasions gives rise to the natural processes of alvar ecosystems. The absence of significant correlation coefficients would suggest that something other than the measured 
variables are naturally maintaining alvars or, alternately, repelling invasion. Burke et al. (1998) suggests that water, not nutrients, is the key factor for stability and the ability to recover from disturbance in dry grassland ecosystems. These authors hypothesise that
"the strong limitation of soil water leads to complete (though uneven) occupation of the soil by roots, but insufficient resources to support continuous above-ground plant cover. Discontinuous above ground cover leads to strong biological and physical forces that result in the accumulation of soil materials beneath individual plants in resource islands... Resource islands may have a great deal of significance as a index of recovery from disturbance, an indicator of ecosystem stability or harbinger of desertification, or because of possible feedbacks to plant establishment" (Burke et al., 1998, pg. 124).

Soil moisture was not measured in this study but undoubtedly it plays a significant parallel role in alvar ecosystems. Furthermore, if the soil is completely occupied by roots that create 'resource islands', then it is possible that alien invasive plant species are not able to compete in alvar ecosystems below ground. This may account for the lack of success of alien invaders above ground but their relative success in the soil seed bank study after the soil was cleaned of roots and debris.

The study of invasive alien plant species is an important field of investigation for understanding and thereby mitigating some of the harmful effects these species cause to the functioning of natural ecosystems. Individual plants, plant communities, biotic and abiotic processes interact to form a highly complex system that is difficult to study. Although ecosystem interactions are significant aspects of any ecosystem, the reduction of complexities allows for the investigation of possible relations that can compliment ecosystem studies. The study of a specific invasive alien plant species and its interactions 
in a particular ecosystem has the ability to form a foundation for understanding the effects invasive alien plant species pose on natural ecosystem processes specific to an ecosystem type. The Burnt Lands Nature Reserve is a highly diverse ecosystem with multiple distinct communities ranging from bare limestone pavement to forested communities.

Considering the relatively high numbers of alien invasive species in the soil seed bank study, the study site would not normally be considered a good candidate for self-recovery of the native species in the soil seed bank should the surface Euphorbia cyparissias be removed. The lack of several native alvar species in the soil seed bank study may indicate that the native alvar species present in the above ground vegetation are relying on underground roots and rhizomes to maintain their presence (Burke et al., 1998; Rosburg, 2001). The desired native alvar species that rely on roots and rhizomes may be adversely affected by the removal of Euphorbia cyparissias from the surface vegetation. Disturbance is a natural process necessary for the regeneration of plant communities (Perrins et al., 1993; Luken, 1997) but the type of disturbance that would promote the regeneration of desired species while discouraging invasive alien species is not known. The study site is highly disturbed by the public for recreational purposes and the invasive alien species that appeared in the soil seed bank study have not fully taken advantage of such disturbances. Future research that examines different types of disturbance and their effect on the existing plant communities is necessary prior to the removal of Euphorbia cyparissias from this site. 


\subsection{Limitations}

The soil seed bank study was conducted in a safe-site (greenhouse) where temperature, light and water was supplied at a fixed rate each day. Safe-sites are known to promote species propagation but can also impose limitations to the study. One possible limitation is that species in the soil seed bank may not have germinated due to the lack of specific biotic and/or abiotic conditions presented. For example, alvar ecosystems contain many ephemerals that can be easily missed in a vegetation survey because these species only germinate under very specific conditions and complete their life cycle in short periods of time. Furthermore, fire is a historically natural process on North American alvar ecosystems that is necessary for the propagation of some alvar species, such as the rare alvar perennial Astragalus neglectus (Catling et al., 2001; Catling \& Sinclair, 2002). Conditions provided in the greenhouse may not have been suitable for the germination of all species in the soil seed bank. Conducting a seed assay where the soil is washed over a $0.2 \mathrm{~mm}$ sieve of mesh to collect the seeds in the soil and then test for viability would have eliminated this unknown (Silvertown, 1982; Bekker et al., 1997; Bekker et al., 1998). Alternately, a soil seed bank study could have been conducted on site, thereby, eliminating bias found in safe-site conditions (Silvertown, 1982; Graham \& Hutchings, 1988; Akinola et al., 1998).

Based upon the research conducted by Stahevitch et al.(1988), coupled with personal observations of the drought tolerant nature of Euphorbia cyparissias, it is reasonable to assume that there is a possibility that other species in this ecosystem may have similar preferences for drought-like conditions. Sufficient amounts of water, light and nutrients 
are essential for the propagation of most plant species (Harper, 1977; Silvertown, 1982; Begon et al., 1990). Although the soil samples for the soil seed bank study were placed in plastic trays with drainage holes, the daily watering of these samples may have limited germination in some species. Experimenting with water levels among duplicate samples would have eliminated this unknown.

The soil seed bank study took place over one growing season and the vegetation survey was conducted once during one growing season. Subsequent studies that extended beyond one growing season would eliminate anomalies, allow the researcher to re-survey the study area for possible expansion of target alien invasive species as well as gain a better understanding of alvar ecosystems through successive studies. For example, the year the vegetation survey was conducted was unusually wet which may have created a non-average representation of per cent of crown closure for Euphorbia cyparissias.

\subsection{Future Research}

Future research on alvar ecosystems in relation to invasive alien plant species and the effects that these species may have at the soil seed bank level would provide a valuable source of information to scientists as well as those involved with ecological restoration efforts. Further examination of the soil seed bank may reveal possible successive plant communities in a post-disturbed ecosystem, the number and type of viable native seeds, and the ratio of native seeds to invasive alien seeds. Because alvar ecosystems contain many rare and endangered plant species, viable native plant seeds present in the soil seed bank may be used in ecological restoration efforts for the preservation of these species. 
A continuation of the research conducted in this thesis might include an in-situ soil seed bank study or a laboratory soil seed bank study that would include multiple soil samples from the same plot but different applications of water, nutrients, and light. This is the second soil seed bank study conducted on alvar ecosystems in North America. Further soil seed bank studies on alvar ecosystems would provide a base for comparisons of results and perhaps a better understanding about how these systems operate.

Another area for future inquiry is the removal of invasive alien plant species in alvar ecosystems. Using multiple methods for removing invasive species followed by annual monitoring to detect ecosystem responses to both the method of removal and its reaction to the disturbance created by removal would provide valuable insight for conservation managers trying to restore and preserve these ecosystems. Monitoring would need to be conducted over several years to assess the rate of success for the removal method and for determining which plant communities would grow and evolve within the alvar in the absence of invasive alien plants.

Future research should include an extension of measured variables such as moisture content levels and above and below ground competition experiments. Finally, a host of restoration techniques applied to the removal of Euphorbia cyparissias would promote a more elaborate understanding of the alvar successional plant communities in addition to alvar ecosystem response to disturbance and ability to self-recover through the soil seed bank. 


\section{WORKS CITED}

Akinola, M., K. Thompson and S. Buckland. 1998. Soil seed bank of an upland calcareous grassland after 6 years of climate and management manipulations in The Journal of Applied Ecology, Vol 35: 4.

Allendorf, F. and L. Lundquist. 2003. Introduction: Population Biology, Evolution, and Control of Invasive Species in Conservation Biology, Vol 17: 1.

APWG. 1999. Plant Conservation Alliance, Alien Plant Working Group. On-line resource located at http:/www.nps.gov/plants/alien/bkgd.html. Site accessed January, 2003.

Baker, H. 1965. Characteristics and modes of origin of weeds in $H$. Baker and $G$. Stebbins (editors) The genetics of colonizing species. Academic Press: London.

Bakker, J., E. Bakker, E. Rosen, G. Verweij and R. Bekker. 1996. Soil seed bank composition along a gradient from dry alvar grassland to Juniperus Shrubland in Journal of Vegetation Science, Vol 7.

Barker, P. 2001. A Technical Manual for Vegetation Monitoring. Resource Management and Conservation, Department of Primary Industries, Water and Environment. Resource Management and Conservation, Hobart: Tasmania.

Barrett, S. and B. Richardson. 1986. Genetic attributes of invading species in Ecology of Biological Invasions (Edited by Groves R. and J. Burdon). Australian Academy of Science: Canberra.

Baskin, C and J. Baskin. 1998. Seeds: Ecology, Biogeography and Evolution of Dormancy and Germination. Academic Press: San Diego, USA.

Begon, M, J. Harper, and C. Townsend. 1990. Ecology: Individuals, Populations and Communities. Blackwell Scientific Publication: Oxford.

Bekker, R., G. Verweij, R. Smith, R. Reine, J. Bakker and S. Schneider. 1997. Soil Seed Banks in European Grasslands: Does Land Use Affect Regeneration Perspectives? in The Journal of Applied Ecology, Vol 34: 5.

Bekker, R, I. Knevel, J. Tollowin, E. Troost and J. Bakker. 1998. Soil nutrients input effects on seed longevity: A burial experiment with meadow species in Functional Ecology, Vol 12: 4.

Belcher, J., P. Keddy, and P. Catling. 1992. Alvar vegetation in Canada: a multivariate description at two scales in Canadian Journal of Botany, Vol 70. 
Berenson, M., D. Levine and D. Rindskopf. 1988. Applied Statistics-A first course. Prentice-Hall Inc: : New Jersey.

Bouchard, P. and T. Wheeler. 1997. Anthropoids of Alvar habitats. Newsletter of the Biological Survey of Canada, Vol 16: 2.

Bradshaw, A. 1997. What do we mean by restoration? in Restoration Ecology and Sustainable Development (Edited by Urbanska). Cambridge University Press: UK.

Brady, N. and R. Weil. 1999. The Nature and Properties of Soils, $12^{\text {th }}$ Edition. PrenticeHall Inc.: New Jersey.

Brownell, V. and J. Riley. 2000. The Alvars of Ontario: Significant Alvar Natural Areas in the Ontario Great Lakes Region. Federation of Ontario Naturalists: Ontario, Canada.

Brunton, D. 1985b. Recent significant plant records from the Ottawa District, Part 2. Pickerel-weed to Bean Family in Trail and Landscape, Vol 19: 2.

Brunton, D. 1985c. Recent significant plant records from the Ottawa District, Part 3. Wood-sorrel family to Composite Family in Trail and Landscape, Vol 19: 3.

Brunton, D. 1988. Nature and Natural Areas in Canada's Capital. The Ottawa Citizen and the Ottawa Field-Naturalist Club: Ottawa, ON.

Burke, M. and J. Grime. 1996. An experimental study of plant community invasibility in Ecology, Vol 77.

Burke, I., W. Lauenroth, M. Vinton, P. Hook, R. Kelly, H. Epstein, M. Aguiar, M. Robles, M. Aguilera, K. Murphy and R. Gill. 1998. Plant-Soil interactions in temperate grasslands in Biogeochemistry, Vol 42.

Case, T. 1991. Invasion resistance, species build-up and community collapse in metapopulation models with interspecies competition in Biological Journal of the Linnean Society, Vol 42.

Catling, P. 1995. The Extent of Confinement of Vascular Plants to Alvars in Southern Ontario in Canadian Field Naturalist, Vol 109: 2.

Catling, P. and V. Brownell. 1995. A review of the alvars of the Great Lakes region: distribution, composition, biogeography and protection in Canadian Field-Naturalist, Vol 109.

Catling, $\mathbf{P}$. and V. Brownell. 1998. Importance of fire in the maintenance of distinctive, high biodiversity plant communities on alvars - evidence from the Burnt Lands, eastern Ontario in The Canadian Field Naturalist, Vol 112: 4. 
Catling, P., A. Sinclair and D. Cuddy. 2001. Vascular Plants of a Successional Alvar Burn 100 Days After a Severe Fire and their Mechanisms of Re-establishment in Canadian Field-Naturalist, Vol 115: 2.

Catling, P. and A. Sinclair. 2002. Initial beneficial effects of fire and bulldozing on Neglected Milkvetch, Astragalus neglectus, in an Eastern Ontario Alvar Woodland in Canadian Field-Naturalist, Vol 116: 4.

Conover W. 1980. Practical Non-parametric Statistics - 2nd Edition. Prentice-Hall Inc.: US.

Critchley, C, B. Chambers, J. Fowbert, R. Sanderson, A. Bhogal and S. Rose. 2002. Association between lowland grassland plant communities and soil properties in Biological Conservation, Vol 105.

Crompton, C., I. Hall, K. Jensen and P. Hildebrand. 1988. The biology of Canadian weeds (Hypericum perforatum L.) in Canadian Journal of Plant Science, Vol 68.

Cronk, Q. and J. Fuller. 1995. Plant Invaders. Chapman and Hall: London.

Cuddy, D. 2003. Personal Communications. Don Cuddy is a former Ontario Ministry of Natural Resources employee who has conducted research at the Burnt Lands Nature Reserve for more than 25 years.

Elton, C. 1958. The Ecology of Invasions by Animals and Plants. Methuen: London.

Environment Canada. 2004. Canadian Climate Normals or Averages. On-line resource located at

htp://www. climate weatheroffice.ec.gc.ca/climate normals/index e.hrml. Site accessed on August $12,2004$.

ESRI, 2005. ESRI Canada. On-line resource located at www esricanadacom. Site accessed on January 13, 2005.

Evans, E. 2003. Economic Dimensions of the Problem of Invasive Species. EDIS document number FE386 published by the Department of Food and Resource Economics: Florida, USA.

Fox, M. and B. Fox. 1986. The susceptibility of natural communities to invasion in Ecology of Biological Invasions (Edited by Groves R. and J. Burdon). Australian Academy of Science: Canberra.

Gilbert, O. and P. Anderson. 1998. Habitat Creation and Repair. Oxford University Press: Oxford. 
Graham, D. and M. Hutchings. 1988. A Field Investigation of Germination from the Seed Bank of a Chalk Grassland Ley on Former Arable Land in The Journal of Applied Ecology, Vol 25: 1.

Grime, J., K. Thompson, R. Hunt, J. Hodgson, J. Cornelissen, I. Rorison, G. Hendry, T. Ashenden, A. Askew, S. Band, R. Booth, C. Bossard, B. Campbell, J. Cooper, A. Davison, P. Bupta, W. Hall, D. Hand, M. Hannah, S. Hillier, D. Hodkinson, A. Jalili, Z. Liu, J. Mackey, N. Matthews, M. Mowforth, A. Neal, R. Reader, K. Reiling, W. RossFraser, R. Spencer, F. Sutton, D. Tasker, P. Thorpe, and J. Whitehouse. 1997. Integrated screening validates primary axes of specialisation in plant in Oikos, Vol 79.

Goodwin,B. A. McAllister and L. Fahrig. 1999. Predicting Invasiveness of Plant Species Based on Biological Information in Conservation Biology, Vol 13: 2.

Grooves, R. and F. DiCastri. 1991. Biogeography of Mediterranean Invasions. Cambridge University Press: Cambridge.

Gordon, D. 1998. Effects of Invasive, Non-indigenous Plant Species on Ecosystem Processes: Lessons from Florida in Ecological Applications, Vol 8: 4.

Haber, E, 2002. Invasive Species of Canada Survey 2002: An assessment of resources and needs. Canadian Wildlife Service: Ottawa, Canada.

Harper, J. L. 1977. Population Biology of Plants. Academic Press Inc: London.

Harris, P., D. Peschken and J. Milroy. 1969. The status of biological control of the weed Hypericum perforatum in British Columbia in The Canadian Entomologist, Vol 101.

Heffernan, K. 1998. Managing Invasive Alien Plants in Natural Areas, Parks, and Small Woodlands. Natural Heritage Technical Report 98-25. Virginia Department of Conservation and Recreation, Division of Natural Heritage: Richmond, Virginia.

Higgens, S., D. Richardson, R. Cowling and T. Trinder-Smith. 1999. Predicting the Landscape-Scale Distribution of Alien Plants and Their Threat to Plant Diversity in Conservation Biology, Vol 13: 2.

Hoaglin, D., F. Mosteller, and J. Tukey, J. 1983 . Understanding Robust and Exploratory Data Analysis. John Wiley and Sons: New York.

Hobbs, R. and L. Huenneke. 1992. Disturbance, Diversity and Invasion: Implications for Conservation in Conservation Biology, Vol 6: 3.

Hobbs, R. and S. Humphries. 1995. An Integrated Approach to the Ecology and Management of Plant Invasions in Conservation Biology, Vol 9: 4. 
Holloway, M. 2000. Nurturing Nature in Environmental Restoration. Ethics, Theory and Practice (Edited by Throop, W). Humanity Books: New York.

International Alvar Conservation Initiative. 1995. Alvar Working Group (unpublished).

Jones, D. 2000. Vegetation Measurement Methods Comparison. Center for Ecological Management of Military Lands: Colorado: USA.

Kirkham, F and M. Kent. 1997. Soil Seed Bank Composition in Relation to the Above Ground Vegetation in Fertilized and Unfertilized Hay Meadows on a Somerset Peat Moor in The Journal of Applied Ecology, Vol 34: 4.

Kivilaan, A and R. Bandursky. 1981. The one-hundred year period for Dr. W. Beal's seed viability experiment in the American Journal of Botany, V 68.

Kohler, B., P. Ryser, S. Gusewell and A. Gigon. 2001. Nutrient availability and limitation in traditionally mown and in abandoned limestone grasslands: a bioassay experiment in Plant and Soil, Vol 230.

Leck, M., V. T. Parker, and R. Simpson (editors). 1989. Ecology of Soil Seed Banks. Academic Press Inc.: New York.

Lehman, L. 1975. Non-parametrics: Statistical methods based on ranks. Holden-Day: San Francisco, USA.

Levine, J. and C. D'Antonio. 1999. Elton revisited: a review of evidence linking diversity and invasibility in $O I K O S$, Vol 87.

Lonsdale, W. 1999. Global Patterns of Plant Invasions and the Concept of Invasibility in Ecology, Vol 80: 5.

Luken, J. 1997. Management of Plant Invasions: Implicating Ecological Succession in Assessment and Management of Plant Invasions (Edited by Luken, J. and J. Thieret). Springer - Verlag New York Inc: New York.

McNeely, J. 2000. Invasive Species: A Costly Catastrophe for Native Biodiversity in Best Management Practices for Preventing and Controlling Invasive Alien Species (Edited by: Preston, G., A. Brown, and E. vanWyk). Working for Water Programme: South Africa.

McNeely, J., H. Mooney, L. Neville, P. Schei and J. Waage. 2001. Global Strategy on Invasive Alien Species. IUCN Publication Services: Cambridge.

Mooney, H. and J. Drake. 1986. Ecology of Biological Invasions of North America and Hawaii. Springer-Verlag: New York. 
Newsome, A. and I. Noble. 1986. Ecological and physiological characters of invading species in Ecology of Biological Invasions (Edited by Groves R. and J. Burdon).

Australian Academy of Science: Canberra.

Niering, N. and N. Olmstead. 1995. National Audubon Society Field Guide to North American Wildflowers - Eastern Region. Alfred A. Knopf Inc.: New York.

Ontario Ministry of Agriculture and Food. 2003. Ontario Weeds: Cypress Spurge. Online resource located at www.gov.on.ca/OMAFRA. Site accessed on August 11, 2003.

Ontario Ministry of Natural Resources. 2000. Natural Heritage Area-Life Science Checksheet. Internal Documentation (unpublished).

Ontario Vegetation Management Association (OVMA). 2003. Cypress Spurge. . On-line resource located at www ovma.on.ca:Weeds/spurge.hum. Site accessed on August 11, 2003.

Perrins, J., A. Fitter and M. Williamson. 1993. Population biology and rates of invasion of three introduced Impatiens species in the British Isles in The Journal of Biogeography, Vol 20.

Plant National Database (U.S.A.), 2005. On-line resource located at www.plants.usda.gov/ Site accessed on January 13, 2005.

Primack, R. 1993. Essentials of Conservation Biology. Sinauer Associates Inc.: USA.

Rana, B. 1998. Damaged Ecosystems and Restoration. World Scientific: Singapore.

Reader, R. and S. Bonser. 1993. Control of plant frequency on an environmental gradient: Effects of abiotic variables, neighbours, and predators on Poa pratnsis and Poa Compressa in the Canadian Journal of Botany, Vol 71.

Rejmanek, M. and D. Richardson. 1996. What Attributes Make Some Plant Species More Invasive? in Ecology, Vol 77: 6.

Richardson, D. and W. Bond. 1991. Determinants of Plant Distribution: Evidence from Pine Invasions in American Naturalist, Vol 137: 5.

Roberts, H. 1981. Seed banks in the soil. Advances in Applied Biology. Academic Press: Cambridge.

Rosburg, T. 2001. Secrets of the seed bank: Tiny clues to a landscape 's past and future. Iowa Natural Heritage quarterly magazine, Winter Issue.

Schaefer, C and D. Larson. 1997. Vegetation, environmental characteristics and ideas on the maintenance of alvars on the Bruce Peninsula, Canada in Journal of Vegetation Science, Vol 8. 
Scudder, G. 2002. Alien Invaders: An Introduction in Alien Invaders in Canada's

Waters, Wetlands, and Forests (Edited by: Claudi, R., P. Nantel and E. Muckle-Jeffs).

Canadian Forest Service: Ottawa.

Silvertown, J. 1982. Introduction to Plant Population Ecology. Longman Group Limited: New York.

Smith, R.L. 1992. Elements of Ecology, Third Edition. Harper Collins Publishers: USA.

Solbrig, O., S. Jain, G. Johnson and P. Raven. 1979. Topics in Plant Population Biology. Columbia University Press: New York.

Sregel, S, and N.Castellan. 1988. Nonparametric Statistics for the Behavioral Sciences. McGraw-Hill Publishers: Columbus, $\mathrm{OH}$.

Stahevitch, C., C. Crompton and W. Wojtas. 1988. The Biology of Canadian Weeds. 85. Euphorbia cyparissias L. in the Canadian Journal of Plant Science, Vol 68.

Stark, K., J. Lundholm and D. Larson. 2003. Relationships between seed banks and spatial heterogeneity of North American alvar vegetation in Journal of Vegetation Science, Vol 14.

Swincer, D. 1986. Physical characteristics of sites in relation to invasions in Ecology of Biological Invasions (Edited by Groves R. and J. Burdon). Australian Academy of Science: Canberra.

Throop, W. 2000. Environmental Restoration. Ethics, Theory and Practice. Humanity Books: New York.

Tisdale, S. and W. Nelson. 1975. Soil Fertility and Fertilizers. Macmillan Publishing Company: USA.

Tukey, J. 1977. Exploratory Data Analysis. Addison-Wesley Inc.: Cambridge.

Turkington, R. 1994. Effect of propagule source on competitive ability of pasture grasses: Special dynamics of six grasses in simulated sward in the Canadian Journal of Botany, Vol. 72 .

US Fish and Wildlife Service. 2003. A Comparison of the Most Commonly Employed Vegetation Data Collection Methods. . On-line resource located at http//fire. Iffws.gov/ifcc/monitor/RefGuide/daubenmire_method.html. Site accessed on May 6, 2003.

Van Driesche, R, 2002. Biological Control of Invasive Plants in the Eastern United States. USDA Forest Service: Publication FHTET-2002-04. 
Warr, S., K. Thompson and M. Kent. 1993. Seed banks as a neglected area of biogeographic research: a review of literature and sampling techniques in Progress in Physical Geography, Vol 17:3.

White, D.J. 1979. Burnt Lands Alvar in Trail and Landscape, Vol 13.

White, D.J., E. Haber and C. Keddy. 1993. Invasive Plants of Natural Habitats in Canada: An Integrated Review of Wetland and Upland Species and Legislation Governing their Control. Canadian Wildlife Service, Environment Canada: Ottawa.

Wilson, E. 1990. Threats to Biodiversity in Managing Planet Earth. W.H. Freeman and Company: U.S.A.

With, K. 2001. The Landscape Ecology of Invasive Spread in Conservation Biology, Vol 16:5.

Woods, K. 1997. Community Response to Plant Invasion in Assessment and Management of Plant Invasions (Edited by Luken, J. and J. Thieret). Springer - Verlag New York Inc: New York. 


\section{Appendix A: Distribution of Measured Variables}
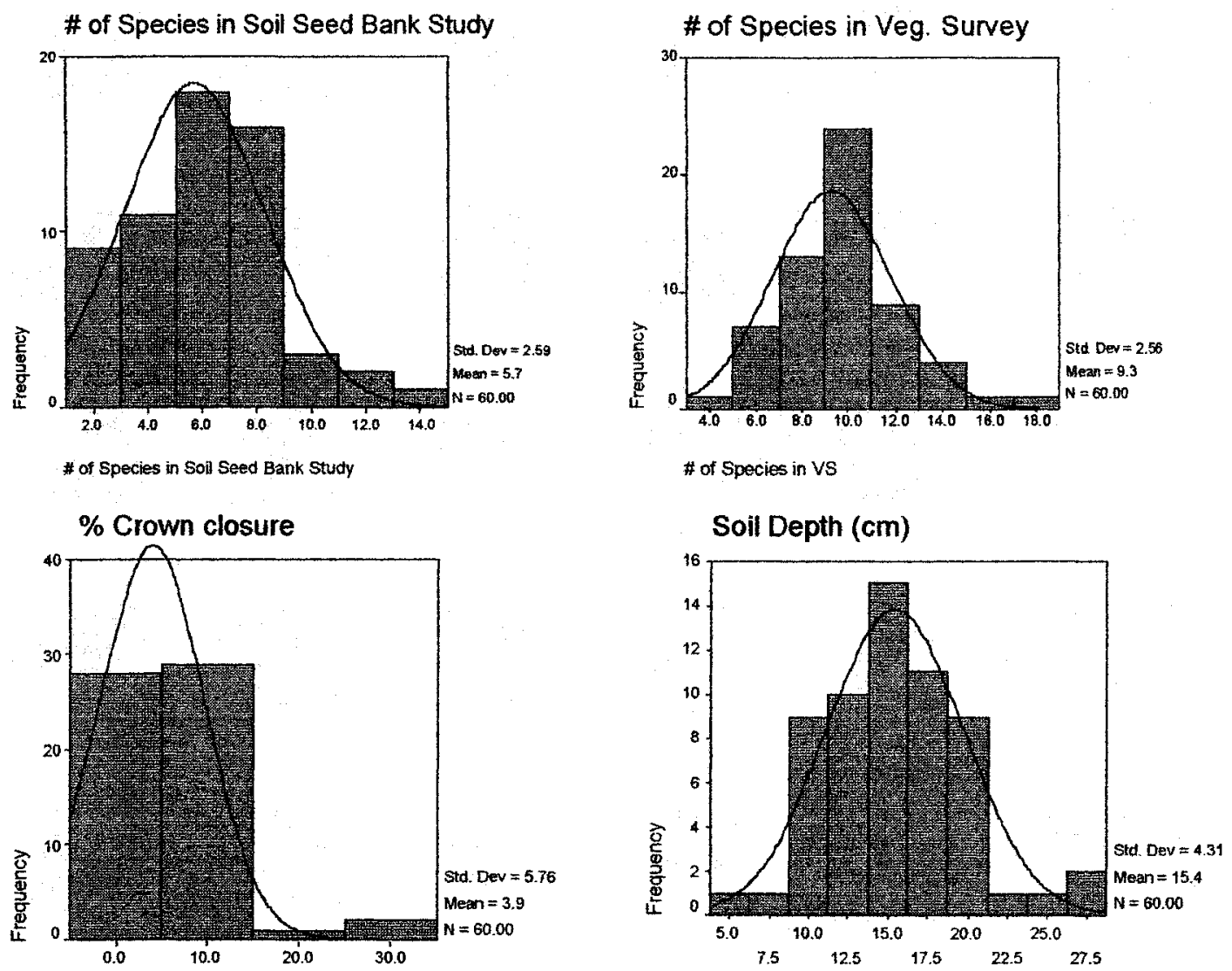

$\%$ Crown closure

Soil Depth (cm)
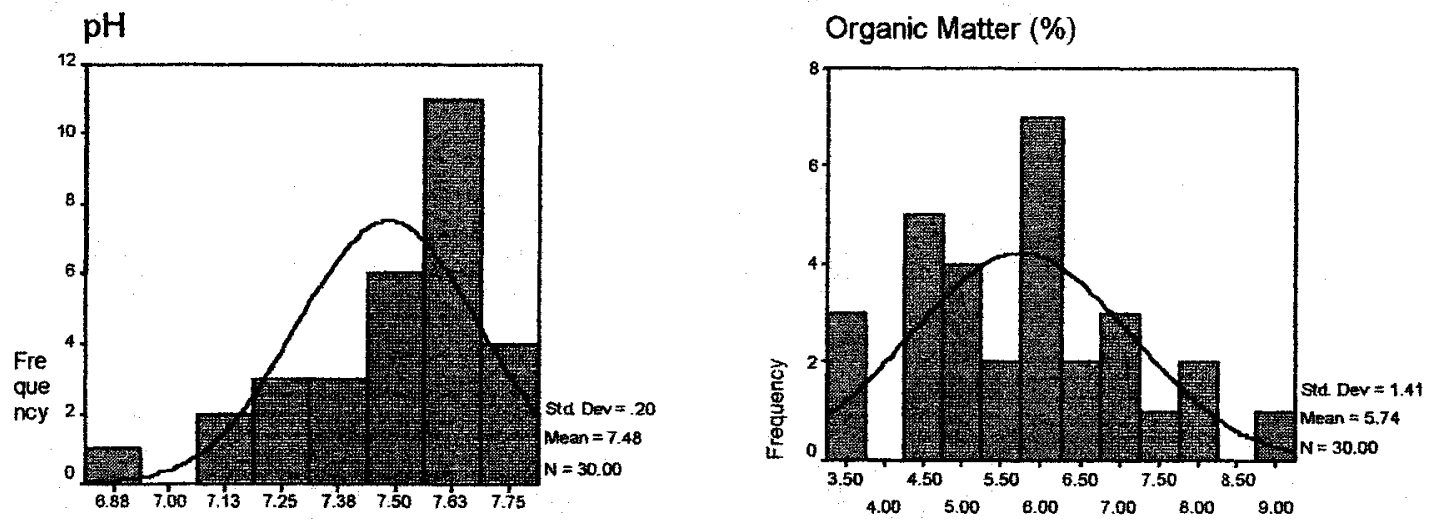

$\mathrm{PH}$

Organic Matter (\%) 


\section{Appendix A: Distribution of Measured Variables (Continued)}

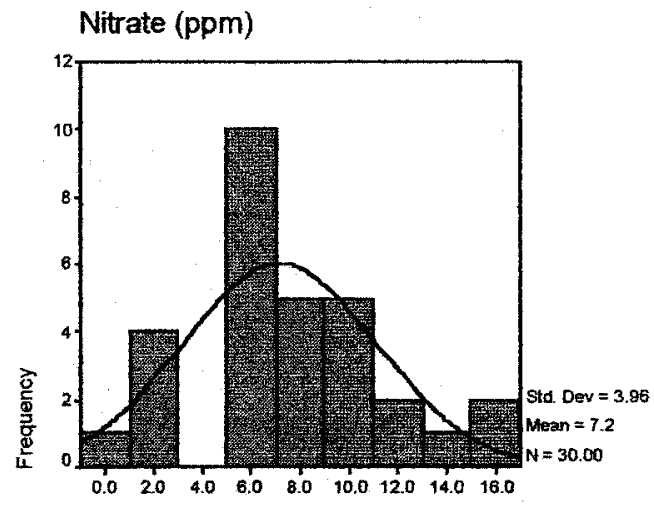

Nitrate (ppm)

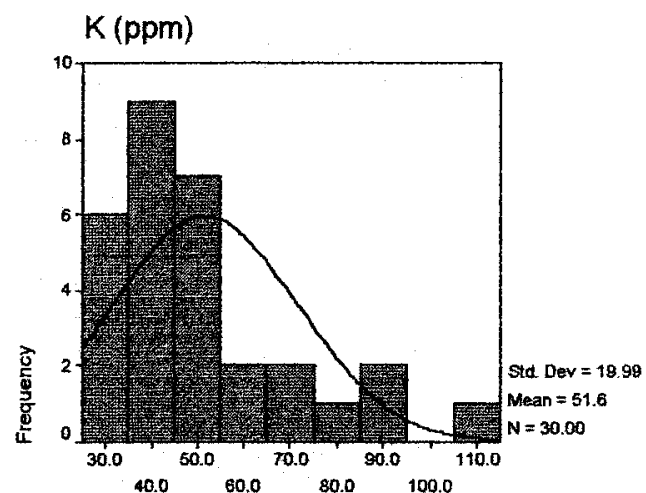

$\mathrm{K}$ (ppm)

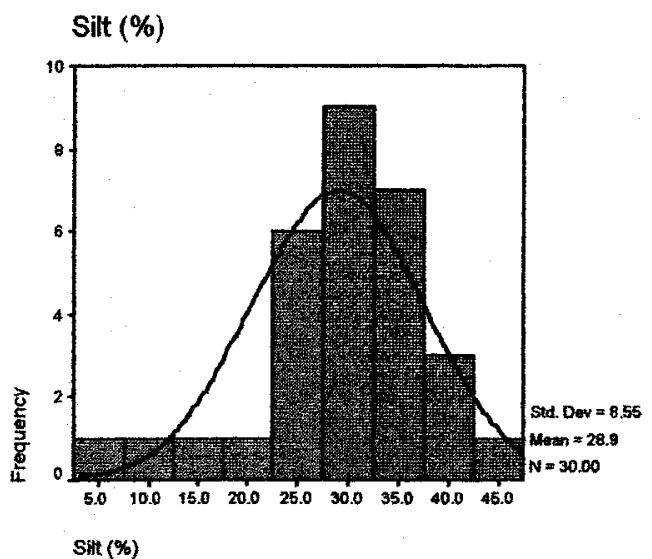

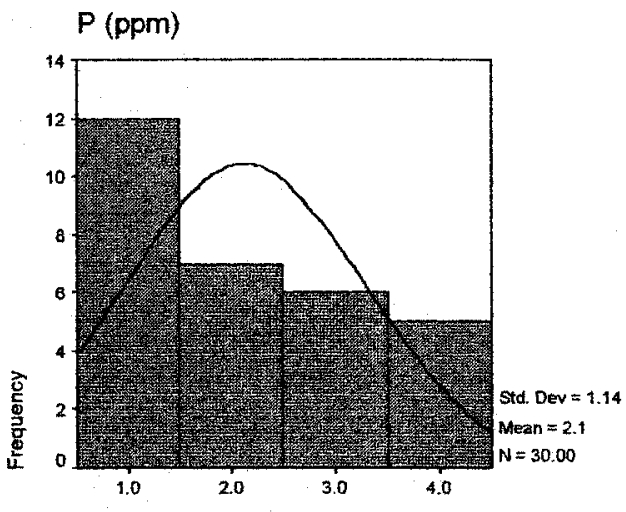

$P$ (ppm)

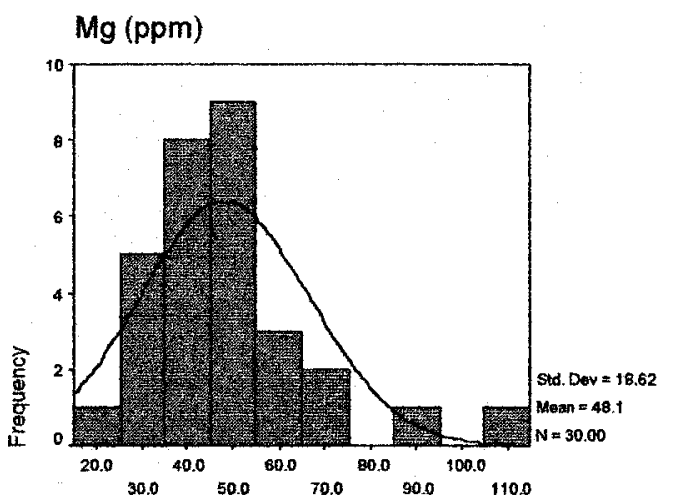

$\mathrm{Mg}(\mathrm{ppm})$

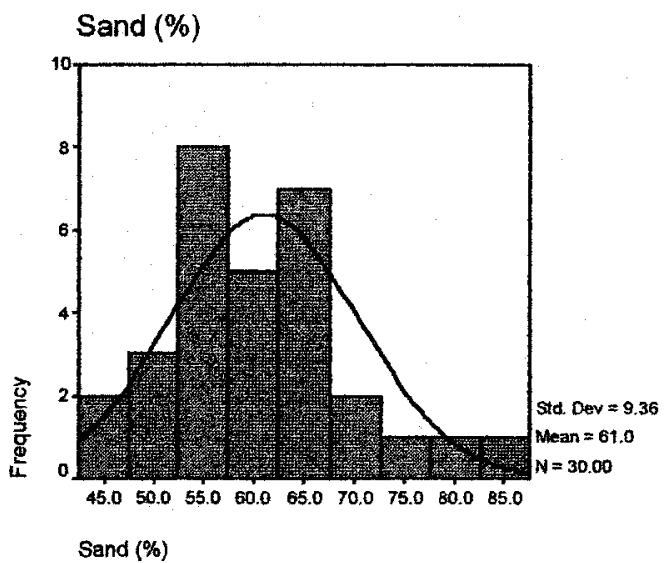


Appendix A: Distribution of Measured Variables (Continued)

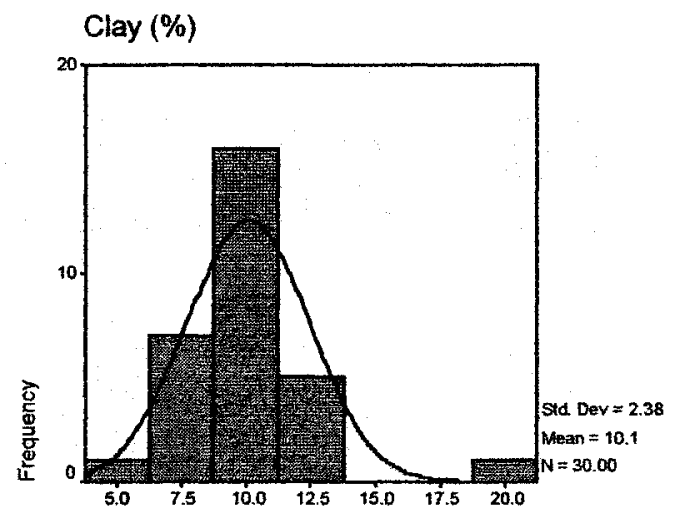

Clay $(\%)$ 
Appendix B: Per cent Crown Closure of Euphorbia cyparissias, 2004

\begin{tabular}{|c|c|c|c|c|c|}
\hline Protio & 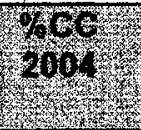 & Cover & Prot us & roof & copertass \\
\hline A33 & 0 & 1 & DO & 25 & 2 \\
\hline A37 & 0 & 1 & D4 & 5 & 2 \\
\hline A43 & 0 & 1 & D8 & 5 & 2 \\
\hline A49 & 0 & 1 & D10 & 0 & 1 \\
\hline A60 & 5 & 2 & D50 & 5 & 2 \\
\hline A61 & 0 & 1 & D84 & 5 & 2 \\
\hline $\mathrm{A} 62$ & 5 & $\overline{2}$ & D85 & 5 & 2 \\
\hline A70 & 10 & 2 & D86 & 5 & 2 \\
\hline$\overline{A 89}$ & 0 & 1 & D95 & 5 & 2 \\
\hline A97 & 0 & 1 & D96 & 5 & 2 \\
\hline B22 & 5 & 2 & $E 22$ & 0 & 1 \\
\hline B23 & 5 & 2 & E23 & 0 & 1 \\
\hline B38 & 5 & 2 & E34 & 0 & 1 \\
\hline B41 & 5 & 2 & E55 & 5 & 2 \\
\hline B58 & 10 & 2 & $E 56$ & 0 & 1 \\
\hline $\bar{B} 60$ & 20 & 2 & E63 & 5 & 2 \\
\hline$\overline{B 61}$ & 5 & 2 & E71 & 5 & 2 \\
\hline B78 & 5 & 2 & E78 & 0 & 1 \\
\hline B89 & 0 & 1 & E81 & 5 & 2 \\
\hline B93 & 5 & 2 & E98 & 5 & 2 \\
\hline $\mathrm{CO}$ & 30 & 3 & F7 & 0 & 1 \\
\hline $\mathrm{C}_{10}$ & 0 & 1 & $F 16$ & 0 & 1 \\
\hline$\overline{C 11}$ & 5 & 2 & $\mathrm{~F} 20$ & 0 & 1 \\
\hline C14 & 5 & 2 & F36 & 0 & 1 \\
\hline$\overline{C 25}$ & 10 & 2 & F56 & 0 & 1 \\
\hline $\mathrm{C} 30$ & 5 & 2 & F64 & 0 & 1 \\
\hline$\overline{C 35}$ & 5 & 2 & F76 & 0 & 1 \\
\hline$\overline{C 51}$ & 0 & 1 & F79 & 0 & 1 \\
\hline C67 & 0 & 1 & F81 & 0 & 1 \\
\hline $\mathrm{C88}$ & 0 & 1 & F97 & 0 & 1 \\
\hline
\end{tabular}




\section{Appendix C: Soil Seed Bank Study Results}

\begin{tabular}{|c|c|c|c|c|}
\hline Row & Plot & Date & Species & Quantity \\
\hline A & 30 & 2010104 & Worenimu pertoraum & 10 \\
\hline A & 33 & 06-Dec-03 & Hypericum perforatum & 1 \\
\hline $\mathrm{A}$ & 33 & 11-Dec-03 & Poa compressa & 7 \\
\hline $\bar{A}$ & 33 & 11-Dec-03 & Verbascum thapsus & 1 \\
\hline A & 33 & 27-Dec-03 & Hypericum perforatum & 2 \\
\hline$A$ & 33 & 10-Jan-04 & Hypericum perforatum & 2 \\
\hline A & 33 & 10-Jan-04 & Chaenorrhinum minus & 1 \\
\hline $\bar{A}$ & 33 & 10-Jan-04 & Stachys palustris & 1 \\
\hline A & 33 & 10-Jan-04 & Rumex acetosella & 1 \\
\hline $\bar{A}$ & 33 & 24-Jan-04 & Hypericum perforatum & 2 \\
\hline $\bar{A}$ & 33 & 08-Feb-04 & Oxalis stricta & 1 \\
\hline $\bar{A}$ & 33 & 27-Feb-04 & Poa compressa & 2 \\
\hline $\bar{A}$ & 33 & 27-Feb-04 & Hypericum perforatum & 3 \\
\hline A & 37 & 20.101003 & 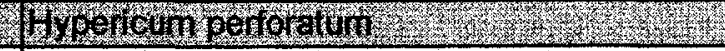 & 9 \\
\hline A & 37 & $30-N o v-03$ & Hypericum perforatum & 2 \\
\hline A & 37 & 06-Dec-03 & Verbascum thapsus & 1 \\
\hline A & 37 & 11-Dec-03 & Echium vulgare & 1 \\
\hline A & 37 & 20-Dec-03 & Fragaria virginiana & 1 \\
\hline $\bar{A}$ & 37 & 10-Jan-04 & Stachys palustris & 1 \\
\hline A & 37 & 10-Jan-04 & Oenothera biennis & 1 \\
\hline A & 37 & 10-Jan-04 & Poa compressa & 4 \\
\hline A & 37 & 10-Jan-04 & Hypericum perforatum & 2 \\
\hline A & 37 & 18-Jan-04 & Oxalis stricta & 1 \\
\hline $\bar{A}$ & 37 & 21-Jan-04 & Hypericum perforatum & 2 \\
\hline A & 37 & 24-Jan-04 & Poa compressa & 2 \\
\hline A & 37 & 24-Jan-04 & Oxalis stricta & 1 \\
\hline$A$ & 37 & 24-Jan-04 & Hypericum perforatum & 1 \\
\hline A & 37 & 08-Feb-04 & Oxalis stricta & 1 \\
\hline A & 37 & 27-Feb-04 & Hypericum perforatum & 4 \\
\hline$A$ & 37 & 27-Feb-04 & Oxalis stricta & 1 \\
\hline 烈 & 16 & 2010003 & 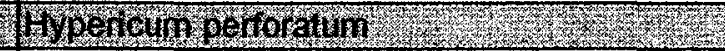 & 9 \\
\hline A & 43 & 20-Nov-03 & Melilotus alba & 1 \\
\hline$A$ & 43 & 06-Dec-03 & Verbascum thapsus & 2 \\
\hline$A$ & 43 & 06-Dec-03 & Hypericum perforatum & 2 \\
\hline $\mathrm{A}$ & 43 & 11-Dec-03 & Poa compressa & 9 \\
\hline $\bar{A}$ & 43 & 11-Dec-03 & Hypericum perforatum & 1 \\
\hline$A$ & 43 & 20-Dec-03 & Fragaria virginiana & 4 \\
\hline $\mathrm{A}$ & 43 & 27-Dec-03 & Senecio pauperculus & 1 \\
\hline $\mathrm{A}$ & 43 & 27-Dec-03 & Solidago nemoralis & 4 \\
\hline $\bar{A}$ & 43 & 10-Jan-04 & Verbascum thapsus & 1 \\
\hline A & 43 & 18-Jan-04 & Fragaria virginiana & 5 \\
\hline $\bar{A}$ & 43 & 18-Jan-04 & Hypericum perforatum & 1 \\
\hline$A$ & 43 & 21-Jan-04 & Hypericum perforatum & 2 \\
\hline
\end{tabular}


85

\begin{tabular}{|c|c|c|c|c|}
\hline \multicolumn{5}{|c|}{ Appendix C: Soil Seed Bank Study Results Continued } \\
\hline Row & Plot & Date & Species & Quantity \\
\hline A & 43 & 21-Jan-04 & Fragaria virginiana & 1 \\
\hline A & 43 & 24-Jan-04 & Poa compressa & 1 \\
\hline A & 43 & 24-Jan-04 & Hypericum perforatum & 1 \\
\hline$A$ & 43 & $01-F e b-04$ & Hypericum perforatum & 2 \\
\hline$A$ & 43 & $01-$ Feb-04 & Poa compressa & 2 \\
\hline$A$ & 43 & 27-Feb-04 & Fragaria virginiana & 2 \\
\hline A & 43 & 27-Feb-04 & Poa compressa & 2 \\
\hline$A$ & 49 & $30.110 v 03$ & Hyonglmoeroforing & 2 \\
\hline A & 49 & 10-Jan-04 & Poa compressa & 2 \\
\hline A & 49 & 01-Feb-04 & Hypericum perforatum & 2 \\
\hline A & 49 & 27-Feb-04 & Hypericum perforatum & 1 \\
\hline A & 60 & 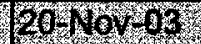 & 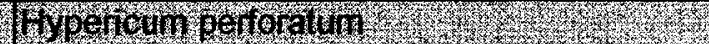 & dit? \\
\hline A & 60 & 11-Dec-03 & Poa compressa & 2 \\
\hline $\bar{A}$ & 60 & 20-Dec-03 & Fragaria virginiana & 1 \\
\hline$A$ & 60 & 27-Dec-03 & Hypericum perforatum & 1 \\
\hline A & 60 & $27-$ Dec-03 & Campanula rotundifolia & 1 \\
\hline A & 60 & 27-Dec-03 & Solidago nemoralis & 1 \\
\hline$A$ & 60 & 27-Dec-03 & Senecio pauperculus & 1 \\
\hline $\mathrm{A}$ & 60 & 18-Jan-04 & Hypericum perforatum & 1 \\
\hline A & 60 & 24-Jan-04 & Poa compressa & 1 \\
\hline A & 60 & 27-Feb-04 & Hypericum perforatum & 1 \\
\hline A & 60 & 27-Feb-04 & Solidago nemoralis & 1 \\
\hline A & 612 & $20100 \times 03$ & 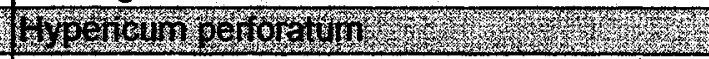 & 8 8) \\
\hline $\mathrm{A}$ & 61 & 20-Nov-03 & Leucanthemum vulgare & 1 \\
\hline $\bar{A}$ & 61 & 30-Nov-03 & Hypericum perforatum & 1 \\
\hline A & 61 & 20-Dec-03 & Fragaria virginiana & 1 \\
\hline A & 61 & 10-Jan-04 & Solidago nemoralis & 2 \\
\hline A & 61 & 10-Jan-04 & Oxalis stricta & 1 \\
\hline$A$ & 61 & 18-Jan-04 & Fragaria virginiana & 1 \\
\hline A & 61 & 18-Jan-04 & Hypericum perforatum & 1 \\
\hline A & 61 & 18-Jan-04 & Oxalis stricta & 1 \\
\hline A & 61 & $01-F e b-04$ & Hypericum perforatum & 3 \\
\hline $\mathrm{A}$ & 61 & $01-F e b-04$ & Oxalis stricta & 2 \\
\hline $\mathrm{A}$ & 61 & $08-F e b-04$ & Poa compressa & 1 \\
\hline$A$ & 61 & 27-Feb-04 & Panicum linearifolium & 1 \\
\hline $\mathrm{A}$ & 61 & 27-Feb-04 & Fragaria virginiana & 1 \\
\hline $\bar{A}$ & 61 & 27-Feb-04 & Hypericum perforatum & 1 \\
\hline X & 62 & $20.10 v 09$ & 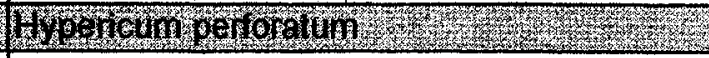 & 13 \\
\hline $\mathrm{A}$ & 62 & 30-Nov-03 & Hypericum perforatum & 3 \\
\hline $\mathrm{A}$ & 62 & 06-Dec-03 & Hypericum perforatum & 1 \\
\hline $\bar{A}$ & 62 & 11-Dec-03 & Echium vulgare & 1 \\
\hline$A$ & 62 & 18-Jan-04 & Fragaria virginiana & 1 \\
\hline$A$ & 62 & 24-Jan-04 & Echium vulgare & 1 \\
\hline A & 62 & 08-Feb-04 & Melilotus alba & 1 \\
\hline
\end{tabular}




\begin{tabular}{|c|c|c|c|c|}
\hline \multicolumn{5}{|c|}{ Appendix C: Soil Seed Bank Study Results Continued } \\
\hline Row & Plot & Date & Species & Quantity \\
\hline A & 62 & $08-F e b-04$ & Oxalis stricta & 1 \\
\hline A & 62 & $08-F e b-04$ & Senecio pauperculus & 1 \\
\hline A & 70 & $20110 \times 103$ & 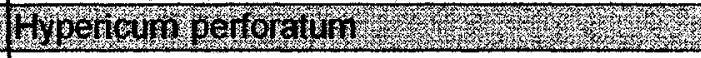 & 7 \\
\hline A & 70 & $30-$ Nov-03 & Hypericum perforatum & 3 \\
\hline A & 70 & $11-$ Dec-03 & Chaenorrhinum minus & 1 \\
\hline A & 70 & 20-Dec-03 & Fragaria virginiana & 1 \\
\hline $\bar{A}$ & 70 & $27-$ Dec-03 & Hypericum perforatum & 1 \\
\hline A & 70 & 27-Dec-03 & Solidago nemoralis & 3 \\
\hline A & 70 & 24-Jan-04 & Minuartia michauxii & 1 \\
\hline$A$ & 70 & $01-$ Feb-04 & Oxalis stricta & 1 \\
\hline $\bar{A}$ & 70 & $01-F e b-04$ & Campanula rotundifolia & 1 \\
\hline $\bar{A}$ & 70 & $01-F e b-04$ & Hypericum perforatum & 2 \\
\hline $\bar{A}$ & 70 & 27-Feb-04 & Solidago nemoralis & 1 \\
\hline A & 70 & $27-F e b-04$ & Poa compressa & 1 \\
\hline$A$ & 70 & $27-$ Feb-04 & Hypericum perforatum & 7 \\
\hline A & 89 & 204 Nov 08 & Oxals shicta & 3 \\
\hline $\mathrm{A}$ & 89 & $20-N o v-03$ & Hypericum perforatum & 12 \\
\hline $\bar{A}$ & 89 & 06-Dec-03 & Hypericum perforatum & 4 \\
\hline $\bar{A}$ & 89 & 11-Dec-03 & Poa compressa & 9 \\
\hline$A$ & 89 & 11-Dec-03 & Chaenorrhinum minus & 1 \\
\hline A & 89 & 11-Dec-03 & Verbascum thapsus & 2 \\
\hline $\bar{A}$ & 89 & 20-Dec-03 & Hypericum perforatum & 1 \\
\hline $\bar{A}$ & 89 & 27-Dec-03 & Minuartia michauxii & 1 \\
\hline $\bar{A}$ & 89 & 27-Dec-03 & Hypericum perforatum & 1 \\
\hline$A$ & 89 & 10-Jan-04 & Solidago nemoralis & 1 \\
\hline $\bar{A}$ & 89 & 10-Jan-04 & Senecio pauperculus & 1 \\
\hline$A$ & 89 & 18-Jan-04 & Hypericum perforatum & 1 \\
\hline $\bar{A}$ & 89 & 21-Jan-04 & Oxalis stricta & 1 \\
\hline $\bar{A}$ & 89 & 24-Jan-04 & Hypericum perforatum & 2 \\
\hline A & 89 & 27-Feb-04 & Hypericum perforatum & 2 \\
\hline A & 89 & 27-Feb-04 & Minuartia michauxii & 1 \\
\hline (t) & 97 & $20 \times 1000$ & 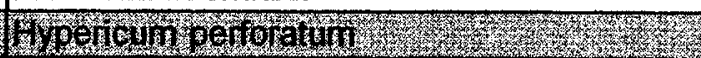 & 24 \\
\hline A & 97 & 20-Nov-03 & Melilotus alba & 1 \\
\hline$A$ & 97 & 06-Dec-03 & Hypericum perforatum & 1 \\
\hline A & 97 & 06-Dec-03 & Oxalis stricta & 1 \\
\hline A & 97 & 11-Dec-03 & Verbascum thapsus & 1 \\
\hline A & 97 & 20-Dec-03 & Fragaria virginiana & 1 \\
\hline $\bar{A}$ & 97 & 27-Dec-03 & Hypericum perforatum & 2 \\
\hline A & 97 & 27-Dec-03 & Echium vulgare & 2 \\
\hline $\bar{A}$ & 97 & $10-\operatorname{Jan}-04$ & Poa compressa & 2 \\
\hline$A$ & 97 & 18-Jan-04 & Hypericum perforatum & 1 \\
\hline A & 97 & 21-Jan-04 & Hypericum perforatum & 4 \\
\hline A & 97 & 24-Jan-04 & Poa compressa & 2 \\
\hline $\mathrm{A}$ & 97 & 24-Jan-04 & Echium vulgare & 1 \\
\hline
\end{tabular}




\begin{tabular}{|c|c|c|c|c|}
\hline \multicolumn{5}{|c|}{ Appendix C: Soil Seed Bank Study Results Continued } \\
\hline Row & Plot & Date & Species & Quantity \\
\hline $\bar{A}$ & 97 & 24-Jan-04 & Hypericum perforatum & 2 \\
\hline $\bar{A}$ & 97 & 08-Feb-04 & Hypericum perforatum & 1 \\
\hline B: & 22 & $20400 \%$ & Hypo- Reun perforatin & 9 \\
\hline $\mathrm{B}$ & 22 & 20-Dec-03 & Fragaria virginiana & 1 \\
\hline B & 22 & 27-Dec-03 & Campanula rotundifolia & 1 \\
\hline $\mathbf{B}$ & 22 & 27-Dec-03 & Senecio pauperculus & 2 \\
\hline $\bar{B}$ & 22 & 27-Dec-03 & Echium vulgare & 1 \\
\hline $\mathbf{B}$ & 22 & 10-Jan-04 & Senecio pauperculus & 1 \\
\hline B & 22 & 10-Jan-04 & Poa compressa & 1 \\
\hline $\mathbf{B}$ & 22 & 24-Jan-04 & Poa compressa & 1 \\
\hline $\bar{B}$ & 22 & 01-Feb-04 & Oxalis stricta & 1 \\
\hline B & 22 & 08-Feb-04 & Hypericum perforatum & 1 \\
\hline B. & 28 & 20. Noveg & Nellotus o oro & $4 x_{1}$ \\
\hline B & 23 & $20-$ Nov- 03 & Hypericum perforatum & 19 \\
\hline B & 23 & $20-$ Nov-03 & Leucanthemum vulgare & 4 \\
\hline B & 23 & 20-Nov-03 & Verbascum thapsus & 1 \\
\hline $\mathbf{B}$ & 23 & 30-Nov-03 & Echium vulgare & $\overline{1}$ \\
\hline B & 23 & 06-Dec-03 & Oxalis stricta & 1 \\
\hline $\mathbf{B}$ & 23 & 11-Dec-03 & Poa compressa & 3 \\
\hline B & 23 & 20-Dec-03 & Fragaria virginiana & 1 \\
\hline B & 23 & 20-Dec-03 & Campanula rotundifolia & 1 \\
\hline B & 23 & 27-Dec-03 & Campanula rotundifolia & 3 \\
\hline$B$ & 23 & 27-Dec-03 & Senecio pauperculus & 1 \\
\hline B & 23 & 10-Jan-04 & Echium vulgare & 1 \\
\hline $\bar{B}$ & 23 & 10-Jan-04 & Hypericum perforatum & 1 \\
\hline $\bar{B}$ & 23 & $10-J a n-04$ & Viola adunca & 1 \\
\hline B & 23 & 21-Jan-04 & Oxalis stricta & 1 \\
\hline B & 23 & 24-Jan-04 & Danthonia spicata & 1 \\
\hline B & 23 & 24-Jan-04 & Oxalis stricta & 1 \\
\hline B & 23 & 01-Feb-04 & Solidago nemoralis & 2 \\
\hline B & 38 & $20 \mathrm{Nov}=03$ & Weroascum hapsis & (1) \\
\hline B & 38 & 20-Nov-03 & Hypericum perforatum & 8 \\
\hline$B$ & 38 & 06-Dec-03 & Echium vulgare & 1 \\
\hline$B$ & 38 & 11-Dec-03 & Poa compressa & 3 \\
\hline $\mathrm{B}$ & 38 & 27-Dec-03 & Scutellaria parvula & 1 \\
\hline$B$ & 38 & 18-Jan-04 & Hypericum perforatum & 1 \\
\hline $\mathbf{B}$ & 38 & 21-Jan-04 & Hypericum perforatum & $\overline{1}$ \\
\hline$B$ & 38 & 01-Feb-04 & Hypericum perforatum & 1 \\
\hline $\bar{B}$ & 38 & 27-Feb-04 & Hypericum perforatum & 2 \\
\hline 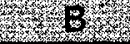 & 41. & 20110703 & HYpencum reromero & 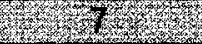 \\
\hline B & 41 & 06-Dec-03 & Panicum linearifolium & 1 \\
\hline$B$ & 41 & 11-Dec-03 & Hypericum perforatum & 2 \\
\hline$B$ & 41 & 14-Jan-04 & Hypericum perforatum & 4 \\
\hline $\mathrm{B}$ & 41 & 14-Jan-04 & Verbascum thapsus & 1 \\
\hline B & 41 & 24-Jan-04 & Campanula rotundifolia & 1 \\
\hline
\end{tabular}




\begin{tabular}{|c|c|c|c|c|}
\hline \multicolumn{5}{|c|}{ Appendix C: Soil Seed Bank Study Results Continued } \\
\hline Row & Plot & Date & Species & Quantity \\
\hline B & 41 & 24-Jan-04 & Senecio pauperculus & 2 \\
\hline B & 41 & $08-\mathrm{Feb}-04$ & Campanula rotundifolia & 1 \\
\hline B. & 58 & 201000.08 & 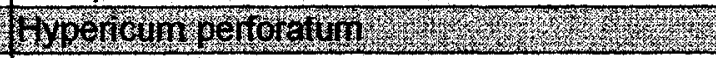 & 8 \\
\hline B & 58 & 06-Dec-03 & Verbascum thapsus & 2 \\
\hline B & 58 & 11-Dec-03 & Poa compressa & 7 \\
\hline B & 58 & 27-Dec-03 & Campanula rotundifolia & 3 \\
\hline $\bar{B}$ & 58 & 27-Dec-03 & Senecio pauperculus & 2 \\
\hline $\bar{B}$ & 58 & 27-Dec-03 & Fragaria virginiana & 1 \\
\hline B & 58 & 10-Jan-04 & Daphnia spicata & 1 \\
\hline B & 58 & 10-Jan-04 & Deschampsia flexuosa & 1 \\
\hline B & 58 & 14-Jan-04 & Leucanthemum vulgare & 1 \\
\hline $\bar{B}$ & 58 & 24-Jan-04 & Oxalis stricta & 1 \\
\hline $\bar{B}$ & 58 & 24-Jan-04 & Hypericum perforatum & 2 \\
\hline$B$ & 58 & $01-F e b-04$ & Oxalis stricta & 1 \\
\hline 8 & 60 & $20 \times 10 \times 103$ & 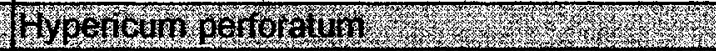 & 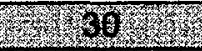 \\
\hline$B$ & 60 & 20-Nov-03 & Leucanthemum vulgare & 5 \\
\hline B & 60 & $30-$ Nov-03 & Verbascum thapsus & 1 \\
\hline B & 60 & 06-Dec-03 & Verbascum thapsus & 1 \\
\hline $\bar{B}$ & 60 & 06-Dec-03 & Euphorbia cyparissias & 1 \\
\hline B & 60 & 11-Dec-03 & Poa compressa & 16 \\
\hline B & 60 & 11-Dec-03 & Chaenorrhinum minus & 1 \\
\hline B & 60 & 20-Dec-03 & Fragaria virginiana & 4 \\
\hline B & 60 & 27-Dec-03 & Campanula rotundifolia & 3 \\
\hline $\bar{B}$ & 60 & 27-Dec-03 & Senecio pauperculus & 2 \\
\hline $\mathrm{B}$ & 60 & 27-Dec-03 & Solidago nemoralis & 5 \\
\hline $\bar{B}$ & 60 & 27-Dec-03 & Hypericum perforatum & 3 \\
\hline B & 60 & 10-Jan-04 & Verbascum thapsus & 1 \\
\hline B & 60 & 10-Jan-04 & Poa compressa & 2 \\
\hline B & 60 & 14-Jan-04 & Hypericum perforatum & 6 \\
\hline $\bar{B}$ & 60 & 18-Jan-04 & Verbascum thapsus & 1 \\
\hline $\mathrm{B}$ & 60 & 24-Jan-04 & Poa compressa & 2 \\
\hline$B$ & 60 & 24-Jan-04 & Oxalis stricta & 1 \\
\hline$B$ & 60 & 24-Jan-04 & Leucanthemum vulgare & 1 \\
\hline B & 60 & $01-\mathrm{Feb}-04$ & Oxalis stricta & 1 \\
\hline$B$ & 60 & 08-Feb-04 & Senecio pauperculus & 1 \\
\hline B & 60 & 08-Feb-04 & Hypericum perforatum & 1 \\
\hline $\bar{B}$ & 60 & 27-Feb-04 & Hypericum perforatum & 4 \\
\hline$B$ & 60 & 27-Feb-04 & Senecio pauperculus & 3 \\
\hline 8 & 6 & 20. & Mellotus alla & 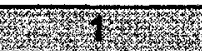 \\
\hline B & 61 & $20-\mathrm{Nov}-03$ & Hypericum perforatum & 23 \\
\hline $\bar{B}$ & 61 & 20-Nov-03 & Leucanthemum vulgare & 5 \\
\hline$B$ & 61 & $30-$ Nov-03 & Verbascum thapsus & 2 \\
\hline B & 61 & 06-Dec-03 & Verbascum thapsus & 2 \\
\hline B & 61 & 06-Dec-03 & Hypericum perforatum & 1 \\
\hline B & 61 & 06-Dec-03 & Panicum linearifolium & 1 \\
\hline
\end{tabular}


89

\begin{tabular}{|c|c|c|c|c|}
\hline \multicolumn{5}{|c|}{ Appendix C: Soil Seed Bank Study Results Continued } \\
\hline Row & Plot & Date & Species & Quantity \\
\hline B & 61 & 11-Dec-03 & Poa compressa & 2 \\
\hline B & 61 & 11-Dec-03 & Chaenorrhinum minus & 1 \\
\hline $\bar{B}$ & 61 & 20-Dec-03 & Fragaria virginiana & 2 \\
\hline $\mathrm{B}$ & 61 & 20-Dec-03 & Hieracium piloselloides & 1 \\
\hline B & 61 & 27-Dec-03 & Campanula rotundifolia & 3 \\
\hline B & 61 & 27-Dec-03 & Senecio pauperculus & 3 \\
\hline B & 61 & $10-$ Jan-04 & Oenothera biennis & 1 \\
\hline $\bar{B}$ & 61 & 10-Jan-04 & Hypericum perforatum & 4 \\
\hline $\mathbf{B}$ & 61 & 10-Jan-04 & Leucanthemum vulgare & 1 \\
\hline B & 61 & 18-Jan-04 & Hypericum perforatum & 1 \\
\hline B & 61 & 24-Jan-04 & Campanula rotundifolia & 1 \\
\hline B & 61 & $01-F e b-04$ & Hypericum perforatum & 1 \\
\hline B & 61 & 27-Feb-04 & Senecio pauperculus & 2 \\
\hline $\bar{B}$ & 61 & $27-F e b-04$ & Hypericum perforatum & 6 \\
\hline $\mathbf{B}$ & 61 & $27-F e b-04$ & Acer spp. & 1 \\
\hline B. & 78 & 20.100603 & Woricun oeroratum & (2) \\
\hline B & 78 & $20-$ Nov-03 & Daucus carota & 1 \\
\hline B & 78 & 30-Nov-03 & Hypericum perforatum & 2 \\
\hline$B$ & 78 & 06-Dec-03 & Verbascum thapsus & 1 \\
\hline$B$ & 78 & 06-Dec-03 & Panicum linearifolium & 3 \\
\hline B & 78 & 11-Dec-03 & Hypericum perforatum & 3 \\
\hline B & 78 & 11-Dec-03 & Poa compressa & 8 \\
\hline B & 78 & 20-Dec-03 & Hypericum perforatum & 1 \\
\hline B & 78 & 27-Dec-03 & Campanula rotundifolia & 3 \\
\hline B & 78 & 10-Jan-04 & Hypericum perforatum & 5 \\
\hline $\bar{B}$ & 78 & 14-Jan-04 & Verbascum thapsus & 1 \\
\hline$B$ & 78 & 18-Jan-04 & Fragaria virginiana & 1 \\
\hline$B$ & 78 & 24-Jan-04 & Poa compressa & 1 \\
\hline$B$ & 78 & 24-Jan-04 & Hypericum perforatum & 3 \\
\hline B & 78 & 24-Jan-04 & Campanula rotundifolia & 1 \\
\hline B. & 899 & $20110 y-03$ & Hypencum perforalum & 5 \\
\hline B & 89 & $30-N o v-03$ & Leucanthemum vulgare & 1 \\
\hline$B$ & 89 & $30-$ Nov-03 & Hypericum perforatum & 1 \\
\hline$B$ & 89 & 06-Dec-03 & Panicum linearifolium & 5 \\
\hline$B$ & 89 & 11-Dec-03 & Senecio pauperculus & 1 \\
\hline $\bar{B}$ & 89 & 20-Dec-03 & Hypericum perforatum & 4 \\
\hline $\bar{B}$ & 89 & 20-Dec-03 & Oxalis stricta & 1 \\
\hline $\mathrm{B}$ & 89 & 27-Dec-03 & Senecio pauperculus & 2 \\
\hline B & 89 & 10-Jan-04 & Verbascum thapsus & 2 \\
\hline $\bar{B}$ & 89 & 10-Jan-04 & Senecio pauperculus & 1 \\
\hline B & 89 & 10-Jan-04 & Danthonia spicata & 1 \\
\hline B & 89 & 10-Jan-04 & Verbascum thapsus & 1 \\
\hline $\bar{B}$ & 89 & 10-Jan-04 & Poa compressa & 1 \\
\hline B & 89 & 10-Jan-04 & Hypericum perforatum & 3 \\
\hline$B$ & 89 & 24-Jan-04 & Hypericum perforatum & 2 \\
\hline
\end{tabular}


90

\begin{tabular}{|c|c|c|c|c|}
\hline \multicolumn{5}{|c|}{ Appendix C: Soil Seed Bank Study Results Continued } \\
\hline Row & Plot & Date & Species & Quantity \\
\hline$\overline{\mathrm{B}}$ & 89 & $01-$ Feb-04 & Poa compressa & 1 \\
\hline B. & 98 & 20. Now 03 & 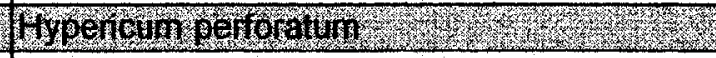 & (2) \\
\hline B & 93 & $30-$ Nov-03 & Hieracium piloselloides & 1 \\
\hline B & 93 & $30-$ Nov-03 & Hypericum perforatum & 1 \\
\hline B & 93 & 11-Dec-03 & Verbascum thapsus & 2 \\
\hline B & 93 & 27-Dec-03 & Campanula rotundifolia & 1 \\
\hline B & 93 & 10-Jan-04 & Hypericum perforatum & 3 \\
\hline$\overline{\mathrm{B}}$ & 93 & 10-Jan-04 & Deschampsia flexuosa & 1 \\
\hline $\mathrm{B}$ & 93 & 14-Jan-04 & Hypericum perforatum & 1 \\
\hline B & $\overline{93}$ & 24-Jan-04 & Poa compressa & 2 \\
\hline B & 93 & 24-Jan-04 & Campanula rotundifolia & 1 \\
\hline $\bar{B}$ & 93 & 24-Jan-04 & Hypericum perforatum & 1 \\
\hline c. & 0 & 20 Novo3 & 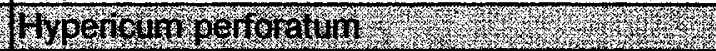 & 2 \\
\hline C & 0 & $20-$ Nov-03 & Melilotus alba & 4 \\
\hline $\mathrm{C}$ & 0 & 11-Dec-03 & Senecio pauperculus & 1 \\
\hline C & 0 & 11-Dec-03 & Chaenorrhinum minus & 1 \\
\hline C & 0 & 20-Dec-03 & Panicum linearifolium & 1 \\
\hline C & 0 & 10-Jan-04 & Poa compressa & 3 \\
\hline C & 0 & 18-Jan-04 & Oxalis stricta & 1 \\
\hline $\mathrm{C}$ & 0 & 24-Jan-04 & Panicum linearifolium & 1 \\
\hline C & 0 & $01-F e b-04$ & Senecio pauperculus & 1 \\
\hline C & 0 & 01-Feb-04 & Poa compressa & 1 \\
\hline C. & 10 & 20110103 & 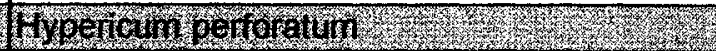 & S. \\
\hline C & 10 & 06-Dec-03 & Verbascum thapsus & 1 \\
\hline $\mathrm{C}$ & 10 & 06-Dec-03 & Oxalis stricta & 1 \\
\hline $\mathrm{C}$ & 10 & 11-Dec-03 & Senecio pauperculus & 1 \\
\hline $\mathrm{C}$ & 10 & 11-Dec-03 & Poa compressa & 2 \\
\hline $\mathrm{C}$ & 10 & 27-Dec-03 & Senecio pauperculus & 2 \\
\hline $\mathrm{C}$ & 10 & 10-Jan-04 & Solidago nemoralis & 1 \\
\hline $\mathrm{C}$ & 10 & 10-Jan-04 & Hypericum perforatum & 1 \\
\hline $\mathrm{C}$ & 10 & 10-Jan-04 & Deschampsia flexuosa & 1 \\
\hline $\mathrm{C}$ & 10 & 18-Jan-04 & Oxalis stricta & 1 \\
\hline C & 10 & 18-Jan-04 & Fragaria virginiana & 1 \\
\hline $\mathrm{C}$ & 10 & 24-Jan-04 & Poa compressa & 1 \\
\hline $\mathrm{C}$ & 10 & $01-F e b-04$ & Hypericum perforatum & 1 \\
\hline $\mathrm{C}$ & 10 & 08-Feb-04 & Daucus carota & 1 \\
\hline $\mathrm{C}$ & 10 & 27-Feb-04 & Hypericum perforatum & 3 \\
\hline $\mathrm{C}$ & 10 & 27-Feb-04 & Echium vulgare & 1 \\
\hline $\mathrm{e}$ & Th & 20 Nov.68 & 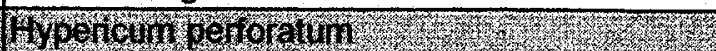 & 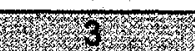 \\
\hline C & 11 & 20-Nov-03 & Daucus carota & 2 \\
\hline $\mathrm{C}$ & 11 & 06-Dec-03 & Euphorbia cyparissias & 1 \\
\hline $\mathrm{C}$ & 11 & 06-Dec-03 & Panicum linearifolium & 1 \\
\hline $\mathrm{C}$ & 11 & 20-Dec-03 & Fragaria virginiana & 4 \\
\hline C & 11 & 26-Dec-03 & Fragaria virginiana & 1 \\
\hline C & 11 & 26-Dec-03 & Echium vulgare & 1 \\
\hline
\end{tabular}


91

\begin{tabular}{|c|c|c|c|c|}
\hline \multicolumn{5}{|c|}{ Appendix C: Soil Seed Bank Study Results Continued } \\
\hline Row & Plot & Date & Species & Quantity \\
\hline C & 11 & 27-Dec-03 & Senecio pauperculus & 1 \\
\hline C & 11 & $10-\operatorname{Jan}-04$ & Senecio pauperculus & 1 \\
\hline C & 11 & 10-Jan-04 & Hypericum perforatum & 2 \\
\hline C & 11 & $10-J a n-04$ & Poa compressa & 2 \\
\hline C & 11 & 14-Jan-04 & Fragaria virginiana & 1 \\
\hline C & 11 & 08-Feb-04 & Oxalis stricta & 1 \\
\hline C & 11 & $27-F e b-04$ & Fragaria virginiana & 5 \\
\hline C. & ry & $11-\operatorname{dec} 03$ & Senedo pavo ncurvs & 2. \\
\hline C & 14 & $11-$ Dec-03 & Poa compressa & 1 \\
\hline $\mathrm{C}$ & 14 & 27-Feb-04 & Senecio pauperculus & 1 \\
\hline $\mathrm{c}$ & 25 & Bor Nover & Wyencum perforaturin & 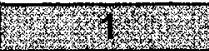 \\
\hline C & 25 & $18-J a n-04$ & Hypericum perforatum & 3 \\
\hline C & 25 & $01-F e b-04$ & Poa compressa & 1 \\
\hline e. & 30 & $20 \times 10 y$ & Hypencim perforating & 1 \\
\hline C & 30 & 20-Dec-03 & Fragaria virginiana & 1 \\
\hline C & 30 & 10-Jan-04 & Hypericum perforatum & 3 \\
\hline C & 30 & $21-J a n-04$ & Hypericum perforatum & 1 \\
\hline C & 30 & 24-Jan-04 & Fragaria virginiana & 1 \\
\hline (6. & 35 & $20100 \times 03$ & 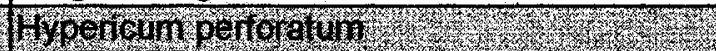 & 6 \\
\hline C & 35 & $06-$ Dec-03 & Euphorbia cyparissias & 2 \\
\hline C & 35 & 11-Dec-03 & Poa compressa & 2 \\
\hline C & 35 & 27-Dec-03 & Campanula rotundifolia & 1 \\
\hline C & 35 & $10-\operatorname{Jan}-04$ & Poa compressa & 1 \\
\hline $\mathrm{C}$ & 35 & 18-Jan-04 & Hypericum perforatum & 5 \\
\hline C & 35 & 18-Jan-04 & Fragaria virginiana & 1 \\
\hline C & 35 & $01-$ Feb-04 & Hypericum perforatum & 1 \\
\hline C. & 5 & $26-16 \times 63$ & Aoperstim pentorafinf & 3. \\
\hline $\mathrm{C}$ & 51 & 06-Dec-03 & Panicum linearifolium & 2 \\
\hline $\mathrm{C}$ & 51 & 11-Dec-03 & Poa compressa & 5 \\
\hline $\mathrm{C}$ & 51 & 11-Dec-03 & Chaenorrhinum minus & 1 \\
\hline C & 51 & $10-J a n-04$ & Deschampsia flexuosa & 1 \\
\hline 6 & 67 & (20 Nov $=0$ & Hitercuip perforatin & 8 \\
\hline C & 67 & 06-Dec-03 & Panicum linearifolium & 1 \\
\hline C & 67 & 11-Dec-03 & Echium vulgare & 1 \\
\hline $\mathrm{C}$ & 67 & 10-Jan-04 & Poa compressa & 1 \\
\hline C & 67 & 18-Jan-04 & Hypericum perforatum & 1 \\
\hline C & 67 & 24-Jan-04 & Hypericum perforatum & 1 \\
\hline C & 67 & 24-Jan-04 & Fragaria virginiana & 1 \\
\hline $\mathrm{C}$ & 67 & 24-Jan-04 & Campanula rotundifolia & 1 \\
\hline e & 68 & $20 \times 10 \times 03$ & Typoricum or rom & 2 \\
\hline (6) & 100 & 12010003 & Wypereum oertoratwit & 3 \\
\hline D & 0 & $20-$ Nov-03 & Leucanthemum vulgare & 1 \\
\hline D & 0 & $30-$ Nov-03 & Hypericum perforatum & 2 \\
\hline $\bar{D}$ & 0 & 06-Dec-03 & Verbascum thapsus & 1 \\
\hline D & 0 & 06-Dec-03 & Panicum linearifolium & 1 \\
\hline
\end{tabular}


92

\begin{tabular}{|c|c|c|c|c|}
\hline \multicolumn{5}{|c|}{ ppendix C: Soil Seed Bank Study Results Continued } \\
\hline Row & Plot & Date & Species & Quantity \\
\hline $\bar{D}$ & 0 & 11-Dec-03 & Poa compressa & 10 \\
\hline $\mathrm{D}$ & 0 & 20-Dec-03 & Fragaria virginiana & 4 \\
\hline D & 0 & 20-Dec-03 & Echium vulgare & 1 \\
\hline $\bar{D}$ & 0 & 27-Dec-03 & Senecio pauperculus & 1 \\
\hline D & 0 & 10-Jan-04 & Hypericum perforatum & 1 \\
\hline $\bar{D}$ & 0 & 24-Jan-04 & Poa compressa & 3 \\
\hline $\mathrm{D}$ & 0 & 24-Jan-04 & Fragaria virginiana & 1 \\
\hline D & 0 & $27-$ Feb-04 & Hypericum perforatum & 2 \\
\hline D & 0 & 27-Feb-04 & Fragaria virginiana & 3 \\
\hline D & 0 & $27-$ Feb-04 & Echium vulgare & 1 \\
\hline D & 4 & 10010y-03 & Wyperdeum perforafun & (1) \\
\hline $\mathrm{D}$ & 4 & $30-$ Nov-03 & Verbascum thapsus & 2 \\
\hline $\bar{D}$ & 4 & 11-Dec-03 & Poa compressa & 1 \\
\hline D & 4 & 20-Dec-03 & Hypericum perforatum & 1 \\
\hline$D$ & 4 & 20-Dec-03 & Oxalis stricta & 1 \\
\hline $\bar{D}$ & 4 & 27-Dec-03 & Scutellaria parvula & 1 \\
\hline $\mathrm{D}$ & 4 & 10-Jan-04 & Hypericum perforatum & 2 \\
\hline D & 4 & 18-Jan-04 & Oxalis stricta & 1 \\
\hline D & 4 & 18-Jan-04 & Hypericum perforatum & 1 \\
\hline$D$ & 4 & 18-Jan-04 & Echium vulgare & 2 \\
\hline $\mathrm{D}$ & 4 & 18-Jan-04 & Leucanthemum vulgare & 1 \\
\hline $\mathrm{D}$ & 4 & 21-Jan-04 & Hypericum perforatum & 1 \\
\hline $\mathrm{D}$ & 4 & 01-Feb-04 & Hypericum perforatum & 2 \\
\hline D & 4 & $01-\mathrm{Feb}-04$ & Senecio pauperculus & 1 \\
\hline$D$ & 4 & 08-Feb-04 & Scutellaria parvula & 1 \\
\hline D. & 8 & 106- Deco3 & Woperigumperroratum & 2 \\
\hline D & 8 & 11-Dec-03 & Poa compressa & 2 \\
\hline $\bar{D}$ & 8 & 20-Dec-03 & Fragaria virginiana & 1 \\
\hline $\mathrm{D}$ & 8 & 20-Dec-03 & Hypericum perforatum & 1 \\
\hline D & 8 & 10-Jan-04 & Solidago nemoralis & 2 \\
\hline D & 8 & 10-Jan-04 & Hypericum perforatum & 1 \\
\hline $\bar{D}$ & 8 & 18-Jan-04 & Hypericum perforatum & 3 \\
\hline $\bar{D}$ & 8 & 24-Jan-04 & Poa compressa & 1 \\
\hline $\mathrm{D}$ & 8 & 24-Jan-04 & Hypericum perforatum & 2 \\
\hline $\bar{D}$ & 8 & 08-Feb-04 & Solidago nemoralis & 1 \\
\hline $\bar{D}$ & 8 & 27-Feb-04 & Hypericum perforatum & 1 \\
\hline D. & 19.20 & 1301 Nov 03 & Hoproum peroranm & 5 \\
\hline $\mathrm{D}$ & 10 & $11-$ Dec-03 & Oxalis stricta & 1 \\
\hline $\bar{D}$ & 10 & 26-Dec-03 & Senecio pauperculus & 1 \\
\hline D & 10 & 10-Jan-04 & Hypericum perforatum & 4 \\
\hline D & 10 & 18-Jan-04 & Hypericum perforatum & 3 \\
\hline $\mathrm{D}$ & 10 & $01-$ Feb-04 & Senecio pauperculus & 1 \\
\hline $\mathrm{D}$ & 10 & 27-Feb-04 & Oxalis stricta & 1 \\
\hline D & 60: & 20.10y-03 & 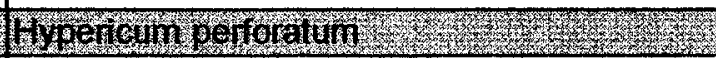 & 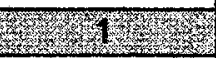 \\
\hline $\mathrm{D}$ & 50 & 06-Dec-03 & Verbascum thapsus & 1 \\
\hline
\end{tabular}




\begin{tabular}{|c|c|c|c|c|}
\hline \multicolumn{5}{|c|}{ Appendix C: Soil Seed Bank Study Results Continued } \\
\hline Row & Plot & Date & Species & Quantity \\
\hline D & 50 & $06-D e c-03$ & Panicum linearifolium & 1 \\
\hline D & 50 & 11-Dec-03 & Verbascum thapsus & 2 \\
\hline $\bar{D}$ & 50 & 10-Jan-04 & Senecio pauperculus & 2 \\
\hline D & 50 & 10-Jan-04 & Poa compressa & 2 \\
\hline D & 50 & 08-Feb-04 & Poa compressa & 1 \\
\hline 1 & 84 & 20110008 & Whorromperforatim & 6. \\
\hline D & 84 & $30-$ Nov-03 & Leucanthemum vulgare & 1 \\
\hline $\bar{D}$ & 84 & 11-Dec-03 & Poa compressa & 2 \\
\hline $\bar{D}$ & 84 & 27-Dec-03 & Hypericum perforatum & 1 \\
\hline D & 84 & 27-Dec-03 & Senecio pauperculus & 1 \\
\hline D & 84 & 27-Dec-03 & Oxalis stricta & 1 \\
\hline $\bar{D}$ & 84 & 10-Jan-04 & Hypericum perforatum & 4 \\
\hline $\bar{D}$ & 84 & 18-Jan-04 & Hypericum perforatum & 2 \\
\hline $\bar{D}$ & 84 & 24-Jan-04 & Hypericum perforatum & 1 \\
\hline D & 84 & 01-Feb-04 & Campanula rotundifolia & 1 \\
\hline $\mathrm{D}$ & 84 & 27-Feb-04 & Hypericum perforatum & 4 \\
\hline D & 85 & 20100103 & Whengumperoraw & 6 \\
\hline D & 85 & 06-Dec-03 & Hypericum perforatum & 3 \\
\hline D & 85 & 11-Dec-03 & Poa compressa & 2 \\
\hline $\bar{D}$ & 85 & 26-Dec-03 & Senecio pauperculus & 1 \\
\hline $\bar{D}$ & 85 & 27-Dec-03 & Campanula rotundifolia & 3 \\
\hline D & 85 & 10-Jan-04 & Hypericum perforatum & 3 \\
\hline D & 85 & 18-Jan-04 & Hypericum perforatum & 2 \\
\hline (2) & 86 & 20101603 & Dy pencuin per for alum & 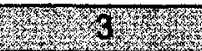 \\
\hline D & 86 & 06-Dec-03 & Oxalis stricta & 1 \\
\hline D & 86 & 11-Dec-03 & Poa compressa & 11 \\
\hline D & 86 & 20-Dec-03 & Senecio pauperculus & $\overline{1}$ \\
\hline D & 86 & 27-Dec-03 & Senecio pauperculus & 1 \\
\hline $\bar{D}$ & 86 & 27-Dec-03 & Campanula rotundifolia & 1 \\
\hline $\bar{D}$ & 86 & 10-Jan-04 & Danthonia spicata & 2 \\
\hline D & 86 & 18-Jan-04 & Hypericum perforatum & 1 \\
\hline$D$ & 86 & 18-Jan-04 & Senecio pauperculus & 1 \\
\hline D & 96 & S010v-03 & Wyoricum ochoralum & 1.4: \\
\hline D & 95 & 20-Dec-03 & Fragaria virginiana & 5 \\
\hline D & 95 & 10-Jan-04 & Poa compressa & 1 \\
\hline $\mathrm{D}$ & 95 & 10-Jan-04 & Hypericum perforatum & 1 \\
\hline$D$ & 95 & 18-Jan-04 & Fragaria virginiana & 3 \\
\hline D & 95 & 18-Jan-04 & Hieracium piloselloides & 1 \\
\hline$D$ & 95 & 24-Jan-04 & Poa compressa & 2 \\
\hline $\bar{D}$ & 95 & 24-Jan-04 & Fragaria virginiana & 1 \\
\hline D & 95 & 24-Jan-04 & Hieracium piloselloides & 1 \\
\hline D & 95 & $01-F e b-04$ & Fragaria virginiana & 1 \\
\hline 18 & 96 & $20100 y 08$ & Wyeroun perforatur & (2) \\
\hline D & 96 & $20-\mathrm{Nov}-03$ & Euphorbia cyparissias & 1 \\
\hline $\bar{D}$ & 96 & 30-Nov-03 & Verbascum thapsus & 4 \\
\hline
\end{tabular}




\begin{tabular}{|c|c|c|c|c|}
\hline \multicolumn{5}{|c|}{ Appendix C: Soil Seed Bank Study Results Continued } \\
\hline Row & Plot & Date & Species & Quantity \\
\hline D & 96 & 06-Dec-03 & Verbascum thapsus & 1 \\
\hline D & 96 & 11-Dec-03 & Poa compressa & 10 \\
\hline $\bar{D}$ & 96 & 11-Dec-03 & Hypericum perforatum & 2 \\
\hline $\bar{D}$ & 96 & 20-Dec-03 & Fragaria virginiana & 6 \\
\hline D & 96 & 20-Dec-03 & Hypericum perforatum & 1 \\
\hline $\bar{D}$ & 96 & 20-Dec-03 & Hieracium piloselloides & 1 \\
\hline $\bar{D}$ & 96 & 27-Dec-03 & Echium vulgare & 1 \\
\hline $\bar{D}$ & 96 & $10-\operatorname{Jan}-04$ & Rumex acetosella & 1 \\
\hline $\bar{D}$ & 96 & 18-Jan-04 & Fragaria virginiana & 4 \\
\hline $\mathrm{D}$ & 96 & 24-Jan-04 & Poa compressa & 1 \\
\hline $\bar{D}$ & 96 & $01-$ Feb-04 & Hypericum perforatum & 1 \\
\hline D & 96 & 27-Feb-04 & Hypericum perforatum & 1 \\
\hline E & 22 & $20110 \times 103$ & Ifyericum perforatini & 3. \\
\hline$E$ & 22 & 11-Dec-03 & Senecio pauperculus & 3 \\
\hline$E$ & 22 & 26-Dec-03 & Senecio pauperculus & 1 \\
\hline $\mathbf{E}$ & 22 & 27-Dec-03 & Campanula rotundifolia & 1 \\
\hline $\mathbf{E}$ & 22 & 10-Jan-04 & Hypericum perforatum & 1 \\
\hline $\bar{E}$ & 22 & 24-Jan-04 & Hypericum perforatum & 1 \\
\hline$E$ & 22 & 24-Jan-04 & Oxalis stricta & 1 \\
\hline$E$ & 22 & 27-Feb-04 & Hypericum perforatum & 2 \\
\hline$E$ & 23 & $30-$ Nov-03 & Hypericum perforatum & 1 \\
\hline$E$ & 23 & 11-Dec-03 & Hieracium piloselloides & 1 \\
\hline$E$ & 23 & 27-Dec-03 & Campanula rotundifolia & 2 \\
\hline $\bar{E}$ & 23 & 08-Feb-04 & Oxalis stricta & 1 \\
\hline 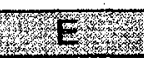 & 34 & $20.16 v-63$ & 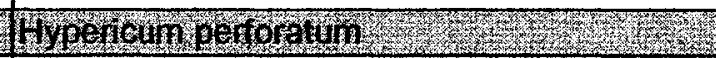 & 3 \\
\hline$E$ & 34 & $30-\mathrm{Nov}-03$ & Hypericum perforatum & 2 \\
\hline $\bar{E}$ & 34 & 06-Dec-03 & Panicum linearifolium & 1 \\
\hline$E$ & 34 & 11-Dec-03 & Poa compressa & 1 \\
\hline $\bar{E}$ & 34 & 20-Dec-03 & Fragaria virginiana & 4 \\
\hline $\bar{E}$ & 34 & 26-Dec-03 & Hypericum perforatum & 1 \\
\hline $\bar{E}$ & 34 & 10-Jan-04 & Campanula rotundifolia & 2 \\
\hline$E$ & 34 & 24-Jan-04 & Oxalis stricta & 2 \\
\hline$E$ & 34 & 24-Jan-04 & Hypericum perforatum & 1 \\
\hline $\bar{E}$ & 34 & 08-Feb-04 & Oxalis stricta & 1 \\
\hline$E$ & 34 & 08-Feb-04 & Poa compressa & 1 \\
\hline $\mathbf{E}$ & 34 & 08-Feb-04 & Hypericum perforatum & 1 \\
\hline E & 55 & $20 \mathrm{Nov} 0 \mathrm{0}$ & 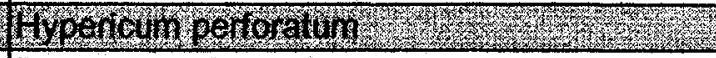 & 1 \\
\hline$E$ & 55 & 06-Dec-03 & Panicum linearifolium & 1 \\
\hline$E$ & 55 & 11-Dec-03 & Senecio pauperculus & 1 \\
\hline $\bar{E}$ & 55 & 27-Dec-03 & Oxalis stricta & 1 \\
\hline$E$ & 55 & 27-Dec-03 & Solidago nemoralis & 1 \\
\hline$E$ & 55 & 10-Jan-04 & Hypericum perforatum & 1 \\
\hline $\mathbf{E}$ & 55 & 18-Jan-04 & Oxalis stricta & 1 \\
\hline$E$ & 56. & $110 \mathrm{gecos}$ & Foa compressa & 11 \\
\hline$E$ & 56 & 18-Jan-04 & Oxalis stricta & 1 \\
\hline
\end{tabular}




\begin{tabular}{|c|c|c|c|c|}
\hline \multicolumn{5}{|c|}{ Appendix C: Soil Seed Bank Study Results Continued } \\
\hline Row & Plot & Date & Species & Quantity \\
\hline $\bar{E}$ & 56 & $08-F e b-04$ & Oxalis stricta & 1 \\
\hline E & 63 & 20 Nov 03 & Hyperioln perforatum & 3 \\
\hline$E$ & 63 & $30-$ NoV-03 & Hypericum perforatum & 1 \\
\hline$E$ & 63 & $06-D e c-03$ & Oxalis stricta & 3 \\
\hline $\mathrm{E}$ & 63 & 06-Dec-03 & Panicum linearifolium & 1 \\
\hline$E$ & 63 & 11-Dec-03 & Poa compressa & 1 \\
\hline $\bar{E}$ & 63 & 20-Dec-03 & Hypericum perforatum & 3 \\
\hline $\bar{E}$ & 63 & 20-Dec-03 & Senecio pauperculus & 2 \\
\hline$E$ & 63 & 26-Dec-03 & Echium vulgare & 1 \\
\hline$E$ & 63 & 27-Dec-03 & Senecio pauperculus & 2 \\
\hline $\bar{E}$ & 63 & 10-Jan-04 & Senecio pauperculus & 1 \\
\hline $\bar{E}$ & 63 & 10-Jan-04 & Poa compressa & 1 \\
\hline $\bar{E}$ & 63 & 18-Jan-04 & Echium vulgare & 1 \\
\hline$E$ & 63 & 24-Jan-04 & Poa compressa & 1 \\
\hline $\bar{E}$ & 63 & 08-Feb-04 & Hypericum perforatum & 2 \\
\hline$E$ & 71 & 20. Novero & Dyperieum peroranim & 2 \\
\hline$E$ & 71 & $30-$ Nov-03 & Hypericum perforatum & 1 \\
\hline $\mathbf{E}$ & 71 & 11-Dec-03 & Chaenorrhinum minus & 1 \\
\hline$E$ & 71 & 20-Dec-03 & Hypericum perforatum & 1 \\
\hline$E$ & 74 & 27-Dec-03 & Campanula rotundifolia & 1 \\
\hline $\bar{E}$ & 71 & 27-Dec-03 & Senecio pauperculus & 3 \\
\hline $\bar{E}$ & 71 & 27-Dec-03 & Hypericum perforatum & 1 \\
\hline$E$ & 71 & $01-F e b-04$ & Leucanthemum vulgare & 1 \\
\hline $\mathbf{E}$ & $\overline{71}$ & $27-F e b-04$ & Poa compressa & 1 \\
\hline $\bar{E}$ & 71 & 27-Feb-04 & Senecio pauperculus & $\overline{1}$ \\
\hline EF: & 178 & 20.No108 & Gypergumperforaturn & 1 1 (1 \\
\hline$E$ & 78 & 06-Dec-03 & Poa compressa & 1 \\
\hline$E$ & 78 & 11-Dec-03 & Poa compressa & 2 \\
\hline$E$ & 78 & 24-Jan-04 & Hypericum perforatum & 1 \\
\hline $\bar{E}$ & 78 & 27-Feb-04 & Hypericum perforatum & 5 \\
\hline $\bar{E}$ & 78 & 27-Feb-04 & Panicum linearifolium & 1 \\
\hline $\mathbf{E}$ & 78 & 27-Feb-04 & Echium vulgare & 1 \\
\hline E: & 81 & $10 \operatorname{Tan} 04$ & Senecio paporculus & 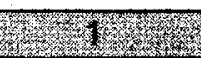 \\
\hline$E$ & 81 & 18-Jan-04 & Senecio pauperculus & 1 \\
\hline$E$ & 81 & $18-J a n-04$ & Oxalis stricta & 1 \\
\hline $\mathbf{E}$ & 81 & 24-Jan-04 & Senecio pauperculus & 1 \\
\hline $\bar{E}$ & 81 & $01-F e b-04$ & Verbascum thapsus & 1 \\
\hline es & 98 & $20110 y=3$ & 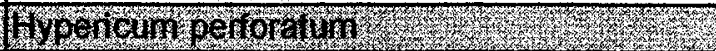 & 2 \\
\hline$E$ & 98 & 10-Jan-04 & Hypericum perforatum & 2 \\
\hline $\bar{E}$ & 98 & 01-Feb-04 & Leucanthemum vulgare & 2 \\
\hline$F$ & 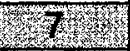 & 201100.03 & Wy perigum pertoratin & Pryty \\
\hline $\mathbf{F}$ & 7 & 11-Dec-03 & Poa compressa & 2 \\
\hline $\bar{F}$ & 7 & 20-Dec-03 & Senecio pauperculus & 1 \\
\hline $\bar{F}$ & 7 & 27-Dec-03 & Scutellaria parvula & $\overline{1}$ \\
\hline $\mathrm{F}$ & 7 & 10-Jan-04 & Hypericum perforatum & 1 \\
\hline
\end{tabular}


96

\begin{tabular}{|c|c|c|c|c|}
\hline \multicolumn{5}{|c|}{ Appendix C: Soil Seed Bank Study Results Continued } \\
\hline Row & Plot & Date & Species & Quantity \\
\hline ris & 16 & 20 Nover & Moe revim serforaturn & 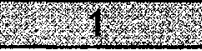 \\
\hline$F$ & 16 & 06-Dec-03 & Oxalis stricta & 1 \\
\hline $\bar{F}$ & 16 & 27-Dec-03 & Senecio pauperculus & 1 \\
\hline$F$ & 16 & 10-Jan-04 & Danthonia spicata & 1 \\
\hline$F$ & 16 & 24-Jan-04 & Poa compressa & 1 \\
\hline $\mathbf{F}$ & 16 & $01-F e b-04$ & Verbascum thapsus & 1 \\
\hline Fin & 26. & 20210403 & Hoeriom perforalun & 6 \\
\hline $\mathrm{F}$ & 20 & 06-Dec-03 & Hypericum perforatum & 2 \\
\hline $\mathbf{F}$ & 20 & 11-Dec-03 & Senecio pauperculus & 3 \\
\hline$F$ & 20 & 10-Jan-04 & Deschampsia flexuosa & 4 \\
\hline $\bar{F}$ & 20 & 18-Jan-04 & Hypericum perforatum & 1 \\
\hline$F$ & 20 & 24-Jan-04 & Senecio pauperculus & 1 \\
\hline$F$ & 20 & $01-F e b-04$ & Poa compressa & 1 \\
\hline $\mathrm{F}$ & 36. & 204 Novo3 & 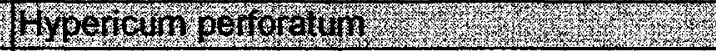 & Why \\
\hline $\bar{F}$ & 36 & 06-Dec-03 & Panicum linearifolium & 2 \\
\hline$F$ & 36 & $11-$ Dec-03 & Senecio pauperculus & 1 \\
\hline$F$ & 36 & 18-Jan-04 & Hypericum perforatum & 4 \\
\hline$F$ & 36 & 18-Jan-04 & Oxalis stricta & 1 \\
\hline$F$ & 36 & 18-Jan-04 & Senecio pauperculus & 3 \\
\hline$F$ & 36 & 27-Feb-04 & Hypericum perforatum & 1 \\
\hline f & 56 & $20110 \times 03$ & 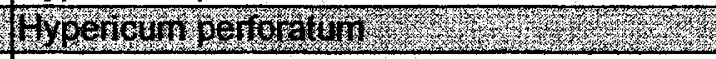 & 6 \\
\hline$F$ & 56 & 20-Nov-03 & Leucanthemum vulgare & 1 \\
\hline $\mathbf{F}$ & 56 & $20-$ Nov-03 & Verbascum thapsus & 1 \\
\hline$F$ & 56 & 06-Dec-03 & Verbascum thapsus & 1 \\
\hline $\bar{F}$ & 56 & 11-Dec-03 & Poa compressa & $\overline{14}$ \\
\hline$F$ & 56 & 20-Dec-03 & Fragaria virginiana & 6 \\
\hline $\mathrm{F}$ & 56 & 20-Dec-03 & Hypericum perforatum & 1 \\
\hline$F$ & 56 & 27-Dec-03 & Hypericum perforatum & 1 \\
\hline$F$ & 56 & 10-Jan-04 & Solidago nemoralis & 1 \\
\hline$F$ & 56 & 10-Jan-04 & Poa compressa & 1 \\
\hline $\bar{F}$ & 56 & 18-Jan-04 & Fragaria virginiana & 2 \\
\hline $\mathbf{F}$ & 56 & 18-Jan-04 & Hypericum perforatum & 1 \\
\hline $\bar{F}$ & 56 & 24-Jan-04 & Poa compressa & 3 \\
\hline$F$ & 56 & 24-Jan-04 & Hypericum perforatum & 1 \\
\hline$F$ & 56 & $01-F e b-04$ & Verbascum thapsus & 1 \\
\hline F & 64 & $2010 y-03$ & Verbascuminapsys & (1) \\
\hline$F$ & 64 & $30-$ Nov-03 & Hypericum perforatum & 2 \\
\hline$F$ & 64 & $11-$ Dec-03 & Senecio pauperculus & 1 \\
\hline$F$ & 64 & 20-Dec-03 & Fragaria virginiana & 1 \\
\hline$F$ & 64 & 27-Dec-03 & Campanula rotundifolia & 1 \\
\hline $\mathbf{F}$ & 64 & 18-Jan-04 & Fragaria virginiana & 1 \\
\hline $\mathbf{F}$ & 64 & 18-Jan-04 & Hypericum perforatum & 1 \\
\hline$F$ & 64 & 08-Feb-04 & Oxalis stricta & 1 \\
\hline F & 76 & 30.1101:08 & 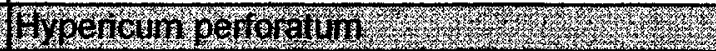 & 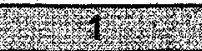 \\
\hline $\mathbf{F}$ & 76 & 06-Dec-03 & Hypericum perforatum & 1 \\
\hline
\end{tabular}


97

\begin{tabular}{|c|c|c|c|c|}
\hline \multicolumn{5}{|c|}{ Appendix C: Soil Seed Bank Study Results Continued } \\
\hline Row & Plot & Date & Species & Quantity \\
\hline $\bar{F}$ & 76 & 20-Dec-03 & Fragaria virginiana & 1 \\
\hline $\bar{F}$ & 76 & 27-Dec-03 & Hypericum perforatum & 1 \\
\hline$F$ & 76 & 18-Jan-04 & Hypericum perforatum & 2 \\
\hline$F$ & 76 & 24-Jan-04 & Oxalis stricta & 1 \\
\hline $\bar{F}$ & 76 & 08-Feb-04 & Poa compressa & 2 \\
\hline $\bar{F}$ & 76 & 27-Feb-04 & Oxalis stricta & 1 \\
\hline TP & 79 & Wogor & Porodorossa & 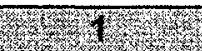 \\
\hline $\mathrm{F}$ & 79 & $10-J a n-04$ & Deschampsia flexuosa & 1 \\
\hline $\bar{F}$ & 79 & 10-Jan-04 & Hypericum perforatum & 2 \\
\hline $\mathbf{F}$ & 79 & 18-Jan-04 & Senecio pauperculus & 3 \\
\hline $\bar{F}$ & 79 & 24-Jan-04 & Oxalis stricta & 1 \\
\hline $\bar{F}$ & 79 & 24-Jan-04 & Hypericum perforatum & 1 \\
\hline $\mathrm{F}^{2}$ & 8 & 1. Doded & Pojoompressa & 82 \\
\hline $\mathbf{F}$ & 81 & 18-Jan-04 & Senecio pauperculus & 1 \\
\hline 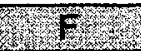 & 97 & 2610003 & 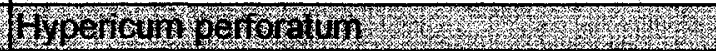 & 3 \\
\hline$F$ & 97 & $30-$ Nov-03 & Hypericum perforatum & 6 \\
\hline$F$ & 97 & 06-Dec-03 & Panicum linearifolium & 1 \\
\hline$F$ & 97 & 11-Dec-03 & Senecio pauperculus & 2 \\
\hline $\mathbf{F}$ & 97 & 11-Dec-03 & Poa compressa & 1 \\
\hline $\bar{F}$ & 97 & 20-Dec-03 & Melilotus alba & 1 \\
\hline $\bar{F}$ & 97 & 10-Jan-04 & Scutellaria parvula & 1 \\
\hline$F$ & 97 & 10-Jan-04 & Hypericum perforatum & 2 \\
\hline$F$ & 97 & 24-Jan-04 & Oxalis stricta & 1 \\
\hline
\end{tabular}




\section{Appendix D: Vegetation Survey Results}

\begin{tabular}{|c|c|c|c|}
\hline Plot & Species & Plot & Species \\
\hline A33 & Danibonia spicata & $\mathrm{A} 60$ & Senecio pauperculus \\
\hline A33 & Rosa blanda & A60 & Solidago nemoralis \\
\hline A33 & Panicum linearifolium & $\mathrm{A} 60$ & Penstemon hirsutus \\
\hline A33 & Poa compressa & $\overline{\mathrm{A} 60}$ & Scutellaria parvula \\
\hline$\overline{A 33}$ & Carex richardsonii & A61 & Poterina reck \\
\hline A33 & Antennaria howellii & A61 & Hieracium piloselloides \\
\hline A33 & Ceanothus americanus & A61 & Senecio pauperculus \\
\hline A33 & Leucanthemum vulgare & A61 & Solidago nemoralis \\
\hline A37 & Prinus virginian & A61 & Poa compressa \\
\hline $\mathrm{A} 37$ & Danthonia spicata & A61 & Danthonia spicata \\
\hline A37 & Solidago spp. & A61 & Carex umbellata \\
\hline A37 & Leucanthemum vulgare & A61 & Sporobolus vaginiflorus \\
\hline A37 & Poa compressa & 162 & Elphorba cyparissias \\
\hline A37 & Carex crawei & A62 & Danthonia spicata \\
\hline A37 & Panicum linearifolium & A62 & Hieracium piloselloides \\
\hline$\overline{A 37}$ & Fragaria virginiana & $\overline{A 62}$ & Poa compressa \\
\hline A37 & Rhamnus catharticus & $\overline{A 62}$ & Sporobolus vaginiflorus \\
\hline A37 & Hieracium piloselloides & A62 & Scutellaria panula \\
\hline A37 & Hypericum perforatum & A62 & Solidago nemoralis \\
\hline A37 & Campanula rotundifolia & A62 & Panicum linearifolium \\
\hline$\overline{A 37}$ & Unknown species & A62 & Unknown species \\
\hline A37 & Potentilla recta & 170 & Euphorbja cyparissias \\
\hline A37 & Bromus kalmii & A70 & Danthonia spicata \\
\hline A37 & Solidago nemoralis & $\overline{A 70}$ & Scutellaria parvula \\
\hline$A 4$ & Poa comprossa & A70 & Panicum linearifolium \\
\hline A43 & Danthonia spicata & A70 & Solidago nemoralis \\
\hline A43 & Sporobolus vaginiflorus & A70 & Sporobolus vaginiflorus \\
\hline A43 & Scutellaria parvula & A70 & Isanthus brachiatus \\
\hline A43 & Solidago nemoralis & 189 & Poa compressa \\
\hline A19. & Danowaspiata & A89 & Danthonia spicata \\
\hline A49 & Poa compressa & A89 & Agrostis spp \\
\hline A49 & Senecio pauperculus & A89 & Rhus radicans \\
\hline A49 & Solidago nemoralis & $\overline{A 89}$ & Antennaria howellii \\
\hline A49 & Carex aurea & A89 & Hieracium piloselloides \\
\hline A49 & Scutellaria parvula & A89 & Solidago nemoralis \\
\hline A49 & Antennaria howellii & A89 & Carex crawei \\
\hline A49 & Hieracium piloselloides & A89 & Scutellaria parvula \\
\hline A60 & 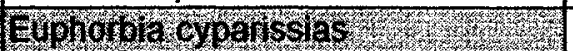 & A89 & Fragaria virginiana \\
\hline A60 & Leucanthemum vulgare & A89 & Vicia cracca \\
\hline $\mathrm{A60}$ & Campanula rotundifolia & A97 & Pancum lnearioning \\
\hline A60 & Danthonia spicata & A97 & Danthonia spicata \\
\hline A60 & Poa compressa & A97 & Rhus radicans \\
\hline
\end{tabular}




\begin{tabular}{|c|c|c|c|}
\hline \multicolumn{4}{|c|}{ Appendix D: Vegetation Survey Results Continued } \\
\hline Plot & Species & Plot & Species \\
\hline $\mathrm{A} 60$ & Hieracium piloselloides & A97 & Hieracium piloselloides \\
\hline A60 & Potentilla recta & $\overline{\mathrm{A} 97}$ & Solidago nemoralis \\
\hline A97 & Carex crawei & $\mathrm{B} 58$ & Scutellaria parvula \\
\hline A97 & Scutellaria parvula & B58 & Carex aurea \\
\hline A97 & Fragaria virginiana & B58 & Fragaria virginiana \\
\hline (B22. & 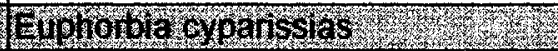 & B58 & Carex crawei \\
\hline B22 & Fragaria virginiana & B58 & Chaenorrhimum minus \\
\hline B22 & Senecio pauperculus & B58 & Panicum linearifolium \\
\hline B22 & Scutellaria parvula & B58 & Danthonia spicata \\
\hline $\mathrm{B} 22$ & Solidago nemoralis & 858 & Campanula rotundifolia \\
\hline B22 & Poa compressa & B58 & Solidago nemoralis \\
\hline B22 & Danthonia spicata & B58 & Leucanthemum vulgare \\
\hline B22 & Campanula rotundifolia & B58 & Hieracium piloselloides \\
\hline $\mathrm{B} 22$ & Leucanthemum vulgare & $B 60$ & Eqpionola Gipanssias \\
\hline B22 & Hieracium piloselloides & $\mathrm{B} 60$ & Melilotus alba \\
\hline ges & Euphoira cyparisslas & $\mathrm{B} 60$ & Carex richardsonii \\
\hline B23 & Melilotus alba & $\mathrm{B} 60$ & Linaria vulgaris \\
\hline B23 & Potentilla recta & 861 & 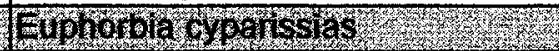 \\
\hline B23 & Daucus carota & $\mathrm{B} 61$ & Danthonia spicata \\
\hline B23 & Leucanthemum vulgare & $\mathrm{B} 61$ & Trifolium aureum \\
\hline B23 & Senecio pauperculus & B61 & Fragaria virginiana \\
\hline $\mathrm{B} 23$ & Scutellaria parvula & B61 & Hieracium piloselloides \\
\hline $\mathrm{B} 23$ & Hypericum perforatum & B61 & Campanula rotundifolia \\
\hline$B 23$ & Poa compressa & B61 & Solidago nemoralis \\
\hline $\mathrm{B} 23$ & Trifolium aureum & B61 & Melilotus alba \\
\hline B23 & Fragaria virginiana & B61 & Panicum linearifolium \\
\hline B23 & Danthonia spicata & B61 & Hypericum perforatum \\
\hline $\mathrm{B} 23$ & Hieracium piloselloides & $\overline{B 61}$ & Bromus kalmii \\
\hline 68 & 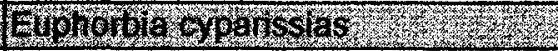 & B78 & 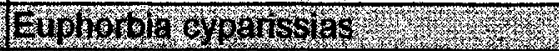 \\
\hline B38 & Poa compressa & B78 & Prunella vulgaris \\
\hline B38 & Danthonia spicata & $\overline{B 78}$ & Solidago nemoralis \\
\hline B38 & Solidago nemoralis & B78 & Carex aurea \\
\hline B38 & Penstemon hirsutus & $\overline{B 78}$ & Fragaria virginiana \\
\hline B38 & Leucanthemum vulgare & B78 & Vicia cracca \\
\hline B38 & Senecio pauperculus & B78 & Rhus radicans \\
\hline B38 & Sporobolus vaginiflorus & B78 & Melilotus alba \\
\hline B38 & Hypericum perforatum & B78 & Viola spp \\
\hline B38 & Unknown species & B78 & Panicum linearifolium \\
\hline 841 & 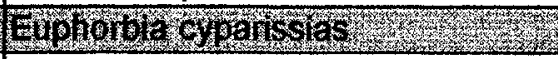 & B78 & Danthonia spicata \\
\hline B41 & Rosa blanda & B78 & Poa compressa \\
\hline B41 & Echium vulgare & $B 78$ & Equisetum arvense \\
\hline B41 & Panicum linearifolium & B89. & Sminocing stella lat \\
\hline B41 & Danthonia spicata & B89 & Campanula rotundifolia \\
\hline B41 & Carex richardsonii & B89 & Danthonia spicata \\
\hline
\end{tabular}


100

\begin{tabular}{|c|c|c|c|}
\hline \multicolumn{4}{|c|}{ Appendix D: Vegetation Survey Results Continued } \\
\hline Plot & Species & Plot & Species \\
\hline B41 & Solidago nemoralis & B89 & Carex crawei \\
\hline B41 & Hieracium piloselloides & B89 & Carex richardsonii \\
\hline B41 & Penstemon hirsutus & B89 & Panicum linearifolium \\
\hline B41 & Poa compressa & B89 & Hieracium piloselloides \\
\hline 856 & Euphorbia oyparssias & $\mathrm{B} 89$ & Solidago nemoralis \\
\hline 690 & Elohor Th oporissias & C11 & Hieracium piloselloides \\
\hline B93 & Maianthemum canadense & C11 & Aster cordifolius \\
\hline $\mathrm{B} 93$ & Echium vulgare & C11 & Solidago ptarmicoides \\
\hline$\overline{B 93}$ & Campanula rotundifolia & e14 & Euphorbla gor issiag \\
\hline$\overline{B 93}$ & Melilotus alba & C14 & Panicum linearifolium \\
\hline $\mathrm{B93}$ & Carex crawei & C14 & Danthonia spicata \\
\hline B93 & Carex richardsonii & C14 & Antennaria howellii \\
\hline B93 & Hieracium piloselloides & C14 & Hieracium piloselloides \\
\hline $\mathrm{B} 93$ & Trifolium aureum & C14 & Sporobolus vaginiflorus \\
\hline B93 & Antennaria howellii & C14 & Scutellaria parvula \\
\hline B93 & Vicia cracca & C14 & Carex crawei \\
\hline B93 & Solidago nemoralis & C25 & Euphorora owprissias \\
\hline B93 & Poa compressa & $\mathrm{C} 25$ & Poa compressa \\
\hline B93 & Danthonia spicata & $\mathrm{C25}$ & Danthonia spicata \\
\hline$\overline{B 93}$ & Panicum linearifolium & $\mathrm{C} 25$ & Campanula rotundifolia \\
\hline$\overline{B 93}$ & Senecio pauperculus & $\mathrm{C} 25$ & Hieracium piloselloides \\
\hline B93 & Leucanthemum vulgare & $\mathrm{C} 25$ & Carex crawei \\
\hline 60. & 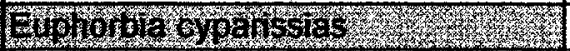 & $\mathrm{C25}$ & Panicum linearifolium \\
\hline $\mathrm{CO}$ & Senecio pauperculus & $\mathrm{C25}$ & Carex richardsonii \\
\hline $\mathrm{CO}$ & Hieracium piloselloides & $\mathrm{C25}$ & Solidago nemoralis \\
\hline $\mathrm{CO}$ & Linaria vulgaris & 1930 & 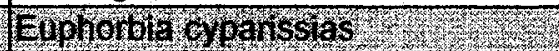 \\
\hline $\mathrm{CO}$ & Poa compressa & C30 & Campanula rotundifolia \\
\hline $\mathrm{CO}$ & Danthonia spicata & $\mathrm{C} 30$ & Danthonia spicata \\
\hline $\mathrm{CO}$ & Panicum linearifolium & C30 & Senecio pauperculus \\
\hline $\mathrm{CO}$ & Fragaria virginiana & C30 & Scutellaria parvula \\
\hline $\mathrm{CO}$ & Aster cordifolius & $\mathrm{C} 30$ & Potentilla recta \\
\hline $\mathrm{CO}$ & Leucanthemum vulgare & C30 & Sporobolus vaginiflorus \\
\hline $\mathrm{CO}$ & Daucus carota & es5 & Euphorow cypanssigs \\
\hline $\mathrm{CO}$ & Hypericum perforatum & C35 & Danthonia spicata \\
\hline Cto & Prinetravolgons & C35 & Carex crawei \\
\hline C10 & Leucanthemum vulgare & C35 & Poa compressa \\
\hline C10 & Poa compressa & $\overline{C 35}$ & Scutellaria parvula \\
\hline C10 & Carex crawei & $\mathrm{C} 35$ & Penstemon hirsutus \\
\hline C10 & Melilotus alba & C35 & Potentilla recta \\
\hline C10 & Scutellaria parvula & $\mathrm{C} 35$ & Sporobolus vaginiflorus \\
\hline C10 & Danthonia spicata & C35 & Panicum linearifolium \\
\hline $\mathrm{C} 10$ & Panicum linearifolium & C35 & Senecio pauperculus \\
\hline C10 & Fragaria virginiana & 251 & 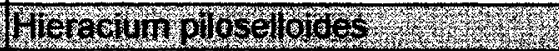 \\
\hline C10 & Penstemon hirsutus & C51 & Senecio pauperculus \\
\hline
\end{tabular}


101

\begin{tabular}{|c|c|c|c|}
\hline \multicolumn{4}{|c|}{ Appendix D: Vegetation Survey Results Continued } \\
\hline Plot & Species & Plot & Species \\
\hline $\mathrm{C10}$ & Hypericum perforatum & C51 & Sporobolus vaginiflorus \\
\hline Q11 & Menorbia cypanissiass & C51 & Danthonia spicata \\
\hline $\mathrm{C} 11$ & Panicum linearifolium & $\mathrm{C51}$ & Poa compressa \\
\hline $\mathrm{C11}$ & Senecio pauperculus & $\mathrm{C51}$ & Fragaria virginiana \\
\hline C11 & Carex crawei & C51 & Panicum linearifolium \\
\hline C11 & Danthonia spicata & $\mathrm{C51}$ & Solidago nemoralis \\
\hline $\mathrm{C11}$ & Sporobolus vaginiflorus & C51 & Ambrosia artemisiifolia \\
\hline C11 & Unknown species & 667 & 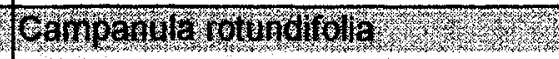 \\
\hline C67 & Senecio pauperculus & D10 & Campanula rotundifolia \\
\hline C67 & Poa compressa & D10 & Hieracium piloselloides \\
\hline $\mathrm{C67}$ & Danthonia spicata & D10 & Solidago nemoralis \\
\hline $\mathrm{C67}$ & Scutellaria parvula & D50 & Elplorbia gyonissias \\
\hline$\overline{C 67}$ & Leucanthemum vulgare & D50 & Smilacina stellata \\
\hline C67 & Sporobolus vaginiflorus & D50 & Fragaria virginiana \\
\hline$\overline{C 67}$ & Solidago nemoralis & D50 & Carex richardsonii \\
\hline C67 & Rhus typhina & D50 & Panicum linearifolium \\
\hline 2068. & Danivona spocato & D50 & Senecio pauperculus \\
\hline $\mathrm{C88}$ & Poa compressa & D50 & Solidago nemoralis \\
\hline $\mathrm{C88}$ & Panicum linearifolium & D50 & Hieracium piloselloides \\
\hline $\mathrm{C} 88$ & Solidago nemoralis & D50 & Isanthus brachiatus \\
\hline $\mathrm{C88}$ & Senecio pauperculus & 2084 & 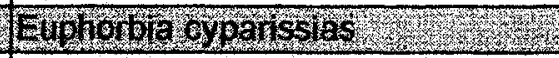 \\
\hline Tho & 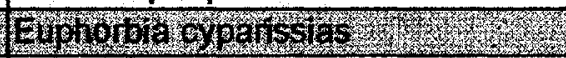 & D84 & Danthonia spicata \\
\hline DO & Poa compressa & $\mathrm{D} 84$ & Penstemon hirsutus \\
\hline DO & Melilotus alba & $\overline{D 84}$ & Poa compressa \\
\hline Do & Rosa blanda & $\overline{D 84}$ & Senecio pauperculus \\
\hline DO & Solidago nemoralis & D84 & Solidago nemoralis \\
\hline Dir & 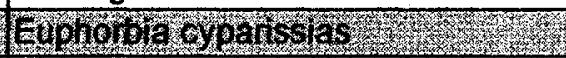 & D84 & Carex umbellata \\
\hline D4 & Danthonia spicata & $\overline{D 84}$ & Campanula rotundifolia \\
\hline D4 & Echium vulgare & 085 & 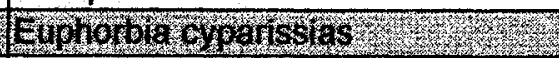 \\
\hline D4 & Solidago spp. & D85 & Carex umbellata \\
\hline$\overline{D 4}$ & Trifolium aureum & $\overline{D 85}$ & Senecio pauperculus \\
\hline$\overline{D 4}$ & Solidago ptamicoides & D85 & Danthonia spicata \\
\hline D4 & Poa compressa & D85 & Hieracium piloselloides \\
\hline D4 & Hieracium piloselloides & D85 & Poa compressa \\
\hline D4 & Senecio pauperculus & D86 & 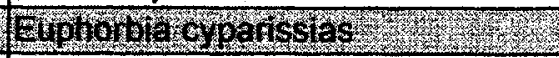 \\
\hline D4 & Panicum linearifolium & D86 & Solidago ptarmicoides \\
\hline D4 & Solidago nemoralis & D86 & Danthonia spicata \\
\hline 86. & 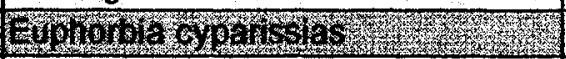 & $\mathrm{D} 86$ & Senecio pauperculus \\
\hline $\mathrm{D} 8$ & Danthonia spicata & D86 & Carex umbellata \\
\hline D8 & Panicum linearifolium & D86 & Isanthus brachiatus \\
\hline D8 & Carex umbellata & 095 & 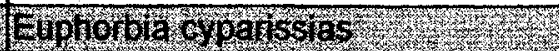 \\
\hline D8 & Senecio pauperculus & D95 & Solidago ptarmicoides \\
\hline$\overline{D 8}$ & Panicum linearifolium & D95 & Carex umbellata \\
\hline$\overline{\mathrm{D} 8}$ & Solidago nemoralis & $\overline{D 95}$ & Campanula rotundifolia \\
\hline
\end{tabular}


102

\begin{tabular}{|c|c|c|c|}
\hline \multicolumn{4}{|c|}{ Appendix D: Vegetation Survey Results Continued } \\
\hline Plot & Species & Plot & Species \\
\hline D8 & Campanula rotundifolia & D95 & Hieracium piloselloides \\
\hline D8 & Sisyrinchium montanum & D95 & Agrostis gigantea \\
\hline D10.2 & Wrininsalicaria & D95 & Senecio pauperculus \\
\hline D10 & Carex crawei & D95 & Echium vulgare \\
\hline D10 & Danthonia spicata & D95 & Ambrosia artemisiifolia \\
\hline D10 & Sisyrinchium montanum & 1096 & ETolorofa cy parssias \\
\hline D10 & Fragaria virginiana & D96 & Carex crawei \\
\hline D10 & Ambrosia artemisiifolia & D96 & Hieracium piloselloides \\
\hline D10 & Panicum linearifolium & D96 & Scutellaria parvula \\
\hline D10 & Prunella vulgaris & D96 & Unknown gramineae \\
\hline D10 & Senecio pauperculus & E22 & Soldago spp \\
\hline E22 & Danthonia spicata & E63 & Carex richardsonii \\
\hline E22 & Panicum linearifolium & E63 & Solidago ptamicoides \\
\hline E22 & Hieracium piloselloides & E63 & Scutellaria parvula \\
\hline E22 & Fragaria virginiana & E71 & 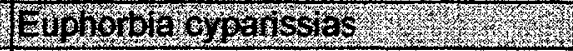 \\
\hline E22 & Senecio pauperculus & E71 & Poa compressa \\
\hline E22 & Carex richardsonii & E71 & Scutellaria parvula \\
\hline E28 & Danfonis splealas & E71 & Agrostis spp. \\
\hline E23 & Carex aurea & E71 & Danthonia spicata \\
\hline E23 & Panicum linearifolium & E71 & Carex richardsonii \\
\hline E23 & Solidago ptarmicoides & E71 & Senecio pauperculus \\
\hline E23 & Senecio pauperculus & E71 & Chaenorrhinum minus \\
\hline E23 & Aster cordifolius & E71 & Sporobolus vaginiflorus \\
\hline E23 & Hieracium piloselloides & E71 & Solidago nemoralis \\
\hline P87 & Baithonis spicate, & E71 & Echium vulgare \\
\hline E34 & Panicum linearifolium & E76 & Sonedo povorowing \\
\hline E34 & Senecio pauperculus & E78 & Carex crawei \\
\hline E34 & Isanthus brachiatus & E78 & Danthonia spicata \\
\hline E34 & Prunella vulgaris & E78 & Hieracium piloselloides \\
\hline E34 & Carex aurea & E78 & Sporobolus vaginiflorus \\
\hline E34 & Solidago ptarmicoides & E78 & Solidago nemoralis \\
\hline E34 & Solidago nemoralis & E78 & Prunella vulgaris \\
\hline E34 & Agropyron trachycaulum & ER & 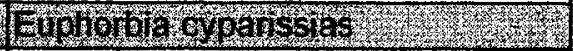 \\
\hline E5638 & Euphorba gyarias; & E81 & Smilacina stellata \\
\hline E55 & Danthonia spicata & E81 & Senecio pauperculus \\
\hline E55 & Solidago ptarmicoides & E81 & Carex crawei \\
\hline E55 & Smilacina stellata & E81 & Carex richardsonii \\
\hline E55 & Hieracium piloselloides & E81 & Panicum linearifolium \\
\hline E55 & Echium vulgare & E81 & Solidago nemoralis \\
\hline E55 & Panicum linearifolium & E81 & Hieracium piloselloides \\
\hline E55 & Senecio pauperculus & E81 & Danthonia spicata \\
\hline E55 & Sporobolus vaginiflorus & E81 & Sporobolus vaginiflorus \\
\hline E55 & Unknown species & E.58 & 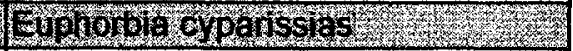 \\
\hline 56 & S Swlacina steilata & E98 & Echium vulgare \\
\hline
\end{tabular}




\begin{tabular}{|c|c|c|c|}
\hline \multicolumn{4}{|c|}{ Appendix D: Vegetation Survey Results Continued } \\
\hline Plot & Species & Plot & Species \\
\hline$E 56$ & Senecio pauperculus & E98 & Carex richardsonii \\
\hline$E 56$ & Solidago ptarmicoides & E98 & Danthonia spicata \\
\hline E56 & Panicum linearifolium & E98 & Solidago nemoralis \\
\hline E56 & Sporobolus vaginiflorus & E98 & Solidago spp. \\
\hline E56 & Carex richardsonii & E98 & Hypericum perforatum \\
\hline E56 & Carex umbellata & E98 & Panicum linearifolium \\
\hline$E 56$ & Prunella vulgaris & E98 & Poa compressa \\
\hline E63 & 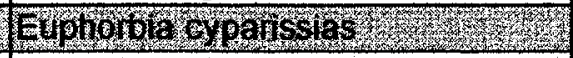 & E98 & Fragaria virginiana \\
\hline E63 & Poa compressa & E98 & Campanula rotundifolia \\
\hline$E 63$ & Danthonia spicata & E98 & Carex crawei \\
\hline$E 63$ & Solidago nemoralis & E98 & Antennaria howellii \\
\hline E63 & Hieracium piloselloides & Fi: & Darithona spich \\
\hline$\overline{E 63}$ & Senecio pauperculus & F7 & Carex crawei \\
\hline E63 & Panicum linearifolium & F7 & Panicum linearifolium \\
\hline F7 & Poa compressa & F64 & Potentilla recta \\
\hline F7 & Senecio pauperculus & (x) 16 & Danhonu solcath \\
\hline F7 & Hieracium piloselloides & F76 & Panicum linearifolium \\
\hline F7 & Sporobolus vaginiflorus & F76 & Scutellaria parvula \\
\hline F7 & Ambrosia artemisiifolia & F76 & Senecio pauperculus \\
\hline 16 & 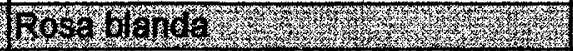 & F76 & Sporobolus vaginiflorus \\
\hline F16 & Solidago ptarmicoides & F76 & Carex crawei \\
\hline F16 & Leucanthemum vulgare & F76 & Carex richardsonii \\
\hline F16 & Hieracium piloselloides & F76 & Hieracium piloselloides \\
\hline F16 & Prunella vulgaris & F76 & Solidago ptarmicoides \\
\hline F16 & Antennaria howellii & F76 & Antennaria howellii \\
\hline F16 & Senecio pauperculus & If & Carex Grom \\
\hline F16 & Panicum linearifolium & F79 & Solidago ptamicoides \\
\hline F16 & Polygala senega & F79 & Sporobolus vaginiflorus \\
\hline F20 & 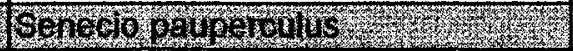 & F79 & Senecio pauperculus \\
\hline $\mathrm{F} 20$ & Solidago spp. & F79 & Antennaria howellii \\
\hline F20 & Danthonia spicata & F79 & Scutellaria parvula \\
\hline $\mathrm{F} 20$ & Antennaria howellii & F79 & Unknown species \\
\hline F20 & Hieracium piloselloides & F79 & Danthonia spicata \\
\hline $\mathrm{F} 20$ & Sporobolus vaginiflorus & F79 & Campanula rotundifolia \\
\hline $\mathrm{F} 20$ & Scutellaria parvula & Fol & Garowawel \\
\hline F20 & Panicum linearifolium & $\mathrm{F} 81$ & Smilacina stellata \\
\hline F20 & Carex crawei & F81 & Danthonia spicata \\
\hline 76 & Senecio o auporonus & $\mathbf{F 8 1}$ & Hieracium piloselloides \\
\hline F36 & Smilacina stellata & F81 & Aster cordifolius \\
\hline F36 & Panicum linearifolium & $\overline{F 81}$ & Prunella vulgaris \\
\hline F36 & Danthonia spicata & F81 & Sporobolus vaginiflorus \\
\hline$\overline{F 36}$ & Sporobolus vaginiflorus & F81 & Panicum linearifolium \\
\hline F36 & Carex umbellata & F81 & Senecio pauperculus \\
\hline res6 & Prunello Wugans & 707 & 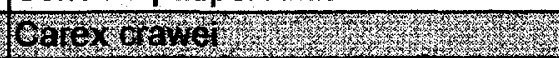 \\
\hline
\end{tabular}




\begin{tabular}{|c|c|c|c|}
\hline \multicolumn{4}{|c|}{ Appendix D: Vegetation Survey Results Continued } \\
\hline Plot & Species & Plot & Species \\
\hline F56 & Danthonia spicata & F97 & Fragaria virginiana \\
\hline F56 & Solidago spp. & F97 & Smilacina stellata \\
\hline F56 & Smilacina stellata & F97 & Senecio pauperculus \\
\hline F56 & Hieracium piloselloides & F97 & Danthonia spicata \\
\hline F56 & Senecio pauperculus & F97 & Panicum linearifolium \\
\hline F56 & Carex richardsonii & F97 & Rhus radicans \\
\hline F56 & Carex crawei & $\overline{\text { F97 }}$ & Solidago spp. \\
\hline$\overline{F 56}$ & Unknown species & F97 & Hieracium piloselloides \\
\hline 661 & 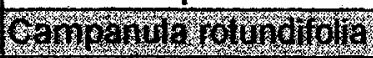 & F97 & Scutellaria parvula \\
\hline F64 & Solidago nemoralis & F97 & Carex richardsonii \\
\hline$\overline{F 64}$ & Carex crawei & F97 & Sporobolus vaginiflorus \\
\hline F64 & Hieracium piloselloides & F97 & Isanthus brachiatus \\
\hline F64 & Scutellaria parvula & F97 & Comandra umbellata \\
\hline F64 & Smilacina stellata & & \\
\hline F64 & Sporobolus vaginiflorus & & \\
\hline F64 & Senecio pauperculus & & \\
\hline F64 & Trifolium aureum & & \\
\hline
\end{tabular}




\section{Appendix E: Number of Species by plot in the Vegetation Survey and the Soil Seed Bank Study}

\begin{tabular}{|c|c|c|c|c|c|}
\hline 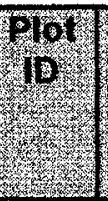 & 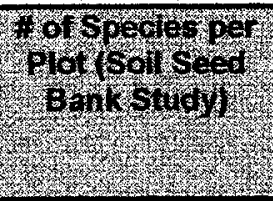 & 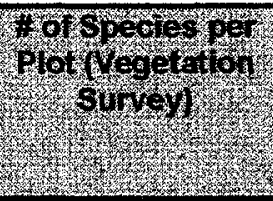 & Port & 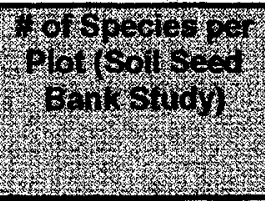 & of \\
\hline A33 & 7 & 8 & DO & 8 & 5 \\
\hline A37 & 8 & 16 & D4 & 8 & 11 \\
\hline A43 & 7 & 5 & D8 & 4 & 9 \\
\hline A49 & 2 & 8 & D10 & 3 & 12 \\
\hline A60 & 6 & 11 & D50 & 5 & 9 \\
\hline A61 & 7 & 8 & D84 & 6 & 8 \\
\hline A62 & 6 & 9 & D85 & 4 & 6 \\
\hline A70 & 7 & 7 & D86 & 6 & 6 \\
\hline A89 & 8 & 11 & D95 & 4 & 9 \\
\hline A97 & 7 & 8 & D96 & 8 & 5 \\
\hline B22 & 7 & 10 & E22 & 4 & 7 \\
\hline B23 & 13 & 13 & E23 & 4 & 7 \\
\hline B38 & 5 & 10 & E34 & 6 & 9 \\
\hline B41 & 5 & 10 & E55 & 5 & 10 \\
\hline B58 & 10 & 12 & E56 & 2 & 8 \\
\hline B60 & 11 & 4 & E63 & 6 & 10 \\
\hline B61 & 12 & 11 & E71 & 5 & 11 \\
\hline B78 & 8 & 13 & E78 & 2 & 7 \\
\hline $\mathrm{B89}$ & 8 & 8 & E81 & 3 & 10 \\
\hline B93 & 7 & 17 & E98 & 2 & 13 \\
\hline $\mathrm{CO}$ & 8 & 12 & $\mathrm{~F} 7$ & 4 & 8 \\
\hline $\mathrm{C} 10$ & 9 & 11 & F16 & 6 & 9 \\
\hline C11 & 9 & 10 & F20 & 4 & 9 \\
\hline C14 & 2 & 8 & F36 & 4 & 6 \\
\hline $\mathrm{C} 25$ & 2 & 9 & F56 & 5 & 9 \\
\hline C30 & 2 & 7 & F64 & 6 & 10 \\
\hline C35 & 5 & 10 & F76 & 4 & 10 \\
\hline C51 & 5 & 9 & F79 & 5 & 9 \\
\hline C67 & 6 & 9 & F81 & 2 & 9 \\
\hline C88 & 1 & 5 & F97 & 7 & 14 \\
\hline
\end{tabular}




\section{Appendix F: Soil Depth by Plot}

\begin{tabular}{|l|l|l|l|}
\hline $\begin{array}{l}\text { Plot } \\
\text { ID }\end{array}$ & $\begin{array}{l}\text { Soil Depth } \\
(\mathrm{cm})\end{array}$ & Plot ID & $\begin{array}{l}\text { Soil Depth } \\
\text { (cm) }\end{array}$ \\
\hline A33 & 15 & D0 & 18 \\
\hline A37 & 14.8 & D4 & 20 \\
\hline A43 & 16.5 & D8 & 12 \\
\hline A49 & 10.2 & D10 & 12 \\
\hline A60 & 16.5 & D50 & 17 \\
\hline A61 & 14 & D84 & 27.5 \\
\hline A62 & 10 & D85 & 13 \\
\hline A70 & 10 & D86 & 11 \\
\hline A89 & 6.5 & D95 & 20 \\
\hline A97 & 10 & D96 & 27.5 \\
\hline B22 & 10 & E22 & 17 \\
\hline B23 & 13 & E23 & 14.5 \\
\hline B38 & 20 & E34 & 23 \\
\hline B41 & 17 & E55 & 11.5 \\
\hline B58 & 24 & E56 & 18 \\
\hline B60 & 5 & E63 & 14.5 \\
\hline B61 & 20 & E71 & 16 \\
\hline B78 & 16 & E78 & 14.5 \\
\hline B89 & 17 & E81 & 12.5 \\
\hline B93 & 11 & E98 & 16 \\
\hline C0 & 19 & F7 & 14 \\
\hline C10 & 20 & F16 & 14 \\
\hline C11 & 19 & F20 & 13 \\
\hline C14 & 15 & F36 & 17 \\
\hline C25 & 19 & F56 & 16 \\
\hline C30 & 16 & F64 & 13 \\
\hline C35 & 16 & F76 & 13 \\
\hline C51 & 18 & F79 & 13 \\
\hline C67 & 17 & F81 & 11 \\
\hline C88 & 19 & F97 & 11 \\
\hline & & \\
\hline
\end{tabular}

